\title{
Schuldsanering voor natuurlijke personen in Nederland
}

\author{
Frits Salomons*
}

\section{Inleiding}

Er zijn talloze mensen met schulden, zeer vele ook met problematische schulden. Dit is een probleem voor die mensen en voor hun schuldeisers, maar ook voor de samenleving. Het recht stelt de eigen verantwoordelijkheid van de schuldenaar voorop. Een schuld is een juridische verplichting die drukt op de schuldenaar. Hij is gehouden - verbonden - zijn schuld te voldoen. De grondslag voor deze norm behoeft hier niet verder te worden onderzocht.

De schuldenaar die tekortschiet in de nakoming van zijn verbintenissen, kan door de schuldeiser geconfronteerd worden met maatregelen. Als juristen beperken wij onze aandacht veelal tot rechtsmaatregelen. Deze kunnen gericht zijn op het prikkelen van de schuldenaar om zijn schuldeiser te voldoen: variërend van aanmaningen en ingebrekestellingen tot het instellen van vorderingen in rechte en de betekening van titels met bevelen tot betaling. Is het zover gekomen, dan ligt ook tenuitvoerlegging door beslaglegging en uitwinning voor de hand. Soms zijn er kortere wegen beschikbaar, hetzij rechtstreeks - door verrekening of door gebruikmaking van zekerheden (pand, hypotheek, borgen) - hetzij indirect via retentie- of opschortingsrechten. Bestaat er tussen schuldeiser en schuldenaar een contractuele verhouding, dan zal de schuldeiser deze in veel gevallen door opzegging of ontbinding beëindigen. Al deze maatregelen kenmerken zich hierdoor, dat zij niet per se 'maatwerk' opleveren: veelal brengen zij de schuldenaar extra nadeel boven de ermee afgedwongen voldoening van zijn schuld. ${ }^{\mathrm{I}}$ En zo kan de aanwezigheid van enige schulden bij niet-voldoening al snel uitlopen in een problematische schuldsituatie.

Zijn er meer schuldeisers die overgaan tot executiemaatregelen, dan krijgen de schuldeisers ook met elkaar te maken. Voor cumulatie van verhaalsbeslagen op bepaalde goederen bepaalt de wet dat de opbrengst tussen de schuldeisers wordt verdeeld, bij voorkeur in der minne (art. 480 lid 2 Wetboek van Burgerlijke Rechtsvordering ${ }^{2}$ ), zo nodig in een gerechtelijke procedure (rangregeling) ten overstaan van een rechter-commissaris (art. 48I e.v. Rv). Heeft de samenloop betrekking op ongelijksoortige aanspraken, zoals bij samenloop van een beslag tot afgifte met een

Frits Salomons is raadsheer bij het ministerie van Justitie.

I. Vgl. art. 6:265 lid I BW, dat ontbinding van wederkerige overeenkomsten in beginsel mogelijk maakt bij 'iedere tekortkoming'. Proportionaliteit wordt niet geëist, al mag het natuurlijk niet te gek worden ('tenzij de tekortkoming, gezien haar bijzondere aard of geringe betekenis, deze ontbinding met haar gevolgen niet rechtsvaardigt').

2. Hierna afgekort als: Rv. 
verhaalsbeslag, dan is het lastiger om tot een evenwichtige afwikkeling te komen (vgl. art. $497 \mathrm{Rv}$ ).

Als de positie van de schuldenaar zo benard wordt dat hij is komen te verkeren 'in de toestand van te hebben opgehouden te betalen', dan kunnen bijzondere rechtsmaatregelen worden getroffen. Dat is het terrein van het insolventierecht. Deze maatregelen liggen in het verlengde van het individuele executierecht: het faillissement komt naar de uitdrukkelijke bedoeling van de wetgever neer op een algeheel gerechtelijk beslag, gericht op een zo goed mogelijke voldoening van de gezamenlijke schuldeisers. In de opzet van de Faillissementswet ${ }^{3}$ is daarbij uitgegaan van een conservatoire fase, gericht op het inventariseren van de boedel en de schulden, welke fase kan uitlopen op een akkoord (maar dat meestal niet doet), en een executoriale fase als er geen akkoord tot stand komt en de boedel daarmee - zoals art. 173 lid I Fw het uitdrukt - in 'staat van insolventie' is komen te verkeren. In een groot deel van de faillissementen komt het zover niet, als gevolg van de omvang van de boedelschulden. Er vindt dan geen verdeling onder de failissementsschuldeisers plaats en het faillissement wordt opgeheven wegens gebrek aan baten. De surseance van betaling vormt een kwijnend voorportaal van faillissement, ondanks herhaalde pogingen van de wetgever (1925, I935, 2005) om er meer van te maken. Succesvolle surseances, dat wil zeggen niet uitmondend in faillissement, zijn uiterst zeldzaam.

Het faillissement vormt een gerechtelijk beslag, een mechanisme om de verhaalsaanspraken van de schuldeisers af te wikkelen. Het strekt derhalve, in de doelomschrijving van 'insolventieprocedure' in art. I.I.2 van het Voorontwerp-Insolventiewet, 'tot tegeldemaking van het vermogen van de schuldenaar en verdeling van de opbrengst onder de gezamenlijke schuldeisers' ${ }^{4}$ Maar wat heeft een faillissement de schuldenaar te bieden? Weinig, als het niet komt tot een akkoord. Voor rechtspersonen brengt de staat van insolventie of de opheffing wegens gebrek aan baten de ontbinding van de rechtspersoon mee (art. 2:I9 lid I onder c BW) en eindigt met de vereffening ook het bestaan van de rechtspersoon. Natuurlijke personen leven voort, mét het onvoldaan gebleven deel van hun schulden.

De wettelijke schuldsaneringsregeling strekt ertoe om natuurlijke personen een mogelijkheid te bieden zich te bevrijden van hun schuldenlast. Daartoe dient de schuldenaar zich gedurende een door de rechter te bepalen termijn van in beginsel drie jaar te onderwerpen aan een bijzonder insolventieregime. Zijn vermogen en al hetgeen hij, boven een door de rechter te bepalen vrij te laten bedrag, gedurende het regime verwerft, wordt aangewend ter bevrediging van zijn schuldeisers. De schuldenaar is verplicht zich in te spannen om zoveel mogelijk baten voor de boedel te verwerven. $\mathrm{Na}$ afloop van het schuldsaneringsregime kunnen zijn schulden niet langer worden afgedwongen, tenzij de rechter het regime op daartoe in de wet genoemde gronden voortijdig heeft beëindigd, dan wel aan het einde van de vastgestelde termijn heeft beslist dat de schuldenaar toerekenbaar is tekortgeschoten in de nakoming van zijn verplichtin-

3. Hierna afgekort als: Fw.

4. Waaraan is toegevoegd: 'of tot sanering van de schulden van de schuldenaar'. De toelichting vermeldt dat de belangen van de schuldeisers voorop staan. 
gen. Blijkt achteraf dat de schuldenaar zijn schuldeisers heeft trachten te benadelen, dan kan de rechter de afdwingbaarheid van de schulden doen herleven. ${ }^{5}$

\section{$2 \quad$ Plan van behandeling}

Op I6 oktober 2006 sprak mevrouw Noorman-den Uyl ter gelegenheid van de behandeling van wetsvoorstel 29942 tot wijziging van de Faillissementswet in verband met herziening van de schuldsaneringsregeling natuurlijke personen in de Tweede Kamer de volgende woorden: 'Nederland was het eerste land dat mensen met problematische schulden een kans bood op een schone lei. Later hebben andere Europese landen gekeken hoe Nederland dat deed. ${ }^{6}$

Hiermee overdreef mevrouw Noorman enigszins. ${ }^{7}$ De schuldsaneringsregeling natuurlijke personen is in werking getreden op I december $1998 .^{8}$ Frankrijk kende al sinds 1990 een regeling voor de sanering van schulden van particulieren, waarbij tot 2004 de nadruk evenwel niet lag op kwijtschelding maar op afbetaling, en ook de Scandinavische landen waren Nederland voorgegaan. ${ }^{9}$ Evenmin zal de Nederlandse regeling van invloed zijn geweest op de slechts één maand later in werking getreden Duitse Insolvenzordnung (die ook een mogelijkheid van Restschuldbefreiung kent) en de Belgische regeling betreffende de collectieve schuldregeling. Omgekeerd is ook de Nederlandse regeling minder geïnspireerd door Europese dan door Amerikaanse ontwikkelingen. ${ }^{\text {IO }}$ De schuldsaneringsregeling is dan ook vooral te beschouwen als één van de varianten waarin de uit Amerika overgewaaide fresh-startbenadering vorm heeft gekregen. Zowel in België als in Nederland is de regeling inmiddels door de wetgever min of meer ingrijpend herzien. Verdergaande herziening ligt in Nederland wellicht in het verschiet. Een uitstekend moment voor een vergelijking van beide regelingen!

5. Een omschrijving van de schuldsaneringsregeling vindt men ook bij H.H. Dethmers, 'De schuldsaneringsregeling processueel benaderd', Tijdschrift voor Civiele Rechtspleging 2007, p. 90-99, aldaar p. 90, en A. Noordam, Schuldsanering en goede trouw, diss. VU 2007, p. IO-I3.

6. Kamerstukken II 2006-2007, 29 942, nr. 35, p. 3.

7. Volgens Wessels is Nederland binnen Europa zelfs één van de laatste landen waar een wettelijke regeling inzake schuldsanering voor particulieren is ingevoerd (Polak-Wessels Insolventierecht, Deel IX, Schuldsaneringsregeling natuurlijke personen, Kluwer, I990, par. 90I6).

8. Koninklijk Besluit van 9 november 1998 , Stb. 1998,622 , houdende vaststelling van het tijdstip van inwerkingtreding van de Wet van 25 juni 1998 tot wijziging van de Faillissementswet in verband met de sanering van schulden van natuurlijke personen (Stb. I998, 445); Invoeringswet schuldsaneringsregeling natuurlijke personen (Stb. 1998, 446); Tweede invoeringswet schuldsaneringsregeling natuurlijke personen (Stb. I998, 448).

9. U. Reifner, 'Personal Bankruptcy Law and Inclusive Contract Law', in: J. Niemi-Kiesiläinen, I. Ramsay en W. Whitford (eds.), Consumer Bankruptcy in Global Perspective, Oxford and Portland, Oregon, 2003, p. I49-I50.

Io. Vgl. N.J.H. Huls, Van liquidatie tot rehabilitatie, Een beleidsgerichte verkenning naar de toepassingsmogelijkheden van het Amerikaanse faillissementsrecht voor particulieren (Ministerie van Economische Zaken, 1988). Het werk van Huls is van duidelijke invloed geweest op het rapport van de Commissie ter advisering omtrent eventuele herziening van de Faillissementswet (Commissie Mijnssen) uit oktober I989. In het rapport wordt op p. 277 behalve naar de Verenigde Staten verwezen naar wettelijke regelingen voor restschuldbevrijding voor natuurlijke personen in Engeland en Frankrijk, terwijl ook wordt ingegaan op Duitste wetgevingplannen ter zake. 
Een kader voor de vergelijking van de Belgische collectieve schuldregeling en de Nederlandse schuldsaneringsregeling natuurlijke personen is gezocht in een bijdrage van prof. De Groote aan de hoorzitting van 25 juni 2007 van de Section for Employment, Social Affairs and Citizenship van het Economic \& Social Committee met het oog op de redactie van het rapport Credit and social exclusion in an affluent society. In die bijdrage zijn enige 'basisprincipes voor curatieve maatregelen inzake consumer overindebtedness' ontwikkeld en verdedigd. ${ }^{\text {II }}$ Deze principes kunnen goed dienst doen als thematisch kader voor de beoordeling van de Nederlandse regeling, zowel in het licht van actuele voorstellen tot wijziging als in het licht van de Belgische regeling. ${ }^{12}$ Zij bieden enige ijkpunten voor een regeling voor de sanering van schulden van natuurlijke personen. Aanvankelijk wilde ik ook voor de indeling van deze verhandeling aanknopen bij de genoemde principes. Dat leverde echter geen bevredigende indeling op. Daarom geef ik de voorkeur aan een andere opzet, waarbij ik in paragraaf 3 eerst enige historische gegevens in herinnering roep en daarbij inga op de totstandkoming van de schuldsaneringsregeling, de ervaringen in de praktijk met de regeling en de inmiddels tot stand gebrachte aanpassingen. Vervolgens komt in paragraaf 4 de reeds van vóór de wettelijke regeling van de schuldsanering daterende praktijk van buitengerechtelijke schuldhulpverlening aan de orde. Eén van de uitgangspunten voor de Nederlandse wetgever is dat dit minnelijk traject (dat in het spraakgebruik wordt gesteld tegenover het wettelijk traject van de wettelijke schuldsaneringsregeling ${ }^{13}$ ) zoveel mogelijk dient te worden gestimuleerd. Een te groot succes - in kwantitatieve zin - van de wettelijke regeling vormt in zekere zin een bedreiging voor het minnelijk traject en doet daarmee afbreuk aan de doelstellingen van de wetgever. Als mogelijke remedie is vanuit de praktijk aangedrongen op wettelijke maatregelen om het minnelijke traject te 'versterken', zoals een moratorium van incasso- en executiemaatregelen en een dwangakkoord. ${ }^{\mathrm{I}}$ Het betoog wordt in paragraaf 5 vervolgd met een beschrijving van de procedures die deel uitmaken van de

II. Vgl. ook B. de Groote, 'De vernieuwde collectieve schuldenregeling: een stap vooruit? Aanzet tot evaluatie', in E. Terryn (ed.), Handboek consumentenkrediet, Brugge, Die Keure, 2007.

I2. De vergelijking met de Belgische regeling zal uiteraard vooral moeten worden gemaakt door vergelijking met het de beschouwingen van de preadviseurs De Groote en Voet.

I3. Dit 'wettelijke traject' wordt ook wel aangeduid als 'Wsnp', welke afkorting staat voor: Wet schuldsaneringsregeling natuurlijke personen. Deze aanduiding heeft iets oneigenlijks, nu de schuldsaneringsregeling een onderdeel vormt van de Faillissementswet (Fw) en dus geen zelfstandige wet. Gelet op de nogal stijve wettelijke terminologie, volgens welke de schuldenaar kan verzoeken 'de toepassing van de schuldsaneringsregeling uit te spreken', is het niet verwonderlijk dat doorgaans veelal wordt gesproken van 'toelating tot de Wsnp' of 'toelating tot de schuldsaneringsregeling'.

I4. Gedoeld wordt dan op de mogelijkheid van een regeling met de schuldeisers waarbij de instemming van één of enige der schuldeisers wordt vervangen door een beslissing van de rechter, en dit zonder dat de schuldenaar is toegelaten tot de schuldsaneringsregeling of failliet is verklaard. De term 'dwangakkoord' wordt ook gebezigd in andere betekenis, ter aanduiding van de mogelijkheid dat de rechter na verwerping door de schuldeisers van een akkoord dat is aangeboden in faillissement, in surseance of in de schuldsaneringsregeling, het akkoord niettemin vaststelt als ware het door de schuldeisers aangenomen, indien is voldaan aan de vereisten, omschreven in de artikelen I46, 268a, respectievelijk 332 lid 4 Fw. Ten slotte wordt de term 'dwangakkoord' mede gebruikt om aan te duiden dat ook bij het akkoord dat door stemming van de (daartoe gekwalificeerde) schuldeisers wordt aangenomen sprake is van 'dwang', nl. in die zin dat het akkoord ook verbindend is voor schuldeisers die daarmee niet hebben ingestemd. 
wettelijke schuldsaneringsregeling. Daarna wordt in paragraaf 6 nader ingegaan op de beoordeling die de rechter moet maken als om toelating tot de wsnp wordt verzocht, waaronder de goede trouw-toets. In paragraaf 7 komen de bevoegdheden van de bewindvoerder aan de orde, het door de rechter-commissaris uit te oefenen toezicht, alsmede de (beperkte) rol die schuldeisers spelen en de (eveneens beperkte) betekenis van preferenties. Paragraaf 8 is gewijd aan de crux van de regeling: de niet-afdwingbaarheid van restschulden, meestal aangeduid als schone lei. Enige van de voorstellen van de Commissie insolventierecht tot herziening van het insolventierecht komen aan de orde in paragraaf 9 . Ten slotte houdt paragraaf io een afsluitende beschouwing in.

\section{I De basisprincipes}

Het kader voor de beoordeling en vergelijking van de schuldsaneringsregeling wordt gevormd door in totaal negen basisprincipes:

I. Maatschappelijk belang

2. 'Fresh start'

3. Partij-autonomie

4. Rechterlijke betrokkenheid

5. Domino-effect

6. Inspanning van de schuldenaar

7. Redelijke termijn

8. Geen stigma

9. Kosten

Over elk van deze principes maak ik enige opmerkingen.

$1 \quad$ Maatschappelijk belang

Een uitgangspunt dat tegenwoordig algemeen ingang heeft gevonden, is dat er in de huidige maatschappij behoefte bestaat aan op natuurlijke personen toegesneden insolventieprocedures, waarbij de gevolgen van betalingsonmacht niet uitsluitend gedragen worden door de betrokken schuldenaren. Schulden zijn, zoals Huls het uitdrukt, van een privéprobleem tot een publiek vraagstuk geworden. ${ }^{15}$ Naar de regels van het verbintenissenrecht komt betalingsonmacht voor risico van de schuldenaar: tot de tekortkomingen die de schuldenaar niet kunnen worden toegerekend en hem op die grond niet schadeplichtig maken (artikel 6:75 BW), behoren niet die welke te wijten zijn aan geldelijk onvermogen. Tegelijkertijd wordt vrij algemeen onderkend dat onze maatschappij zich heeft ontwikkeld tot een consumptiemaatschappij, waarin kredietverlening een grote vlucht heeft genomen. De economische ontwikkeling van na de Tweede Wereldoorlog is mede bepaald door de acceptatie in brede kring van krediet. De overheid heeft daaraan bijgedragen door fiscale maatregelen (renteaftrek). Welvaart is daarvan het gevolg geweest, maar de keerzijde van

I5. N.J.H. Huls, Actie en reactie, Een inleiding in de rechtssociologie, Boom Juridische Uitgevers, Den Haag, 2008, p. 294. 
deze ontwikkeling is dat er aanzienlijke groepen zijn van mensen met een grote schuldenlast. Medio jaren negentig werd geschat dat bij ongeveer 150.000 tot 200.000 huishoudens in Nederland sprake was van een problematische schuldensituatie. Voor 2000 noemt Huls een aantal van 250.000 huishoudens. ${ }^{\text {I6 }}$ Jungmann verwijst naar onderzoek uit 1999, waaruit bleek dat een groep van 230.000 huishoudens te kampen heeft met een problematische betalingsachterstand, terwijl onderzoek uit 2004 onder huishoudens met een inkomen tot $150 \%$ van het bijstandsniveau uitkwam op 40.000 tot 90.000 huishoudens met een problematische schuldsituatie. ${ }^{17}$ Cijfers als deze zijn uiteraard sterk afhankelijk van de gehanteerde definities: bij vervolgonderzoek naar huishoudens met (risico op) problematische schulden bleek het niet mogelijk om 'de met het veld afgestemde definitie volledig op een betrouwbare wijze te operationaliseren'. ${ }^{18}$

Betalingsonmacht van schuldenaren is een zo veelvuldig voorkomend verschijnsel, dat de overheid zich wegens de daarmee gepaard gaande sociale kosten - armoede, sociale uitsluiting - gehouden acht tot een 'herverdeling' van de gevolgen. Niet slechts de schuldenaar draagt de (volledige) last van zijn schulden, maar ook de schuldeisers. Daarnaast draagt ook de overheid bij, door middel van diverse vormen van schuldhulp, saneringskredieten en het instandhouden van een wettelijke schuldsaneringsprocedure.

Met het invoeren van de wettelijke schuldsaneringsregeling voor natuurlijke personen erkent de wetgever het maatschappelijk belang om schuldenaren in problemen te hulp te schieten. Twee opmerkingen zijn in dit verband nog van belang. In de eerste plaats heeft bij de hiervoor bedoelde 'herverdeling' in Nederland een belangrijke rol gespeeld in hoeverre eisen moeten worden gesteld aan de 'goede trouw' van de schuldenaar. Dat dit aspect in elk geval een zekere rol moet spelen, om te voorkomen dat de regeling misbruikt kan worden ter benadeling van schuldeisers, zal door weinigen betwist worden. Het gevaar is echter niet denkbeeldig dat de eis teveel nadruk krijgtal dan niet vanuit de gedachte dat de schuldenaar niet zozeer een 'recht' heeft om de sanering van zijn schulden te 'verdienen', maar dat het gaat om een 'gunst', voorbehouden aan schuldenaren die dit 'waard' zijn. Verscherping van de eisen die aan schuldenaren worden gesteld, roept dan de vraag op wat de maatschappelijke gevolgen zijn voor de - aanzienlijke - groep schuldenaren die niet aan deze scherpere eisen kunnen voldoen. De Commissie insolventierecht, ingesteld om regering en parlement te adviseren over herziening van het insolventierecht, heeft met betrekking tot de in 2008 aangebrachte wijzigingen in de regeling benadrukt 'dat een beperking van de instroom in de wettelijke schuldsaneringsregeling geen oplossing biedt voor het

I6. Huls, Actie en reactie, p. 304 .

17. Jungmann, De Wsnp: bedoelde en onbedoelde effecten op het minnelijk traject (proefschrift), Leiden University Press, 2006, p. 45-46. De laatste cijfers lijken gunstiger, maar verschillen in de gehanteerde definities zullen daarbij een rol spelen.

I8. Aldus de Staatssecretaris van Sociale Zaken en Werkgelegenheid in een brief van 26 maart 2007 aan de Tweede Kamer (Kamerstukken II 2006-2007, 24 515, nr. Ioo, p. 6. In een brief van I9 oktober 2007 aan de Tweede Kamer wordt wel geconstateerd dat 'de schuldenproblematiek in Nederland de laatste jaren fors is toegenomen' (Kamerstukken II 2007-2008, 24 5I5, nr. II9, p. I). Noordam leidt uit door hem besproken gegevens uit 2005 af dat $2 \%$ à $3 \%$ van de Nederlandse huishoudens zich in een problematische schuldensituatie bevindt (Noordam, Schuldsanering en goede trouw, p. 58). 
bestaande maatschappelijke probleem dat een steeds groter wordende groep mensen in financiële problemen raakt. Beperking van de toegang tot de schuldsaneringsregeling zonder tevens andere maatregelen te nemen zal er slechts toe leiden dat een toenemend aantal mensen niet in staat zal zijn zich op enig moment te ontworstelen aan de hen overweldigende schuldenlast.' ${ }^{\text {I9 }}$

In de tweede plaats is van belang of de regeling beperkt dient te zijn tot consumenten of dat zij mede betrekking dient te hebben op natuurlijke personen die een onderneming drijven. Waar ondernemers uiteraard steeds óók consumenten zijn, lijkt er geen reden om deze categorie uit te sluiten van de regeling. Wel zouden in het aan ondernemen inherente risico-element argumenten kunnen worden gevonden om deze risico's voor rekening van de ondernemer te laten. De motie van het kamerlid Biesheuvel c.s., die de directe aanleiding vormde tot het ontwerpen van de wettelijke schuldsaneringsregeling, had slechts betrekking op 'privé-personen, niet ondernemer zijnde'. ${ }^{20}$ De Belgische collectieve schuldregeling is niet van toepassing op kooplieden (deze kunnen evenwel op grond van artikel 8o van de Belgische Faillissementswet wèl van hun restschulden worden bevrijd). ${ }^{2 I}$

$2 \quad$ 'Fresh start'

Het tweede basisprincipe is het principe van de 'fresh start'. Als gevolg van zijn schuldenlast is de schuldenaar veelal uitgesloten van een normaal maatschappelijk functioneren ('sociale uitsluiting'). Insolventieprocedures voor natuurlijke personen moeten daarom gericht zijn op de sociaal-economische re-integratie van de betrokken personen. De nadruk ligt daarbij niet meer uitsluitend (of primair) op het liquideren van de, doorgaans schamele, boedel ten behoeve van de schuldeisers, maar op het oplossen van de financiële problemen van de betrokkene. Deze benadering is in hoge mate op de toekomst gericht.

Men kan in het 'fresh start'-principe zonder overdrijving een nieuw paradigma zien. Op fraaie wijze komt dit in de Belgische regeling voor collectieve schuldregeling tot uitdrukking, waar in artikel $1675 / 3$, derde alinea, als strekking wordt geformuleerd: 'de financiële toestand van de schuldenaar te herstellen, met name hem in staat te stellen in de mate van het mogelijke zijn schulden te betalen en tegelijkertijd te waarborgen dat hij zelf en zijn gezin een menswaardig leven kunnen leiden'. Door het begrip 'menswaardig leven' wordt zelfs een verband gelegd met artikel 23 Grondwet (menswaardig bestaan). In de Nederlandse wet is geen doelbepaling opgenomen bij de schuldsaneringsregeling. Wel is in de voorbereidende stukken als hoofddoel van de regeling vermeld dat 'kan worden tegengegaan dat een natuurlijke

I9. Brief van 2 februari 2004 van de voorzitter van de Commissie insolventierecht aan de Minister van Justitie. De brief kan gevonden worden op: www.justitie.nl/onderwerpen/wetgeving/over_wetgeving/privaatrecht/commissies-privaatrecht/commissie-insolventierecht.aspx.

20. Kamerstukken II I988/89, I7 897, nr. I9.

2I. Huls, Van liquidatie tot rehabilitatie, vermeldt op p. 2 dat in Amerika kwijtschelding van schulden historisch eerder acceptabel werd gevonden bij zakenlieden, omdat de eisen van de handel met zich meebrachten dat zij niet onbeperkt aansprakelijk behoorden te zijn voor hun schulden. Voor consumenten vond de aanvaardbaarheid van kwijtschelding pas later ingang, mede op grond van overwegingen van gelijke behandeling (p. Io). 
persoon die in een problematische financiële situatie is terechtgekomen, tot in lengte van jaren met zijn schulden achtervolgd kan worden' ${ }^{22}$

In artikel I.I.2 van het Voorontwerp-Insolventiewet worden de doelen van de voorgestelde insolventieprocedure als volgt omschreven: 'Een insolventieprocedure strekt tot tegeldemaking van het vermogen van de schuldenaar en verdeling van de opbrengst onder de gezamenlijke schuldeisers of tot sanering van de schulden van de schuldenaar. Heeft de schuldenaar een onderneming, dan wordt deze zoveel als mogelijk behouden.' In de toelichting (Algemeen, onder 7) wordt uiteengezet dat het belang van de schuldeisers 'voorop dient te staan'. Direct daarvoor is vermeld dat het Voorontwerp geen uitvloeisel is van nieuwe theorieën, ${ }^{23}$ hetgeen overigens een echo is van een opmerking in de memorie van toelichting bij de oude Faillissementswet. ${ }^{24}$ Door Huls - zijn naam valt vaak - is bezwaar aangetekend tegen het voorgestane primaat van de schuldeisers, omdat de Commissie insolventierecht daarmee de 'fresh start'-gedachte zou miskennen. ${ }^{25}$ Hoewel ik de in het Voorontwerp voorgestelde regeling voor natuurlijke personen in diverse opzichten een verbetering acht, ${ }^{26}$ had best wat meer nadruk gelegd mogen worden op de 'fresh start'gedachte. Als het gaat om beslissingen die de boedel raken, mogen de belangen van de schuldeisers inderdaad vooropstaan. Als het er echter om gaat welke inspanningen van de schuldenaar gevergd mogen worden, of welk bedrag ter vrije besteding aan de schuldenaar moet worden gelaten, behoeft het schuldeisersbelang niet doorslaggevend te zijn - en wat mij betreft zelfs niet voorop te staan.

Het tweede basisprincipe omvat de gedachte dat kwijtschelding van schulden nodig kan zijn voor re-integratie van de schuldenaar, maar wel afhankelijk dient te zijn van een - gelet op de menselijke waardigheid van de schuldenaar en zijn gezin maximale betalingsinspanning door de schuldenaar. In het begrip 'menselijke waardigheid' herkent men het reeds genoemde artikel 23 van de Grondwet van België, een formulering met meer zeggingskracht dan zoiets als 'in overeenstemming met de omstandigheden van de schuldenaar en zijn gezin'. Hoewel ik het element van een maximale betalingsinspanning graag onderschrijf, is het niet vanzelfsprekend. Zo kent de Amerikaanse Chapter 7 procedure (in tegenstelling tot Chapter I3) wél kwijtschelding van schulden, maar staat daartegenover slechts liquidatie van het vermogen van de schuldenaar.

In het 'fresh start'-principe past voorts dat de schuldenaar zich onderwerpt aan begeleidende maatregelen om de duurzaamheid van zijn re-integratie te bevorderen. De schuldenaar zal immers in veel gevallen moeten leren beter met zijn geld om te

22. Kamerstukken II 1992/93, 22 969, nr. 3, p. 6.

23. Geschiedenis van de Faillissementswet, Voorontwerp Insolventiewet (red. S.C.J.J. Kortmann en N.E.D. Faber), Serie Onderneming en Recht deel 2-IV, Deventer 2007, p. I36. Het Voorontwerp met toelichting kan ook worden gedownload van de website van het ministerie van Justitie: www.justitie.nl/images/VoorontwerpInsolventiewet_tcm34-87549_tcm34-90173.pdf.

24. Men zie Kortmann/Faber, Geschiedenis van de Faillissementswet, heruitgave Van der Feltz, I, Zwolle ig84, p. 7.

25. N.J.H. Huls, 'Het Kortmann-uniform past de schuldsanering niet', in: J.A. van de Hel, M.C.A. van den Nieuwenhuizen en J.H. Verdonschot (red.), Het Voorontwerp Insolventiewet nader beschouwd, Ars Aequi Libri, Nijmegen, 2008, p. 27I-28I, aldaar p. 274.

26. Overigens heb ik als secretaris van de Commissie insolventierecht betrokkenheid gehad bij het Voorontwerp. 
gaan. Omgekeerd zou men hieraan de gevolgtrekking kunnen verbinden dat als op voorhand duidelijk is dat een re-integratie te geringe kans van slagen heeft, van de route van schuldsanering wordt afgezien. In dat licht kan men de wijzigingen zien die in 2008 zijn aangebracht in de schuldsaneringsregeling, voor zover deze erop gericht waren de toegang tot de regeling te beperken tot schuldenaren die 'er klaar voor zijn'. ${ }^{27}$

De re-integratie van de schuldenaar zal niet ten koste van alle schuldeisers hoeven te gaan. Een volledig 'nieuwe ronde, nieuwe kansen!' wordt nergens aanvaard. Bepaalde schulden verliezen ook na het succesvol doorlopen van de schuldsaneringsregeling hun afdwingbaarheid niet. Bij invoering in 1998 kende de Nederlandse schone lei in vergelijking met die in andere landen weinig uitzonderingen. In 2008 zijn er enige uitzonderingen bijgekomen. Nagegaan zal moeten worden welke overwegingen daarbij een rol hebben gespeeld.

\section{3}

\section{Partij-autonomie}

Oplossingen op basis van eigen keuzen van de betrokken partijen verdienen de voorkeur, zowel uit oogpunt van doelmatigheid als omdat deze een meer integrale benadering kunnen bevorderen. In dit derde basisprincipe herkent men voor de Nederlandse situatie de door de overheid sterk beleden wens om het minnelijk traject te stimuleren. Toch kan men zich daarbij niet aan de indruk onttrekken dat de overheid slechts beperkt vertrouwen stelde in het vermogen van betrokkenen om zelfstandig te komen tot de beste oplossingen. In de woorden van de Commissie Mijnssen uit I989:

\footnotetext{
'Van een wettelijke regeling zou juist ook een stimulerende invloed op de schuldeisers kunnen uitgaan om ten gunste van de schuldenaar een minnelijk accoord te treffen. Immers de wetenschap dat bij het niet tot stand komen van een regeling in onderling overleg, via het van toepassing verklaren van een wettelijke regeling een resultaat met dezelfde strekking kan worden bereikt, zal de bereidheid bevorderen om met hun schuldenaar een accoord te treffen, mede omdat het gebrek aan bereidheid niet altijd op zakelijke gronden berust maar op, misschien op zichzelf begrijpelijke, emotionele gronden. ${ }^{28}$
}

De wet moet hier fungeren - zoals men het is gaan uitdrukken - als een 'stok achter de deur'. Hoewel betrokkenen in beginsel de vrijheid behouden om wel of niet mee te werken aan de totstandkoming van een minnelijke regeling, worden de omstandigheden waaronder daarover moet worden beslist, soms verregaand door overheidsmaatregelen bepaald. Daar tekent zich dan ook een dilemma af: hoe ver kan het minnelijk traject worden gestimuleerd, zonder zelf een wettelijk traject te worden? Door sommigen is (en wordt) gepleit voor het 'versterken' van het minnelijk traject door middel van een moratorium voor verhaalsmaatregelen. De in artikel $287 \mathrm{~b} \mathrm{Fw}$ opgenomen mogelijkheid van bepaalde voorlopige voorzieningen voor een maxi-

27. Kamerstukken II 2004-2005, 29 942, nr. 3, p. I.

28. Rapport Commissie Mijnssen, p. 234-235. 
male duur van zes maanden ter mogelijke vermijding van toepassing van de wettelijke schuldsaneringsregeling, vormt daartoe een aanzet. De kunst is om hier een evenwicht te vinden, waarbij de beperkingen die aan schuldeisers worden opgelegd niet tot gevolg hebben dat de schuldenaar zijn financiële mogelijkheden te gemakkelijk kan inzetten voor andere doeleinden dan zo goed mogelijke aflossing van zijn schulden. Ook hoort men geluiden dat er verdere ruimte moet worden geschapen voor 'dwangakkoorden'. ${ }^{29}$ Naarmate het element van dwang echter toeneemt, zal de veronderstelde hogere effectiviteit van minnelijke regelingen meer op de achtergrond raken.

\section{$4 \quad$ Rechterlijke betrokkenheid}

Het vierde basisprincipe houdt in dat er ruimte dient te zijn voor rechterlijke betrokkenheid, waar schuldenaar en schuldeisers er niet in slagen in der minne tot een regeling te komen. Dit principe sluit daarmee logisch aan op het vorige. Rechterlijke betrokkenheid impliceert in dit verband dat partijen zich ook naar het daarmee gepaard gaande regime moeten richten, dat individuele tenuitvoerleggingen een einde nemen en dat uitkeringen aan schuldeisers, zo die plaatsvinden, in beginsel geschieden met inachtneming van de paritas creditorum. ${ }^{30}$

Dat de schuldsaneringsregeling aan het hier bedoelde basisprincipe beantwoordt, ligt voor de hand. Interessanter is de vraag of zij niet een te grote rechterlijke betrokkenheid vergt. Enige jaren na de invoering klonken uit de rechterlijke macht noodsignalen dat de insolventiekamers dreigden te verstoppen als gevolg van de aantallen en de bewerkelijkheid van schuldsaneringszaken. De wijzigingen die op I januari 2008 in werking zijn getreden, zijn in sterke mate ingegeven door deze signalen. In enige opzichten is de taak voor de rechter verlicht. Sedertdien tekent zich een sterke daling af van de toelatingen tot de schuldsaneringsregeling. ${ }^{\text {I }}$ Volgens Jongeneel, insolventierechter bij de rechtbank te Amsterdam, heeft de rechterlijke macht inmiddels weer voldoende greep op de schuldsaneringszaken: 'De machine draait.' ${ }^{22}$ In het Voorontwerp-Insolventiewet wordt de verhouding tussen het gerechtelijke en het buitengerechtelijke traject op andere wijze benaderd. Kort gezegd hoeven de inspanningen die van de schuldenaar worden verlangd ter verkrijging van zijn schone lei, niet meer geheel plaats te vinden gedurende de insolventieprocedure. Ook inspanningen ten behoeve van de schuldeisers, voorafgaand aan of aansluitend op de insolventieprocedure, kunnen meetellen. Of het verantwoord is om de rechterlijke betrokkenheid op deze wijze terug te dringen, is één van de vragen die naar aanleiding van het Voorontwerp zullen moeten worden overwogen.

29. Bijvoorbeeld Dethmers, 'De schuldsaneringsregeling processueel benaderd', p. 98 .

30. Het 'in beginsel' biedt uiteraard ruimte om rekening te houden met wettelijke gronden voor voorrang.

3I. Een causaal verband ligt voor de hand, maar opmerkelijk genoeg doet zich een vergelijkbare daling voor in het aantal faillissementen van natuurlijke personen.

32. R.H.C. Jongeneel, 'Het voorontwerp voor een nieuwe Insolventiewet (2), De inspanningstermijn na insolventie', Schuldsanering, 2008/3, p. 15-17, aldaar p. I6. Hij voegt daaraan wel toe: 'Wel is een voortdurend punt van aandacht dat de gerechtsbesturen voldoende capaciteit voor de insolventie-afdelingen moeten (blijven) inzetten.' 


\section{Domino-effect}

Rekening moet worden gehouden met een mogelijk domino-effect, wanneer de insolventie van een natuurlijke persoon ook andere personen in moeilijkheden brengt, die zekerheid hebben gesteld of zich sterk hebben gemaakt voor die persoon. Anders dan in België is dit principe in de Nederlandse regeling met zoveel woorden afgewezen (artikel $300 \mathrm{Fw}$ ): 'De schuldsaneringsregeling werkt niet ten voordele van borgen en andere medeschuldenaren.' Ter toelichting stelde de regering zich op het standpunt dat 'het uitgangspunt dat de schuldsaneringsregeling een regeling beoogt te geven voor een natuurlijke persoon die in een problematische schuldensituatie is geraakt of draagt te geraken, met zich meebrengt dat de toepassing steeds een individuele schuldenaar betreft'. En zij vervolgde: 'Dit betekent ook dat andere personen die met de schuldenaar (...) voor schulden zijn verbonden, (...) niet uit die gebondenheid zijn ontslagen of anderszins van het van toepassing zijn van de regeling zouden moeten kunnen profiteren.' 33 Of dit een dwingende redenering oplevert, weet ik niet zeker. Wel zou ik menen dat borgstellingen naar hun aard vooral bedoeld zijn om effect te sorteren als de hoofdschuldenaar niet meer kan betalen. Bevrijding van de borg ligt daarom in de schuldsaneringsregeling niet méér voor de hand dan in geval van faillissement, zeker niet als men ervan uitgaat dat in de schuldsaneringsregeling ten behoeve van de schuldeisers niet slechts liquidatie van de boedel van de schuldenaar plaatsvindt, maar bovendien gedurende een langere tijd het surplus van zijn verdiencapaciteit exclusief wordt bestemd voor deze schuldeisers (met uitsluiting van nieuwe schuldeisers). Artikel $300 \mathrm{Fw}$ is in Nederland niet omstreden.

$6 \quad$ Inspanning van de schuldenaar

Het zesde basisprincipe houdt in dat de schuldenaar voor de (gehele of gedeeltelijke) bevrijding van zijn restschulden een passende financiële inspanning dient te leveren, gelet op zijn menselijke waardigheid. Voor wat hoort wat, derhalve. Schuldeisers kunnen door de inspanningen van de schuldenaar nog een deel van hun vorderingen voldaan krijgen. Twee kanttekeningen zijn hier op zijn plaats. Ten eerste zijn er schuldenaren van wie in het geheel niet valt te verwachten dat zij enig bedrag aan hun schuldeisers zullen kunnen voldoen. Dit zou niet in de weg moeten staan aan een schone lei, nu het belang daarbij voor de schuldenaar onverminderd groot is en voor de schuldeisers het verschil tussen een geringe betaling, hoe klein ook, en in het geheel geen betaling niet zodanig is, dat dit onthouding van een schone lei zou kunnen rechtvaardigen. Ten tweede mag van de schuldenaar ook een andere dan financiële inspanning worden verlangd. Bevrijding van schulden heeft weinig zin zonder het vooruitzicht dat de schuldenaar zijn inkomsten en uitgaven in balans kan houden. De schuldenaar zal daarom bereid moeten zijn zich aan budgetbegeleiding of budgetbeheer te onderwerpen. Door te laten zien dat het risico van nieuwe schuldproblemen zoveel mogelijk onder controle is, 'verdient' hij een schone lei. Deze opvatting betekent niet dat de schone lei moet worden beschouwd als een 'gunst' aan de schuldenaar. Ook als men de mogelijkheid van schuldsanering

33. Kamerstukken II I992/93, 22 969, nr. 3 (memorie van toelichting), p. I8. 
beschouwt als iets waarop de schuldenaar aanspraak kan maken, zou het zinloos zijn die aanspraak ook te erkennen in omstandigheden waar het risico van nieuwe schuldproblemen onverminderd aanwezig is.

\section{$7 \quad$ Redelijke termijn}

Als zevende basisprincipe geldt dat waar de schone lei afhankelijk is van een financiele inspanning gedurende een zekere periode, deze periode redelijk dient te zijn. Er kan van uitgegaan worden dat het niet goed mogelijk is om gedurende te lange tijd verantwoord rond te komen van een (sub)minimaal inkomen. Een te lange inspanningsperiode zal daarom niet effectief zijn en de kans verkleinen op succesvolle maatschappelijke re-integratie van de schuldenaar. De schuldsaneringsregeling gaat uit van een duur van drie jaar, welke in bijzondere gevallen kan worden verlengd tot maximaal vijf jaar. Bij de totstandkoming van de regeling is uitvoerig gediscussieerd over de vraag of het voor schuldenaren wel mogelijk zou zijn om vijf jaar op een minimaal inkomen te leven. ${ }^{34}$ In gevallen dat redelijkerwijs niet verwacht wordt dat de schuldenaar boven hetgeen hij voor zijn eigen levensonderhoud nodig heeft, nog iets voor zijn schuldeisers zal overhouden, kan de toepassingsduur van de regeling worden bekort tot één jaar (art. 354a Fw).

8

Geen stigma

Ten achtste zou de schuldenaar na de bevrijding van zijn restschulden geen beperkingen op grond van zijn verleden dienen te ondervinden. De schuldenaar zou wederom onbelemmerd toegang moeten krijgen tot de financiële markt. Negatieve signaleringen in kredietregistratiesystemen zouden moeten worden doorgehaald. Over dit onderwerp kan men gemakkelijk anders denken. Waar veel schuldenaren in problemen raken door overcreditering, is er veel voor te zeggen om bij deze groep na een geslaagde schuldsanering verdere blootstelling aan dit risico te beperken. Ook van belang is de nadruk die tegenwoordig wordt gelegd op de zorgplicht van financiele dienstverleners om te voorkomen dat hun cliënten onverantwoorde financiële verplichtingen aangaan. Dit onderstreept eerder het belang van een goede registratie van schulden, dan dat de schone lei werkelijk een tabula rasa zou moeten zijn. Hoe dat ook zij, dit onderwerp maakt als zodanig geen deel uit van de schuldsaneringsregeling en zal om die reden in het navolgende geen bijzondere aandacht krijgen.

\section{$9 \quad$ Kosten}

Het negende basisprincipe houdt in dat de kosten van de insolventieprocedure voor de schuldenaar geen belemmering mogen vormen om daarvan gebruik te maken. Voor wat de toelating tot de schuldsaneringsregeling betreft, is van belang dat de schuldenaar het verzoek hiertoe kan indienen zonder verplichte tussenkomst van een advocaat (art. 36r Fw) en hij daarvoor geen griffierecht is verschuldigd (art. I5 lid

34. Dit heeft ertoe geleid dat bij amendement is vastgelegd dat als de rechter de duur op vijf jaar zou vaststellen, voor de gehele vijfjaarsperiode boven de beslagvrije voet een extra deel van het inkomen van de schuldenaar zou worden vrijgelaten (thans art. 349a lid I, tweede zin, Fw). In de praktijk wordt in alle gevallen - dus ook als niet wordt afgeweken van de gewone duur - een bedrag boven de beslagvrije voet vrijgelaten. 
I Wet tarieven in burgerlijke zaken). De vergoeding voor de bewindvoerder - die vaak geen advocaat is - behoeft voorts niet volledig uit de boedel te worden voldaan: naast het salaris ten laste van de boedel (art. $320 \mathrm{Fw}$ ) kan de bewindvoerder aanspraak maken op een vergoeding op grond van het Besluit subsidie bewindvoerder schuldsanering, dat zijn grondslag heeft de artikelen $48 \mathrm{c}$ en $48 \mathrm{~d}$ van de Wet justitie-subsidies. Mede omdat deze subsidiëring de balans tussen het minnelijke en het wettelijke traject ten nadele van het eerste kan beïnvloeden, bestaat het voornemen om de subsidie te beperken in zaken waar de vergoeding van de bewindvoerder volledig uit de boedel kan worden voldaan.

\section{Een beetje geschiedenis}

Met de inwerkingtreding van de Faillissementswet in I896 liep de wetgever voor het insolventierecht vooruit op de opheffing van het onderscheid tussen kooplieden en niet-kooplieden (in 1934). Voordien kende het Nederlandse insolventierecht sinds de codificatie van 183835 voor kooplieden het faillissement en voor particulieren (en andere niet-kooplieden) de 'staat van kennelijk onvermogen'.

\section{I De wetgeving van $18{ }_{3} 8$}

De regeling van het faillissement in het Wetboek van Koophandel van 1838 leverde in de praktijk een aantal knelpunten op. Bij een bespreking door de Nederlandsche Juristen-Vereeniging in I87I bleek dat o.m. de rechtstoestand van de failliet en de schuldeisers na afloop van de vereffening verbetering behoefde. Onduidelijkheid bestond erover, in hoeverre de schuldenaar wederom zelf aan het rechtsverkeer kon deelnemen. ${ }^{36}$ Schuldeisers behielden na vereffening van de boedel en uitdeling van de opbrengst het onvoldaan gebleven deel van hun vorderingen, maar onduidelijk was of zij dit wederom door beslag en tenuitvoerlegging konden verhalen, dan wel om heropening van het faillissement moesten verzoeken. Rechtsonzekerheid voor alle betrokkenen was het gevolg.

35. Daarvóór gold hier het Franse recht, waaraan het onderscheid tussen kooplieden en niet-kooplieden is ontleend. Zie Noordam, Schuldsanering en goede trouw, p. I97. In het voorbijgaan vermeld ik de Amsterdamse Ordonnantie voor de Kamer der Desolate Boedels uit 1777, die een regeling kende voor rehabilitatie met ontslag van restschulden. Deze rehabilitatie kon door de niet te kwader trouw gehandeld hebbende schuldenaar worden verkregen met instemming van 5/8 van de schuldeisers, vertegenwoordigende meer dan de helft van de schuldeisers. Meer gegevens hierover vindt men bij Noordam, Schuldsanering en goede trouw, p. I69-172.

36. Vgl. de volgende opmerkingen van één van de aanwezigen bij de NJV-vergadering: 'Iemand wordt failiet en insolvent verklaard. Later begint hij een nieuwe zaak. Het faillissement en de insolventie zijn vergeten. Er zijn een aantal menschen, die vroeger insolvent zijn verklaard en later groote zaken doen. Op de kermis kan men ze zien. Doch niet ieder koopman weet wie al of niet insolvent is verklaard, vooral wanneer dit is geschied voor vele jaren en in eene andere gemeente. Het is moeilijk een register aan te leggen van alle insolventverklaarde kooplieden. Met zoodanig persoon worden dus contracten gesloten, hetgeen aanleiding kan geven tot een geschil en eene dagvaarding; hij is, meent men, een "persona standi in iudicio". Maar omdat hij vroeger insolvent is verklaard, zegt hij zelf: ik kan als beheerder van eigen goederen niet in rechte optreden' (Handelingen der NJV I87I, p. I29). 
Voor niet-kooplieden was in 1838 een regeling getroffen betreffende de 'staat van kennelijk onvermogen' (déconfiture). Niet iedereen had een dergelijke regeling nodig gevonden. Maar hoewel bij niet-kooplieden belangen van zakelijke kredietverleners niet in het geding waren, onderkende men dat ook in particuliere kringen kredietverlening niet afwezig was en de wet ook hier de paritas creditorum diende te beschermen. ${ }^{37}$ De in vergelijking met het faillissement veel beperktere toelatingsgronden hielden verband met het feit dat men het faillissement beschouwde als een regeling ter begunstiging van de koophandel, waarbij voldoende was dat de schuldenaar bij zijn aangifte verklaarde opgehouden te hebben met betalen. Bij niet-kooplieden diende de betalingsonmacht tot uitdrukking te komen in feitelijkheden als langdurige gijzeling, gelijktijdige executoriale beslagen of heimelijk vertrek van de schuldenaar 'zonder orde op zijne zaken gesteld te hebben' (art. 883 Rv I838). Dat de wetgever de financiële problemen van de schuldenaar die geen koopman is, veel meer aan schuld en kwade trouw wijt, verklaart dat voor het aannemen van een akkoord een veel grotere meerderheid van de schuldeisers vereist is. ${ }^{38}$ Voor het overige waren er weinig verschillen met de regeling van faillissement. 39

Vermelding verdient nog dat naast de regeling van kennelijk onvermogen voor de 'ongelukkigen en te goeder trouw gehandeld hebbende schuldenaar' ook de mogelijkheid openstond om bij wijze van 'gunst' boedelafstand te verzoeken. Door boedelafstand werden al zijn goederen ten behoeve van zijn schuldeisers uitgewonnen, doch werd de schuldenaar wel ontslagen van lijfsdwang (art. 707, $709 \mathrm{Rv}$ I838). ${ }^{40}$ Boedelafstand werd slechts zelden toegepast. ${ }^{4 \mathrm{I}}$

37. Blijkens het volgende citaat uit de weergave van de parlementaire geschiedenis bij J.J. de Vries, Het kennelijk onvermogen (burgerlijk faillissement) volgens Nederlandsch recht en buitenlandsche wetgevingen, Diss., Amsterdam, I870: 'En is er nu eenmaal door verschillende personen krediet verleend, dan ontstaat er gelijkheid van positie en gelijkheid van recht; moge het krediet in het gewone leven ook al niet, zooals in den handel, het rad zijn, dat alles in beweging brengt, het is och ook tussen particulieren onderling of tusschen dezen en kooplieden een alles behalve ongewoon verschijnsel.' De regering had nog aangevoerd dat de regeling vooral ook was voorgesteld met het oog op de 'boerenstand', hetgeen Van Maanen ontlokte: 'Die Haagse wettenmakers waren zeker geen buitenmenschen; want dan zouden zij zich wel gewacht hebben voor zulk een absurd beweren' (aangehaald door Aangehaald door J.G.J. Oetgens van Waveren Pancras Clifford, Eenige opmerkingen over den staat van kennelijk onvermogen (art. 882-885 Burg. Rechtsv.), Diss. Leiden, I887, p. 29).

38. De Vries, Het kennelijk onvermogen, p. 17. Uit ditzelfde wantrouwen jegens de particulier werd verklaard dat hij in meer gevallen blootstond aan lijfsdwang dan de failliete koopman (vgl. H.E. van Hees, Het kennelijk onvermogen in verband met het Ontwerp eener Wet op het Faillissement en de Surséance van betaling van de Staatscommissie van I879, Diss. Leiden, I89I, p. 63).

39. In de memorie van toelichting betoogde de regering: 'het zal wel geen betoog behoeven, dat de maatregelen en voorzorgen, die bij het faillissement van een koopman noodzakelijk zijn, om zijn boedel ten meesten voordeele zijner schuldeischers tot effenheid te brengen, evenzeer nuttig en doelmatig zijn bij het kennelijk onvermogen van iemand, die niet tot den handelsstand behoort, weshalve men daarin ook slechts die wijzigingen heeft gemaakt, welke noodwendig moeten voortvloeien uit den onderscheiden stand der beide personen'. Aangehaald door Oetgens van Waveren Pancras Clifford, Eenige opmerkingen over den staat van kennelijk onvermogen, p. 29. Deze schrijver vermeldt dat verzoeken om toepassing van de regeling (althans tot 1865 ) 'niet dikwijls' waren voorgekomen (p. 74).

40. Boedelafstand heeft Romeinsrechtelijke wortels en is wel beschouwd als vroegste in onze landen toegepaste regeling ten behoeve van crediteuren in tijden waarin overigens de strafrechtelijke benadering van insolventie nog voorop stond. Vgl. over de geschiedenis van het Nederlandse insolventierecht, Schuldsanering en goede trouw, p. I39 e.v. 


\subsection{De Faillissementswet}

De Faillissementswet van 1893 bracht een groot aantal verbeteringen. Het onderscheid tussen kooplieden en niet-kooplieden verviel, zij het niet zonder discussie over de vraag of voor particulieren het faillissement niet veel ernstiger gevolgen zou hebben dan bij een koopman. ${ }^{42}$ Een faillissement kan volgens art. I Fw worden uitgesproken, hetzij op eigen aangifte van de schuldenaar, hetzij op verzoek van één of meer schuldeisers of - om redenen van openbaar belang - op vordering (sinds 2002: verzoek) van het Openbaar Ministerie. Vereist is dat de schuldenaar verkeert in de toestand dat hij heeft opgehouden te betalen, hetgeen summierlijk dient te blijken (art. 6 lid 3 Fw).

Met het einde van het faillissement door het verbindend worden van de slotuitdelingslijst (art. I93 Fw) herkrijgt de schuldenaar de beschikking over zijn vermogen, hetgeen zowel voor hemzelf als voor zijn schuldeisers duidelijkheid schept. Het einde van het faillissement bevrijdt de schuldenaar echter niet van zijn resterende schulden. ${ }^{43}$ Nieuwe executiemaatregelen kunnen daarvoor worden genomen (doch slechts op de goederen, niet d.m.v. lijfsdwang: artikel I95 Fw). Ook een nieuw faillissement kan worden uitgesproken.

Tot de invoering van de schuldsaneringsregeling natuurlijke personen in 1998 is de Faillissementswet verschillende malen gewijzigd, doch meestal niet op wezenlijke punten. In I925 werden de mogelijkheden van surseance van betaling verruimd, waarna in 1935 aan de surseanceregeling de mogelijkheid van een dwangakkoord werd toegevoegd. 44 Verder kunnen genoemd worden: de wijzigingen uit I986 ter bestrijding van misbruik van rechtspersonen (verruiming faillissementspauliana en invoering bestuurdersaansprakelijkheid bij faillissement) en de invoering in 1992 van een afkoelingsperiode in faillissement en surseance. 45

4I. Bij de behandeling van de Faillissementswet in de Eerste Kamer werd opgemerkt dat van boedelafstand zo weinig gebruik werd gemaakt, dat het lijkt 'alsof er geen brave debiteuren zijn' (Van der Feltz I, p. 43).

42. Zo werd vanuit de Eerste Kamer aangevoerd: 'De gevolgen van het faillissement zijn voor den koopman geenszins altijd verwerpelijk. Schoon schip te maken is voor iemand, die daarna weder met nieuwen moed beginnen kan, soms een middel tot herstel van verloren krediet. Voor den nietkoopman daarentegen zijn die gevolgen vaak vernietigend.' (Van der Feltz I, p. 38).

43. Vanuit de Tweede Kamer was gewezen op de Engelse Bankruptcy Act I883, volgens welke de schuldenaar die te goeder trouw was de rechter om kwijtschelding kon vragen, maar volgens de regering voldeed die regeling niet en was zij daarom reeds in I89o gewijzigd (Van der Feltz II, p. 26I-262). De regering achtte kwijtschelding meer dan een een brug te ver (Van der Feltz II, p. 264-266): 'Kan men ook nog wenschen, dat de wet bepale, dat door zijne schulden de pen gehaald, of dat (...) die schulden verder geheel of nagenoeg onverhaalbaar zullen zijn? Op welken rechtsgrond een wetgever hiertoe zou mogen overgaan, ligt in 't duister.' Nee, het zou neerkomen op 'een premie op het faillietgaan' als de schuldenaar, die door de wet door het gerechtelijk akkoord reeds werd begunstigd, op grond van zijn faillissement boven andere schuldenaren zou worden bevoorrecht.

44. De regering sprak in de toelichting van een ontwikkeling van surseance tot een 'verzacht faillissement' (Van der Feltz III, p. 334).

45. Een kort overzicht is opgenomen in de toelichting bij het Voorontwerp-Insolventiewet, p. I3I-I32. 


\subsection{Naar een wettelijke schuldsaneringsregeling}

Hiervoor kwam al aan de orde dat in de loop van de twintigste eeuw grote welvaart is ontstaan, die gepaard is gegaan met - bevorderd is door - kredietverlening aan grote groepen consumenten. Geld lenen werd een doodnormaal verschijnsel, vaak zelfs fiscaal aftrekbaar. Krediet wordt door kredietverstrekkers nadrukkelijk, soms zelfs agressief, aan de man gebracht. Enige bescherming is beoogd met regulerende maatregelen, zoals de Wet op het consumentenkrediet (I990)..$^{6}$ Dat consumenten niettemin (te) gemakkelijk onverantwoorde risico's nemen, bleek wel toen grote groepen mensen zich bij stijgende aandelenkoersen en royale kredietmogelijkheden lieten verleiden tot aanschaf van een giftige combinatie: de 'winstverdriedubbelaar'. Met als bekend de Dexia-affaire tot gevolg. Kan men wellicht - achteraf - van deze mensen oordelen dat zij hun schuldproblemen mede aan eigen onvoorzichtigheid te wijten hadden, feit is ook dat de aanwezigheid van kredietmogelijkheden uiteindelijk bij vele mensen leidt tot problematische schuldsituaties. Dit vormt een maatschappelijk en dus ook politiek probleem dat, los van eventuele morele beoordelingen, om een pragmatische oplossing vraagt. 47

In de jaren negentig werd gepleit voor een oplossing naar Amerikaans voorbeeld: een regeling voor sanering van schulden van natuurlijke personen, waardoor het vooruitzicht van een faillissement met louter liquidatie van vermogen kon worden verruild voor een sanering van schulden, zodat daadwerkelijk een fresh start kon worden gemaakt. In de politiek werd de stoot gegeven tijdens de behandeling van een wetsvoorstel voor een algemene regeling voor beslag op loon en sociale uitkeringen, toen de Tweede Kamer bij motie de wens uitsprak dat 'het wenselijk is dat de schuldenlast van privé-personen, niet ondernemer zijnde, na verloop van tijd beëindigd wordt'. ${ }^{8}$

Het voorstel van wet tot wijziging van de Faillissementswet in verband met de sanering van schulden van natuurlijke personen (22 969) is eind 1992 bij de Tweede Kamer

46. Inmiddels is deze wet voor een belangrijk deel verwerkt in de Wet op het financieel toezicht. Sceptisch over de effectiviteit van de bescherming die deze wet de consument biedt tegen overcreditering: Noordam, Schuldsanering en goede trouw, p. 68.

47. De rechtspolitieke context is nader uiteengezet door Huls, Actie en reactie, p. 285.

48. Het ging om wetsvoorstel 17789 , houdende vaststelling van een algemene regeling van beslag op loon, sociale uitkeringen en andere periodieke uitkeringen. De motie was ingediend door het kamerlid Biesheuvel (Kamerstukken II I988/89, I7 789, nr. I9), mede naar aanleiding van een kritische beschouwing van Huls in het Nederlands Juristenblad (N.J.H. Huls, 'De Wet op het uitkeringsbeslag: levenslang voor iedereen? Een rechtspolitieke beschouwing', NJB I989, p. 52I-525). Opmerking verdient dat vanuit de Tweede Kamer al enige jaren eerder (nl. bij de behandeling van de regeling voor bestuurdersaansprakelijkheid bij faillissement) aandacht was gevraagd voor het probleem van het voortbestaan van schulden na beëindiging van het faillissement van natuurlijke personen. Bij de installatie van de Commissie Mijnssen in mei I986 bood de Minister van Justitie deze commissie uitdrukkelijk de ruimte om ook op dit punt voorstellen te doen (Rapport van de Commissie ter advisering omtrent de eventuele herziening van de Faillissementswet, Oktober I989, p. 285). Op het moment van aanvaarding van de motie Biesheuvel (29 april I989) zullen de voorstellen van de Commissie Mijnssen, die ten grondslag hebben gelegen aan de Wet schuldsanering natuurlijke personen, reeds grotendeels vaste vorm hebben gehad. Ik ga ervan uit dat Huls' beschouwing 'Van liquidatie naar rehabilitatie' uit november I988 - hoewel het niet is vermeld op de literatuurlijst in het rapport van de Commissie Mijnssen - van grotere invloed is geweest op de desbetreffende voorstellen. 
ingediend en pas op 25 juni 1998 wet geworden (Stb. 445). Omdat in de Eerste Kamer politieke problemen waren ontstaan in verband met de vrees ${ }^{49}$ dat de wet in de uitvoering te gecompliceerd zou uitpakken, is in 1997 een wijzigingsvoorstel ingediend (wetsvoorstel 25672 , ook bekend als: de novelle), dat op dezelfde dag als wetsvoorstel 22969 is afgedaan (Stb. 447)..$^{\circ}$ De genoemde wetten zijn op I december 1998 in werking getreden. ${ }^{5}$

\subsection{Eerste wijzigingen in de wettelijke schuldsaneringsregeling}

Een eerste evaluatie van de nieuwe regeling is in 200 I gepubliceerd..$^{2}$ Onverdeeld positief waren de bevindingen niet. De wetgever had drie doelstellingen geformuleerd:

- voorkomen dat natuurlijke personen tot in lengte van dagen door schuldeisers worden achtervolgd;

- bevorderen van de bereidheid van schuldeisers akkoord te gaan met een minnelijke regeling (de wettelijke regeling als 'stok achter de deur');

- terugdringen van het aantal faillissementen van natuurlijke personen.

Aan de eerste doelstelling werd volgens de onderzoekers voldaan. Daarbij werd echter wel aangetekend dat de integratie van de schuldsaneringsregeling met de schuldhulpverlening gebrekkig was, waardoor de duurzaamheid van de schone lei niet verzekerd is. Verder werd erop gewezen dat slechts een klein deel van de schuldenaren voor wie het minnelijke traject mislukt, vervolgens verzoeken om toepassing van de schuldsaneringsregeling. Verontrustend was ook dat er verschillende aanwijzingen waren dat de tweede doelstelling niet werd gehaald. Het lijkt erop, zo vatte de regering het samen, dat de Wsnp zelfs eerder als een 'stok naar de deur' dan als een 'stok achter de deur' werkt. 53 Het minnelijk traject kampte met dalende succescijfers. Schuldeisers bleken vaak een voorkeur te hebben voor het wettelijk traject boven het minnelijk traject, omdat dat strenger voor de schuldenaar is en vaak ook nog eens financieel gunstiger voor de schuldeisers. Dat de derde doelstelling, daling van het aantal faillissementen van natuurlijke personen, werd gehaald, is niet zo verrassend. Deze doelstelling lijkt mij echter slechts van beperkte betekenis, nl. in de mate dat de eerste doelstelling (restschuldbevrijding) wordt gerealiseerd.

49. De vrees was ingegeven, of in elk geval gevoed, door A. van Hees, 'De Eerste Kamer moet het wetsvoorstel Saneringsregeling natuurlijke personen verwerpen', NJB I996, p. 589-59I.

50. Stb. 446 van 1998 bevat de Invoeringswet schuldsaneringsregeling natuurlijke personen, dat de nodige aanpassingen aanbrengt in andere wetten dan de Faillissemenstwet. De parlementaire geschiedenis van de schuldsaneringsregeling is slechts ten dele uitgegeven (nl. in het in I995 verschenen derde deel van de Geschiedenis van de Faillissementswet onder redactie van Kortmann en Faber). Helaas ontbreken op www.overheid.nl/op de stukken van wetsvoorstel 22969 tot stuk nr. I6.

5I. Behalve deze wetten was er ter actualisering nog een veegwetje tot stand gebracht: de Tweede invoeringswet schuldsaneringsregeling natuurlijke personen (Stb. 1998, 448).

52. N. Jungmann, E. Niemeijer en M.J. ter Voert, Van schuld naar schone lei. Evaluatie Wet schuldsanering natuurlijke personen. WODC, $200 \mathrm{I}$.

53. Brief van 27 februari 2002 van de Ministers van Justitie en van Sociale Zaken en Werkgelegenheid (Kamerstukken II 200I-2002, 28 258, nr. I, p. 3). 
Niet lang daarna kwamen er verontrustender geluiden, ditmaal vooral vanuit de rechterlijke macht. Door stijgende aantallen verzoeken ontstond er een steeds grotere druk op de gerechten. Daarbij ervoeren rechters dat veel schuldsaneringszaken bewerkelijker waren dan verwacht, doordat veel schuldenaren niet goed bleken te beantwoorden aan het ideaalprofiel: de ongelukkige schuldenaar die door pech of een enkele misstap in de schuldproblemen is geraakt, maar nu o zo gemotiveerd is om de financiële bakens te verzetten. In werkelijkheid hadden veel schuldenaren behalve financiële nog vele andere problemen, waardoor zij in feite vaak 'niet klaar' waren voor het succesvol doorlopen van de regeling. De wet bood de rechter weinig mogelijkheid om schuldenaren in verband daarmee niet toe te laten tot de regeling en de Raad voor de rechtspraak vreesde dat zonder wetswijziging de insolventieafdelingen zouden vastlopen. ${ }^{54}$ De minister van Justitie nam de geluiden serieus en liet zich adviseren over wetswijzigingen die ertoe moesten leiden (I) dat de toelating tot de schuldsaneringsregeling substantieel werd beperkt door 'strenger op te treden bij de toegang' en (2) dat de regeling waar mogelijk werd vereenvoudigd. Het advies werd gevraagd van de Commissie insolventierecht, voor welk advies een breed samengestelde subcommissie (Commissie Schone Lei II $^{55}$ ) werd ingesteld met veel deskundigheid betreffende de schuldsaneringspraktijk. Eind 2004 kon een wetsvoorstel bij de Tweede Kamer worden ingediend, dat mede op basis van deze advisering was opgesteld. ${ }^{5} \mathrm{Na}$ een moeizame parlementaire behandeling, waarin het wetsvoorstel op enkele belangrijke onderdelen werd geamendeerd, is het wetsvoorstel uiteindelijk wet geworden en op r januari 2008 in werking getreden. ${ }^{57}$ Een nadere weergave van de afzonderlijke wijzigingen laat ik achterwege. Voorts ga ik hier nog niet in op de inhoud van de in november 2007 aangeboden voorstellen van de Commissie insolventierecht voor de vervanging van de Faillissementswet door een Insolventiewet, in welke voorstellen de schuldsanering voor natuurlijke personen duidelijk anders is vormgegeven dan thans.

54. In absolute aantallen leek er nog geen reden voor grote zorg: vooraf was gerekend op I5.00o toelatingen per jaar. Na nog geen 7000 toelatingen in 1999, steeg dat aantal in 2003 tot bijna II.000 zaken. Pas in 2006 en 2007 werd de grens van 15.000 (enigszins) overschreden. In 2008 tekent zich een scherpe daling af van het aantal toelatingen.

55. Deze naam verwijst naar de zogenoemde Commissie schone lei, die naar aanleiding van de in de Eerste Kamer gerezen problemen had geadviseerd over wijzigingen ter vereenvoudiging van de regeling en waarvan de resultaten zijn verwerkt in de 'novelle'.

56. Wetsvoorstel 29942 tot wijziging van de Faillissementswet n verband met de schuldsaneringsregeling natuurlijke personen. De Commissie insolventierecht meende dat met de in het wetsvoorstel voorgestelde maatregelen de door de minister geformuleerde doelen zouden kunnen worden bereikt, maar stelde daarbij wel nadrukkelijk de vraag wat er zou moeten gebeuren met de schuldenaren die door de strengere toelatingseisen niet voor schuldsanering in aanmerking zouden komen.

57. Gelet op de achtergrond van de wijzigingen is het opmerkelijk dat de wet dateert van 24 mei 2007 (Stb. I92) en de inwerkingtreding dus meer dan een half jaar later plaatsvond. Dit is geschied op nadrukkelijk verzoek vanuit de rechterlijke macht, om alle betrokkenen voldoende tijd te bieden om de invoering voor te bereiden. Des te vreemder is dit, als men bedenkt dat op de procedurele vereenvoudigingen in de praktijk al werd geanticipeerd (geen vaststelling van saneringsplannen, 'pro forma' verificatievergaderingen). 


\section{$4 \quad$ Het buitengerechtelijke ('minnelijke') traject}

Uit de doelstellingen van de schuldsaneringsregeling blijkt al het grote belang dat in Nederland wordt gehecht aan het minnelijke traject. Veel van de discussies over de wsnp hebben direct of indirect betrekking op het minnelijke traject en de wijze waarop dat versterkt kan worden. Jungmann, Niemeijer en Ter Voert beschouwen Nederland als een uitzondering op de ons omringende landen, in die zin dat Nederland reeds vóór de invoering van de schuldsaneringsregeling georganiseerde schuldhulpverlening kende, die wordt verleend door lokale organisaties voor schuldhulpverlening. ${ }^{8}$ Als dat juist is, zijn wellicht ook de problemen rond de verhouding tussen het minnelijke traject en het wettelijke traject specifiek voor Nederland. Daarbij doen zich soms lastige keuzes voor. De wetgever lijkt met de 'stok achter de deur'-filosofie bepaalde verschillen juist bewust te accentueren, ten einde de schuldeisers te stimuleren om in het minnelijke traject eieren voor hun geld te kiezen. Dethmers is echter van mening dat in een ideaal insolventierecht procedures buiten de insolventieprocedure en daarbinnen 'zo naadloos mogelijk' in elkaar dienen over te lopen; hij acht het zaak om boedelafdrachten, verificatiemethoden en uitdelingspercentages in beide stadia zoveel mogelijk aan elkaar gelijk te schakelen. ${ }^{59} \mathrm{Bij}$ deze benadering passen ook pleidooien om elementen uit het wettelijke traject, met name een moratorium voor (individuele) beslag- en executiemaatregelen, in het minnelijk traject toepasbaar te maken. Het verschil blijft natuurlijk wel dat in het wettelijke traject de schuldenaar niet meer (zelfstandig) kan beschikken over zijn vermogen, doordat daarop een gerechtelijk beslag ligt. Bij een moratorium buiten insolventie kunnen de belangen van schuldeisers dus gemakkelijk in de knel komen.

\section{I Enige gegevens over minnelijke schuldhulpverlening}

Voor goed begrip zijn enige gegevens over de minnelijke schuldhulpverlening in Nederland nuttig. ${ }^{60}$ Organisaties die zich reeds langere tijd met minnelijke schuldhulpverlening bezighouden zijn gemeentelijke kredietbanken, sociale diensten en het maatschappelijk werk. Kredietbanken zijn al ruim voor de Tweede Wereldoorlog ontstaan om door sociale kredietverlening woeker tegen te gaan, maar zijn zich allengs meer op schuldhulpverlening gaan toeleggen toen de commerciële kredietverlening aan consumenten na de oorlog een grote vlucht nam. Hun koepelorganisatie, de Nederlandse Vereniging van Volkskrediet (NVVK) heeft in 1979 de Gedragscode Schuldregeling opgesteld, die - na wijzigingen - nog steeds een belangrijke rol vervult

58. Jungmann, Niemeijer en Ter Voert, Van schuld naar schone lei, p. 25. Of Nederland hierin inderdaad een uitzondering vormt, weet ik niet. In elk geval schijnt er in de Verenigde Staten een aanzienlijke praktijk te bestaan van lokale buitengerechtelijke schuldhulpverlening. Zie T.A. Sullivan, E. Warren en J.L. Westbrook, 'Who uses Chapter I3?' in: J. Niemi-Kiesiläinen, I. Ramsay en W. Whitford (eds.), Consumer Bankruptcy in Global Perspective, p. 269-282, aldaar p. 270, noot 3.

59. H.H. Dethmers, 'De schuldsaneringsregeling processueel benaderd', Tijdschrift voor Civiele Rechtspleging 2007, p. 90-I00, aldaar p. 90.

6o. De gegevens zijn vooral ontleend aan de beschrijving van de minnelijke schuldhulpverlening door Jungmann, De Wsnp: bedoelde en onbedoelde effecten op het minnelijk traject, p. 2I-30. Zie ook Noordam, Schuldsanering en goede trouw, p. 69-82. 
in de schuldhulpverlening. Ook voor gemeentelijke sociale diensten, verantwoordelijk voor de verstrekking van bijstandsuitkeringen aan mensen zonder ander inkomen, heeft schuldhulpverlening zich pas in de jaren tachtig ontwikkeld tot een reguliere taak. Het belang daarvan hing samen met het feit dat mensen die in verband met schuldproblemen uit hun woning werden gezet, vaak bij sociale diensten voor hulp terechtkwamen. Verder bleek dat voor cliënten van sociale diensten schulden een wezenlijke belemmering vormden om betaald werk te aanvaarden, omdat indertijd op salaris verdergaand beslag kon worden gelegd dan op een uitkering.

Hoewel sinds de jaren negentig onderkend wordt dat behalve het oplossen van problematische schuldsituaties ook het aanpakken van de achterliggende psychosociale problemen aandacht verdient ('integrale schuldhulpverlening'), is er nog steeds geen sprake van een uniforme uitvoeringspraktijk. Lokale verschillen hangen mede samen met de omstandigheid dat schuldhulpverlening wordt gerekend tot de beleidsvrijheid van gemeenten. ${ }^{61}$ Deze omstandigheid heeft de centrale overheid (het ministerie van Sociale Zaken en Werkgelegenheid) er lange tijd van weerhouden een krachtiger beleid te voeren om de minnelijke schuldhulpverlening te ondersteunen. Inmiddels is daarin onder druk van de Tweede Kamer verandering gekomen. In april 2006 heeft de Tweede Kamer de regering verzocht de minnelijke schuldhulpverlening 'te bewerktuigen en wettelijk in te bedden zodat het resultaat daarvan is dat de minnelijke regeling ten minste driekwart van de schuldsanering realiseert' ${ }^{62}$

Welke hulp kunnen schuldenaren in het kader van de minnelijke schuldhulpverlening nu eigenlijk ontvangen? De eigenlijke schuldhulp bestaat in het voorstellen en - bij aanvaarding - uitvoeren door de schuldhulpverlener van een 'minnelijke schuldregeling', vastgelegd in een schriftelijke schuldregelingsovereenkomst tussen de schuldenaar en zijn schuldeisers, waardoor de problematische schuldsituatie kan worden opgelost. Onderdeel van een minnelijke schuldregeling kan zijn dat de schuldeisers met behulp van een saneringskrediet direct de afgesproken bedragen ontvangen. Is dat niet het geval, dat zal de schuldenaar gedurende de looptijd maandelijks aan de schuldeisers aflossen. In het laatste geval kunnen de bedragen worden aangepast als gedurende de looptijd van de regeling wijziging optreedt in de inkomsten van de schuldenaar. Naast deze hulp in de vorm van schuldregelingen worden aan schuldenaren diverse vormen van budgethulp geboden, variërend van budgetadvies of financieel beheer (waarbij het inkomen rechtstreeks wordt overgemaakt naar

6r. De meeste gemeenten voeren de activiteiten in het kader van de schuldhulpverlening uit vanuit hun zorg om het welzijn van de burgers dan wel in het kader van hun armoedebeleid. Er bestaat op dit punt geen wettelijke grondslag of opdracht. In de sfeer van de bijstandverlening bevatten de artikelen $\mathrm{I}_{3}, 48$ en 49 van de Wet werk en bijstand enige regels over bijstandsverlening in verband met een schuldenlast.

62. Motie van Noorman-Den Uyl c.s., Kamerstukken II 2006-2007, 24 515, nr. 74. Naar aanleiding van de motie heeft de regering aangekondigd te gaan onderzoeken of een wettelijke basis voor minnelijke schuldhulpverlening bijdraagt aan het versterken ervan en of de minnelijke schuldhulpverlening erbij gebaat zou zijn als gemeenten meer bevoegdheden krijgen, bijvoorbeeld op het terrein van verplicht budgetbeheer; de regering overweegt daarbij ook een wettelijke aanspraak op schuldhulpverlening te formuleren (brief van I9 oktober 2007 aan de Tweede Kamer, Kamerstukken II 2007-2008, 24 5I5, nr. II9, p. 2). De bevindingen van het onderzoek zullen waarschijnlijk in september 2008 worden bekendgemaakt. Naar ik heb begrepen is in het onderzoek bijvoorbeeld ook gekeken naar maatregelen in de sfeer van beschermingsbewind en curatele. 
de schuldhulpverlener, die dit na inhouding van de aflossing doorbetaalt aan de schuldenaar) tot budgetbeheer (waarbij ook de betaling van de vaste lasten door de hulpverlener plaatsvindt). In aanvulling daarop wordt vaak psychosociale hulp geboden, om een gedragsverandering bij de schuldenaar te bevorderen en zo de kans op nieuwe schuldproblemen te verkleinen. Onder omstandigheden kunnen schuldenaren ook in aanmerking komen voor financiële ondersteuning van gemeentewege, bijvoorbeeld in de vorm van een garantstelling ten behoeve van een saneringskrediet.

Vanaf begin 2008 is de NVVK bezig met het doorvoeren van wijzigingen in de schuldhulpverlening. Aanleiding daarvoor zijn de teleurstellende slagingspercentages van het minnelijke traject (in 1992 was het nog 53\%, doch daarna trad een gestage daling in tot slechts $9 \%$ in 2004), ${ }^{63}$ en daarnaast de vele afwijzingen van aanvragen voor een schuldregeling. Behalve het 'centraal stellen van de vraag van de schuldenaar' en het 'meer met elkaar in verband brengen' van de verschillende vormen van dienstverlening, is een 'stabilisatietraject' geïntroduceerd, waarbij financiële rust bij de schuldenaar wordt gecreëerd door intensief budgetbeheer. ${ }^{64}$

\subsection{Wettelijke beperkingen voor schuldbemiddeling}

Hiervoor kwam aan de orde dat de schuldhulpverlening met name wordt verleend door gemeentelijke kredietbanken, sociale diensten en het maatschappelijk werk. Aan de kring van schuldhulpverleners zijn grenzen gesteld in de Wet op het consumentenkrediet. Professionele dienstverlening, gericht op het totstandkomen van een regeling met betrekking tot de schuldenlast van natuurlijke personen, is namelijk verboden, tenzij wordt voldaan aan artikel 48 van die wet. ${ }^{65}$ Artikel 48 staat schuldbemiddeling toe aan gemeenten, gemeentelijke kredietbanken en gemeentelijke instellingen, die zich krachtens hun doelstelling met schuldbemiddeling bezighouden, en voorts aan advocaten, notarissen, deurwaarders, accountants en curatoren/bewindvoerders die zijn aangesteld op grond van de Failissementswet. Daarnaast is professionele schuldbemiddeling toegestaan als zij plaatsvindt om niet, waarbij gedacht kan worden aan bemiddelaars die beloond worden met provisie van de schuldeisers of die nadien beloond worden voor aansluitend verleend budget-

63. Jungmann, De Wsnp, bedoelde en onbedoelde effecten op het minnelijke traject, p. 8. Het jaarverslag 2007 van de NVVK vermeldt voor 2006 een slagingspercentage van I $\%$ en voor 2007 van $22 \%$. Er is derhalve duidelijk sprake van een gunstige ontwikkeling.

64. Op de website van de NVVK (www.nvvk.eu) valt hierover te lezen: 'Deze intensieve vorm van budgetbeheer mikt op financiële stabiliteit. De primaire levensbehoeften van de klanten worden samen met de gemeente zeker gesteld. Dat gebeurt op basis van een analyse van de financiën die helpt inkomsten en uitgaven op elkaar af te stemmen. Deze aanpak betekent ook dat schuldeisers in een vroeg stadium bij het probleem worden betrokken.'

65. Het verbod wordt in artikel 47 geformuleerd als een verbod op 'schuldbemiddeling': het in de uitoefening van een bedrijf of beroep, anders dan door het aangaan van een krediettransactie, verrichten van diensten, gericht op de totstandkoming van een regeling met betrekking tot de bestaande schuldenlast van een natuurlijke persoon, geheel of gedeeltelijk voortvloeiend uit een of meer krediettransacties. 
beheer. ${ }^{66}$ En ten slotte mag professionele schuldbemiddeling plaatsvinden door bij algemene maatregel van bestuur aan te wijzen (categorieën van) personen. Een zodanige algemene maatregel van bestuur is slechts in de jaren I998-2000 van kracht geweest. Een element dat hier nog kort vermelding verdient is dat er de afgelopen jaren gestreefd wordt te komen tot certificering van schuldhulpverleningsorganisaties, zodat aan schuldenaren en schuldeisers een bepaald kwaliteitsniveau kan worden gewaarborgd. Artikel 48 van de Wet op het consumentenkrediet biedt sinds de wijzigingen in de schuldsaneringsregeling van I januari 2008 de mogelijkheid om aan schuldbemiddelaars bij algemene maatregel van bestuur de voorwaarde te stellen dat zij beschikken over een certificaat. Deze bepaling beoogt te stimuleren dat 'het veld' komt tot een vorm van vrijwillige certificering en past dus in de tendens om het minnelijk traject door (al dan niet vrijwillige) regulering verdergaand te professionaliseren. Naar verwachting zal certificering pas in 2009 daadwerkelijk van de grond komen.

Een consequentie van de beperkingen van de Wet op het consumentenkrediet is dat professionele wnsp-bewindvoerders, als zij niet ook behoren tot de in artikel 48 bedoelde categorieën, ${ }^{67}$ niet kunnen optreden als schuldhulpverlener in het minnelijke traject. Dit vormt een verschil met de Belgische regeling, volgens welke één schuldbemiddelaar zowel de minnelijke als de gerechtelijke aanzuiveringsregeling voor zijn rekening neemt. De Commissie insolventierecht is bij het schrijven van het Voorontwerp-Insolventiewet ervan uitgegaan dat het minnelijk en het wettelijke traject door één - aanvankelijk stille - bewindvoerder moet kunnen worden uitgevoerd.

\subsection{Medewerking van schuldeisers}

Uit de in 200I gepubliceerde evaluatie van de schuldsaneringsregeling bleek dat schuldeisers in veel gevallen een voorkeur hebben voor het wettelijke traject. ${ }^{68}$ Tot de 'dwarsliggers' behoren vaak ook overheidsinstanties als het Centraal Justitieel Incassobureau (CJIB) en instellingen die op grond van sociale verzekeringswetgeving onterecht uitgekeerde bedragen terugvorderen. Het gaat dus uitgerekend om instellingen die behoren tot de beleidsverantwoordelijkheid van de ministers van Justitie en van Sociale Zaken en Werkgelegenheid, die eveneens verantwoordelijk zijn voor

66. Aldus de minister van Justitie in een brief van 27 oktober 2006 (Kamerstukken II 2006-2007, 29 942 , nr. 33, p. 4). Op hulp bij het regelen van schulden die plaatsvindt buiten beroep of bedrijf, zoals door vrienden of familie van de schuldenaar, of door kerkelijke instelingen, is de Wet op het consumentenkrediet niet van toepassing en houdt zij dus generlei beperking in. Nogal ongelukkig is echter dat de wettelijke schuldsaneringsregeling slechts van toepassing kan worden verklaard als gepoogd is te komen tot een buitengerechtelijke schuldregeling door een persoon of instelling als bedoeld in artikel 48, eerste lid, van de Wet op het consumentenkrediet (artikel 288, tweede lid, onder b, Rv). Vgl. Rechtbank Rotterdam 4 februari 2008, Schuldsanering 2008/4, nr. 252, in welke zaak het verzoek van de schuldenaar op deze grond werd afgewezen.

67. Artikel 48 Wck noemt weliswaar bewindvoerders, maar door de eis dat zij benoemd moeten zijn op grond van de Faillissementswet kunnen bewindvoerders niet reeds in het minnelijke traject voor een schuldenaar optreden.

68. Die perceptie leefde ook bij de gerechten. Zie N.J.H. Huls en V. Schellekens, 'Je ziet de gaten in hun handen', De eerste ervaringen vna rechtbanken en gerechtshoven met de toepassing van de Wet schuldsaneringsregeling natuurlijke personen, Utrecht, 200I, p. 43-45. 
de schuldsaneringsregeling en de minnelijke schuldhulpverlening! Voor de sociale zekerheidsinstellingen (SVB en UWV) wordt thans een wettelijke regeling voorbereid, die ertoe strekt dat deze instellingen hun medewerking kunnen gaan verlenen aan minnelijke regelingen. ${ }^{6}$ Voor de positie van het CJIB is van belang dat het gaat om door de strafrechter opgelegde sancties, ten aanzien waarvan de wettelijke plicht bestaat tot tenuitvoerlegging 'zodra mogelijk' (art. 56I lid I Wetboek van Strafvordering). In het kader van de wijzigingen in de schuldsaneringsregeling van I januari 2008 is de positie van het CJIB gewijzigd om medewerking aan minnelijke schuldregelingen mogelijk te maken. Daartoe is in 56r Sv de mogelijkheid om uitstel van betaling te verlenen verlengd met de duur van een minnelijke schuldregeling. Tevens is in artikel 76 a Wetboek van Strafrecht bepaald dat de verjaringstermijn van het recht tot uitvoering van straffen niet loopt gedurende de toepassing van de (wettelijke) schuldsaneringsregeling. Hierdoor kan de incasso van strafrechtelijke vorderingen in geval van medewerking aan een minnelijke regeling niet gefrustreerd worden doordat de schuldenaar 'de wnsp induikt' (zij vallen in dat geval ook niet onder de schone lei: art. 358 lid 4 Fw). Bij dit alles is niet getornd aan de wettelijke verplichting tot tenuitvoerlegging voor het volledige bedrag. ${ }^{70}$

\subsection{Gedwongen medewerking van schuldeisers}

Wezenlijk kenmerk van minnelijke schuldregelingen is dat het gaat om een overeenkomst tussen de schuldenaar en zijn schuldeisers, dan wel een samenhangende reeks van overeenkomsten van de schuldenaar met zijn schuldeisers. Het aangaan van een overeenkomst geschiedt op basis van vrijwilligheid. Voor een alomvattende minnelijke regeling is dus de instemming nodig van alle schuldeisers. Elke schuldeiser heeft de vrijheid om zijn instemming te weigeren, bijvoorbeeld in de hoop op een gunstiger aanbieding of de verwachting dat bij een gerechtelijke insolventieprocedure een hoger bedrag kan worden gerealiseerd. Ook niet-financiële motieven kunnen een rol spelen, bijvoorbeeld de behoefte om de schuldenaar te 'straffen' voor zijn wanbetaling.

In de jurisprudentie wordt onder omstandigheden geoordeeld dat het een schuldeiser niet vrijstaat zijn instemming met een schuldregeling te weigeren. Dat zal met name het geval zijn als de schuldeiser misbruik maakt van zijn bevoegdheid om een hem gedaan aanbod af te wijzen. Artikel 3:I3 lid I BW luidt immers: 'Degene aan wie een bevoegdheid toekomt, kan haar niet inroepen, voor zover hij haar misbruikt.' Van misbruik kan volgens lid 2 van hetzelfde artikel onder meer sprake zijn in geval men,

69. Voorstel van wet tot wijziging van enkele socialezekerheidswetten teneinde de Sociale verzekeringsbank en het Uitvoeringsinstituut werknemersverzekeringen de mogelijkheid te geven om van terugvordering af te zien door medewerking aan voorstellen tot schuldregeling, waarover de Raad van State in juni 2008 advies heeft uitgebracht.

70. Voor de toelichting zie men Kamerstukken II 2006-2007, 29 942, nr. 24, p. 4-5. Er is ook kritiek geuit op het uitgangspunt van onverkorte inning van strafrechtelijke vorderingen, o.m. door de Commissie insolventierecht en haar subcommissie Schone Lei II en nadien door S.C.J.J. Kortmann, 'Vergroot de kans van slagen van het minnelijk traject', Tijdschrift voor Insolventierecht 2007, p. 38-39. In België heeft de wetgever zich - evenmin onomstreden - op een vergelijkbaar standpunt als de Nederlandse wetgever gesteld, zo begrijp ik uit K. Broeckx, B. de Groote en S. Voet, 'Grondige revisie van de collectieve schuldregeling', Tijdschrift voor privaatrecht 2007, p. I547-I637, aldaar p. 1562 (noot 27). 
in aanmerking nemende de onevenredigheid tussen het belang bij de uitoefening en het belang dat daardoor wordt geschaad, naar redelijkheid niet tot die uitoefening had kunnen komen. Op deze grondslag kan in kort geding tegen weigerachtige schuldeisers worden opgekomen. ${ }^{7 \mathrm{I}}$ In een vonnis van de President van de rechtbank Zwolle van 2 februari 200I (Kort Geding 200I, I36) wordt de (lagere) jurisprudentie aldus samengevat dat dwangdeelname aan een onderhands akkoord alleen zal kunnen worden toegewezen indien een saneringsvoorstel wordt aangeboden:

- dat door een onafhankelijke deskundige is getoetst;

- dat goed gedocumenteerd en financieel transparant is;

- dat duidelijk maakt dat de schuldenaar zich een uiterste krachtsinspanning heeft getroost;

- en dat duidelijk maakt dat het alternatief (faillissement of wettelijke schuldsanering) bepaald geen uitzicht biedt.

Als belangen aan de zijde van de schuldeiser kunnen volgens hetzelfde Zwolse vonnis onder meer worden meegewogen:

- $\quad$ een financieel belang bij gewone (volledige) nakoming;

- gedwongen deelname aan een onderhands akkoord werkt concurrentieverstorend;

- $\quad$ gedwongen deelname heeft precedentwerking voor andere gevallen waarin een schuldenaar in vergelijkbare omstandigheden verkeert.

De Hoge Raad heeft evenwel in een arrest van I2 augustus 2005, NJ 2006, 230, m.nt. P. van Schilfgaarde (Payroll) onderstreept dat hier voor de rechter 'terughoudendheid' geboden is en 'slechts onder zeer bijzondere omstandigheden' plaats kan zijn voor een bevel aan een schuldeiser om zijn medewerking te verlenen aan een hem aangeboden buitengerechtelijk akkoord. Het betrof een zaak waarin de betrokken schuldeiser (Payroll) eerst het faillissement van de schuldenaar had verzocht, hoewel zij ter zitting verklaarde zich te realiseren 'dat zij bij een faillissement niets ontvangt'. Het Hof oordeelde dat Payroll haar bevoegdheid tot het aanvragen van het failissement had misbruikt en vernietigde het faillissement. ${ }^{72}$ De door de schuldenaar tegen Payroll ingestelde rechtsvordering tot medewerking aan een minnelijke schuldregeling werd echter in drie instanties afgewezen. Ik citeer de kernoverwegingen van de Hoge Raad:

'3.5.3 (...) De omstandigheid dat een schuldeiser de slechte financiële positie van de schuldenaar of diens dreigende faillissement kent of behoort te kennen, zal in het algemeen niet voldoende zijn om de gevolgtrekking te wettigen dat die schuldeiser misbruik maakt van zijn bevoegdheid te weigeren met het hem aangeboden buitengerech-

7I. Hoge Raad 2I mei I999, NJ I999, 507, in welk arrest de Hoge Raad voorts overweegt dat van misbruik pas sprake kan zijn als de schuldeiser de bedoelde onevenredigheid tussen de wederzijdse belangen kent dan wel behoort te kennen. Zie voorts Hof Leeuwarden Io september 1997, NJ I998, 930 en - voor inhoudelijke criteria - Rechtbank Zwolle 2 februari 200I, KG 200I, 136.

72. Zie de conclusie van A-G Spier voor het arrest van de Hoge Raad van 6 februari 2004, LJN Aor340, waarbij het cassatieberoep op grond van art. 8I RO werd verworpen. 
telijk akkoord in te stemmen. Tegenover het belang van de schuldeiser bij voldoening van zijn vordering door verhaal op alle goederen van zijn schuldenaar, zal het belang van de schuldenaar dat door de instemming van de in het geding betrokken schuldeiser met het akkoord de mogelijkheid bestaat dat een faillissement, surséance van betaling of schuldsaneringsregeling wordt voorkomen doorgaans niet zwaar genoeg wegen, terwijl in beginsel van de individuele schuldeiser niet behoeft te worden gevergd dat deze het belang laat prevaleren dat de schuldenaar beoogt te behartigen, namelijk dat hij (sneller) van zijn bestaande schuldenlast wordt bevrijd indien alle schuldeisers met het buitengerechtelijk akkoord instemmen. Daarbij moet worden bedacht dat tot de belangen die aan de zijde van de schuldeiser een rol kunnen spelen behoort dat bij een buitengerechtelijk akkoord de waarborgen ontbreken die de Faillissementswet biedt met betrekking tot de vaststelling van en het toezicht op de vermogenspositie van de schuldenaar door de curator of de bewindvoerder en de rechter-commissaris.

3.5.4 Uit het voorgaande volgt dat bij de toewijzing van een vordering tot medewerking aan een buitengerechtelijk akkoord terughoudendheid geboden is en dat slechts onder zeer bijzondere omstandigheden plaats kan zijn voor een bevel aan een schuldeiser om aan de uitvoering van een hem aangeboden akkoord mee te werken. Het ligt in beginsel op de weg van de schuldenaar die zodanige medewerking in rechte wenst af te dwingen de specifieke feiten en omstandigheden te stellen en, zo nodig, te bewijzen, waaruit kan worden afgeleid dat de schuldeiser naar redelijkheid niet tot weigering van instemming met het akkoord heeft kunnen komen.'

Ten tijde van het arrest van de Hoge Raad was wetsvoorstel 29 942, dat uiteindelijk op I januari 2008 in werking zou treden, reeds ingediend. Onderdeel van het wetsvoorstel was een nieuw artikel $287 \mathrm{a} \mathrm{Fw}$, dat de rechter die oordeelt over een verzoek tot toepassing van de schuldsaneringsregeling tevens bevoegd maakt te oordelen over een gelijktijdig gedaan verzoek om een schuldeiser te bevelen mee te werken aan een minnelijke schuldregeling. Als grondslag voor de beoordeling zou ook de insolventierechter art. 3:13 BW moeten hanteren. Door de combinatie met het wsnpverzoek zou de rechter, zo was de verwachting, beter geïnformeerd zijn over de omstandigheden van het geval en zouden onnodige toelatingen tot de wettelijke schuldsaneringsregeling kunnen worden vermeden. Vanuit de schuldhulpverleningspraktijk werd veel verwacht van dit 'dwangakkoord'. Het arrest van de Hoge Raad temperde deze verwachtingen aanzienlijk. Dethmers meent zelfs dat de wetgever er beter aan had gedaan de rechter een zelfstandige bevoegdheid tot vaststelling van een schuldregeling te verlenen. ${ }^{73}$

73. Dethmers, 'De schuldsaneringsregeling processueel benaderd', p. 98. Voor een zodanige inbreuk op de autonomie van schuldeisers zie ik onvoldoende grond. Het zou ook de vraag oproepen waarom in het kader van de wettelijke insolventieprocedures over een akkoord nog gestemd zou moeten worden. In het Voorontwerp-Insolventiewet is voorgesteld om ook buiten insolventie stemming over een akkoord mogelijk te maken. A.M.J. van Buchem-Spapens en Th.A. Pouw, Faillissement, surseance van betaling en schuldsanering, Monografieën privaatrecht 2, achtste druk, 2008, p. 130, wijzen erop dat de wetgever in het arrest geen aanleiding heeft gezien het toen al voorgestelde art. 287a aan te scherpen. Op zichzelf was dat natuurlijk denkbaar geweest, maar gelet op de toch al moeizame behandeling van wetsvoorstel 29942 en het feit dat de Commissie insolventierecht te kennen had gegeven met een verdere uitwerking te zullen komen, is daarvoor niet gekozen. 
Intussen kan met de Hoge Raad worden ingestemd, dat bij de beoordeling van een vordering tot medewerking aan een minnelijke schuldregeling gewicht toekomt aan het feit dat in een insolventieprocedure waarborgen bestaan voor de vaststelling van de vermogenspositie van de schuldenaar en het toezicht daarop. Ook in de lagere jurisprudentie werd daarom reeds geëist dat het voorstel van de schuldenaar ten minste moet zijn getoetst door een onafhankelijke deskundige, goed gedocumenteerd is en financieel transparant. Voorts onderschrijf ik dat de individuele schuldeiser in beginsel zijn eigen belang niet ten achter hoeft te stellen bij het belang van de schuldenaar om met alle schuldeisers tot overeenstemming te kunnen komen en zo (sneller) van zijn schuldenlast bevrijd te raken. Wel vind ik dat naarmate meer schuldeisers reeds hebben ingestemd, aan de positie van de overige schuldeisers minder gewicht kan toekomen. Waar een gekwalificeerde meerderheid van de schuldeisers bij een aanbod van een gerechtelijk akkoord de minderheid in beginsel (want behoudens weigering van homologatie) kan binden, mag van mij ook in het minnelijk traject rekening worden gehouden met de getalsverhoudingen van instemmende en niet-instemmende schuldeisers.

Een zekere aarzeling heb ik bij de gedachte dat het belang van een schuldeiser bij voldoening van zijn vordering door verhaal op alle goederen 'doorgaans' zwaarder weegt dan het belang van de schuldenaar dat door instemming van deze schuldeiser de mogelijkheid bestaat dat een insolventieprocedure wordt voorkomen. Van belang lijkt mij dat het verhaalsbelang in veel gevallen (misschien zelfs: doorgaans) uiterst beperkt is. Vaak overtreffen de boedelschulden de baten van de boedel en als er al iets kan worden uitgekeerd, ontvangen de schuldeisers - en zeker de concurrente schuldeisers - slechts een gering percentage. Bij een akkoord, minnelijk of gerechtelijk, wordt nog wel eens bijgedragen door derden, waardoor het resultaat gunstiger is dan bij liquidatie van het vermogen. Door dit alles vraag ik mij af of het verhaalsbelang niet enigszins gerelativeerd zou mogen worden, bijvoorbeeld tegen de achtergrond van art. 332 lid 4 Fw. ${ }^{74}$

Dat de stelplicht en de bewijslast van de relevante omstandigheden bij de schuldenaar liggen, lijkt mij juist. Dat het daarbij, zoals de Hoge Raad overweegt, zal moeten gaan om 'zeer bijzondere omstandigheden', komt mij te streng voor. Naar mijn mening zou bij de beoordeling van de weigering van de schuldeiser wat meer gelet mogen worden op de maatschappelijke wenselijkheid - zoals door regering en parlement bestendig benadrukt - van een zo effectief mogelijk minnelijk traject en van het vermijden van insolventieprocedures.

Tot slot van deze paragraaf vermeld ik een mogelijke positieve tendens. In de derde editie van de 'Monitor Wsnp' wordt verslag gedaan van onderzoek naar het beleid van schuldeisers. Dit levert indicaties op dat schuldeisers nu, in vergelijking met de evaluatie van 200I, positiever staan tegenover de minnelijke regeling. ${ }^{75}$

74. Art. 332 lid 4 Fw geeft de rechter-commissaris bij een aanbod van een gerechtelijk akkoord onder omstandigheden de mogelijkheid de tegenstemmen van schuldeisers buiten beschouwing te laten, indien deze schuldeisers in redelijkheid niet tot dit stemgedrag hebben kunnen komen. Daarbij moeten alle omstandigheden in aanmerking worden genomen, doch 'in het bijzonder' het percentage dat die schuldeisers, zou de toepassing van de schuldsaneringsregeling worden voortgezet, naar verwachting aan betaling op hun vorderingen zullen ontvangen. 


\section{De procedure}

In deze paragraaf zal ik de hoofdlijnen van de schuldsaneringsregeling natuurlijke personen schetsen. De regeling is te vinden in titel III van de Faillissementswet (titel I betreft faillissement en titel II surseance van betaling). Een groot aantal bepalingen van de faillissementsregeling is van (overeenkomstige) toepassing verklaard. ${ }^{76}$

\section{I Het verzoek}

De schuldsaneringsregeling kan slechts worden toegepast op verzoek van de schuldenaar zelf (art. 284 lid I Fw). ${ }^{77}$ Heeft een schuldeiser (of de schuldenaar zelf) eerst een faillissementsverzoek gedaan, dan wordt de schuldenaar in de gelegenheid gesteld zijnerzijds een schuldsaneringsverzoek te doen (art. 3 Fw); een ingediend schuldsaneringsverzoek heeft, ook indien later ingediend, prioriteit (art. 3a Fw). ${ }^{78}$ De schuldenaar heeft voor het wsnp-verzoek de medewerking nodig van zijn echtgenoot of geregistreerde partner, tenzij iedere gemeenschap van goederen is uitgesloten. In of bij het verzoek dient een gedetailleerde opgave te worden gedaan van relevante gegevens (art. 285 lid I Fw). In het bijzonder is nodig een verklaring 'dat er geen reële mogelijkheden zijn om tot een buitengerechtelijke schuldregeling te komen, alsmede over welke aflossingsmogelijkheden de verzoeker beschikt'. Deze '285-verklaring' vormt een scharnier tussen het minnelijke en het wettelijke traject. De schuldenaar kan de verklaring verkrijgen van burgemeester en wethouders van zijn gemeente, of van een gemeentelijke kredietbank. ${ }^{79}$ Ontbreken er gegevens, dan kan de rechter de schuldenaar een maand respijt bieden; ontbreken de gegevens dan nog, dan wordt hij niet-ontvankelijk verklaard. ${ }^{80}$

75. Marijke von Bergh e.a, Monitor Wsnp, derde meting, november 2007, p. 45. De Monitor Wsnp verschijnt jaarlijks en bevat gedetailleerde onderzoeksgegevens over de effectiviteit van de schuldsaneringsregeling.

76. Met de wijzigingen van 2008 is ernaar gestreefd regels die een equivalent bij faillissement kennen, niet langer uit te schrijven maar te vervangen door een verwijzing - een techniek die de consistentie ten goede komt maar niet altijd ook de leesbaarheid.

77. Met het oog op noodgevallen is ook voorzien in een wsnp-verzoek door burgemeester en wethouders van de woon- of verblijfplaats van de schuldenaar (art. 284 lid 3 Fw), maar die mogelijkheid wordt niet of nauwelijks toegepast.

78. De regels voor samenloop zijn nogal ingewikkeld en geven de rechtbanken volgens Dethmers 'een hoop rompslomp' (Dethmers, Van schuldsanering tot schone lei, p. 2I). Hoewel de schuldenaar volgens art. 3 Fw door de griffier gedurende veertien dagen in de gelegenheid wordt gesteld een wsnp-verzoek te doen, moet ook een na die termijn ingediend verzoek leiden tot schorsing van het faillissementsverzoek (HR 6 april 2007, JOL 2007, 235, TvI 2007, p. I43). Is een tijdig wsnp-verzoek uitgebleven door niet aan de schuldenaar toerekenbare omstandigheden, dan kan een uitgesproken faillissement alsnog worden omgezet in toepassing van de schuldsaneringsregeling (art. I5 b Fw).

79. De wet verwijst ook naar artikel 48, eerste lid onder d, Wck, maar omdat een algemene maatregel van bestuur als in die bepaling bedoeld, niet van kracht is, heeft deze verwijzing thans geen betekenis.

8o. Art. 287 lid 2 Fw. Dit is ook het geval als de 285 -verklaring ontbreekt. Als de schuldenaar nadien wel over de gegevens beschikt, kan hij een nieuw verzoek doen. 
Opmerkelijk genoeg houdt de wet niets in over een mondelinge behandeling van het verzoek. Dethmers vermeldt dat schuldeisers niet maar de verzoeker doorgaans wel wordt gehoord, eventueel door een gerechtssecretaris, achter gesloten deuren. ${ }^{8 \mathrm{I}}$ Zowel toewijzing van het verzoek als afwijzing geschiedt in een vonnis. ${ }^{82}$ Artikel 6 EVRM brengt mee dat ook afwijzingen in het openbaar moeten worden uitgesproken. ${ }^{8}$

Tegelijk met het wsnp-verzoek kunnen twee verzoeken worden gedaan die bij toewijzing inwilliging van het wsnp-verzoek (op dat moment) overbodig maken. In de eerste plaats een verzoek om bepaalde voorlopige voorzieningen (wel aangeduid als een 'moratorium') met het oog op het alsnog doen slagen van een minnelijke schuldregeling (art. 287b Fw). De voorzieningen gelden voor maximaal zes maanden; het wsnp-verzoek wordt zolang aangehouden. ${ }^{84}$ In de tweede plaats een verzoek om één of meer schuldeisers te bevelen om alsnog in te stemmen met een eerder afgewezen minnelijke schuldregeling (art. 287a Fw). Processueel zijn deze verzoeken wat vreemde eenden in de bijt, al is het maar doordat voor de behandeling van deze verzoeken wèl oproeping van de betrokken schuldeisers plaatsvindt.

Voor de inhoudelijke beoordeling van het verzoek bevat de wet enige voorwaarden voor toewijzing en een aantal imperatieve weigeringsgronden. Voor toewijzing dient voldoende aannemelijk te zijn (art. 288 lid I Fw):

a. dat de schuldenaar niet zal kunnen voortgaan met het betalen van zijn schulden (insolventie);

b. dat de schuldenaar t.a.v. het ontstaan of onbetaald laten van zijn schulden in de vijf jaar voorafgaand aan de dag waarop het verzoekschrift is ingediend, te goeder trouw is geweest (goede trouw-eis); en

c. dat de schuldenaar de uit de schuldsaneringsregeling voortvloeiende verplichtingen naar behoren zal nakomen en zich zal inspannen zoveel mogelijk baten voor de boedel te verwerven (inspanningsplicht).

De imperatieve afwijzingsgronden zijn - enigszins verkort weergegeven - de volgende (art. 288 lid 2):

a. de schuldsaneringsregeling is reeds van toepassing; 85

b. het minnelijk traject is niet uitgevoerd door een 'bevoegde' schuldhulpverlener;

8I. Dethmers, Van schuldsanering tot schone lei, p. 28-29. Polak-Polak, Faillissementsrecht, negende druk, 2002, p. 285 , gaat ervan uit dat behandeling in het openbaar dient plaats te vinden, nu het tegendeel (anders dan bij faillissement) niet is bepaald. M.i. zal openbare behandeling uitgangspunt moeten zijn, maar kan de rechter de deuren doen sluiten op grond van artikel 27 lid I onder c Rv. Afwijzing van het verzoek zonder de schuldenaar te horen acht ik in strijd met art. I9 Rv (en vermoedelijk ook art. 6 EVRM).

82. Aldus ook Polak-Polak, Faillissementsrecht, p. 285, E.F. Tjittes-Groot, Insolventierecht, 2004, p. 62, en A.R. van der Winkel en J.M. Marsman, Praktijkboek Insolventierecht, Schuldsaneringsregeling natuurlijke personen, 2008, p. 17. Anders voor afwijzende beslissingen: Dethmers, Van schuldsanering tot schone lei, p. 29. Ook uit het in 2008 toegevoegde art. 287 a lid 4 , tweede zin, Fw valt eerder op te maken dat alle uitspraken bij vonnis geschieden.

83. Aldus ook toelichting bij het Voorontwerp-Insolventiewet, p. 172.

84. Van deze voorlopige voorzieningen, gericht op voortzetting van het minnelijk traject, zijn te onderscheiden de voorlopige voorzieningen die kunnen worden gevraagd voor de duur van de behandeling van het wsnp-verzoek (art. 287 lid 4 Fw).

85. Een overbodige bepaling. 
c. de schuldenaar heeft schulden doordat hij terzake van een of meer misdrijven onherroepelijk is veroordeeld tot betaling van een geldboete, een bedrag tot ontneming van voordeel, een schadevergoedingsmaatregel dan wel een schadevergoeding aan de beledigde partij, indien de veroordeling binnen vijf jaar voor de indiening van het verzoekschrift onherroepelijk is geworden (tenzij de rechter aanleiding ziet om een langere termijn in acht te nemen).

d. de schuldsaneringsregeling is minder dan tien jaar geleden reeds toegepast op de schuldenaar.

De strenge goede trouw-eis en de verplichting tot afwijzing wegens strafrechtelijke schulden worden gemitigeerd doordat de rechter rekening mag houden met een keer ten goede: 'indien voldoende aannemelijk is dat de schuldenaar de omstandigheden die bepalend zijn geweest voor het ontstaan of onbetaald laten van zijn schulden, onder controle heeft gekregen' (art. 288 lid 3 Fw). Is de situatie van de schuldenaar inmiddels voldoende gestabiliseerd, en is bijvoorbeeld zijn verslaving onder controle, dan kan gezegd worden dat de schuldenaar 'er klaar voor is'. Toelating tot de wsnp is dan mogelijk. Deze hardheidsclausule is in 2008 toegevoegd onder druk van de Tweede Kamer, omdat geoordeeld werd dat de toelating anders al te streng zou worden beperkt.

Wijst de rechtbank het verzoek toe, dan benoemt zij een bewindvoerder en een rechter-commissaris en gelast zij dat de bewindvoerder gedurende dertien maanden kennis neemt van de post aan de schuldenaar (postblokkade) (art. 287 lid 3 en lid 5 Fw). Voorts heeft de rechter de mogelijkheid om te bepalen dat de schuldsaneringsregeling langer zal worden toegepast dan de standaardduur van drie jaar. Gebruikmaking van deze mogelijkheid in het toelatingsvonnis is echter uitzonderlijk (art. 349a lid I Fw). ${ }^{86}$ Het toewijzende vonnis wordt openbaar gemaakt door aankondiging in de Staatscourant en door registratie in het openbare schuldsaneringsregister (art. 293-294a Fw).

Met betrekking tot de regeling van rechtsmiddelen (art. $292 \mathrm{Fw}$ ) is van belang dat een schuldeiser niet in hoger beroep kan komen van een toewijzend vonnis, behalve voor zover het een toewijzing tegen hem betreft van een verzoek tot het geven van een bevel tot instemming met een minnelijke schuldregeling.

\subsection{De toepassing van de schuldsaneringsregeling}

De rechtsgevolgen van de schuldsaneringsregeling zijn voor een belangrijk deel gericht op inventarisatie van het vermogen en tegeldemaking ten behoeve van de schuldeisers. Deze verhaalsfunctie komt in hoge mate overeen met die van faillissement, ook al is de formulering hier en daar wat anders. Voor een ander deel, voor de schuldenaar belangrijker, is de regeling erop gericht de schuldenaar in staat te stellen en te stimuleren zich zodanig te gedragen dat hij in aanmerking kan komen voor

86. Voorts heeft de rechter de (eveneens zelden gebruikte) bevoegdheden om een datum voor de verificatievergadering vast te stellen, deskundigen te benoemen om een onderzoek naar de staat van de boedel in te stellen en daarvan verslag te doen, en/of voorzieningen te treffen die hij ter beveiliging van de belangen van de schuldeisers nodig oordeelt (artikelen 289 lid I, 29I en 290 Fw). 
een schone lei. Deze gedragsfunctie is uiteraard met de verhaalsfunctie verbonden in die zin, dat het van de schuldenaar verwachte gedrag gericht dient te zijn op het genereren van zoveel mogelijk baten voor de boedel. Voor het verkrijgen van een schone lei komt het hierbij aan op de inspanning, niet op het resultaat: ook schuldenaren die er niet in slagen voor hun schuldeisers te sparen, kunnen uiteindelijk een schone lei krijgen (vgl. art. 288 lid 4 Fw).

De verhaalsfunctie krijgt primair gestalte doordat aan de schuldenaar de beschikking over zijn vermogen wordt ontrokken ${ }^{87}$ en het beheer en de vereffening van de boedel worden opgedragen aan de bewindvoerder (art. 3i 6 lid I onder b Fw). De boedel strekt tot verhaal van vorderingen 'ten aanzien waarvan de schuldsaneringsregeling werkt', met name de vorderingen die reeds bestonden op het tijdstip van toelating tot de wsnp (art. $299 \mathrm{Fw}) .{ }^{88}$ Het collectieve verhaal komt in de plaats van individuele beslag- en executiemaatregelen van deze schuldeisers, voor zover zij tenminste geen separatist zijn (art. 299 lid 3, 30I Fw); voor nieuwe schulden van de schuldenaar is in beginsel geen verhaal op de boedel mogelijk (art. 24 jo. 3I3 lid I $\mathrm{Fw}$ ). Aan de bewindvoerder komen vergelijkbare bevoegdheden toe als aan de faillissementscurator, bijvoorbeeld op het punt van vernietiging van paulianeuze handelingen. Evenals in faillissement kan een afkoelingsperiode worden afgekondigd, waarin gedurende maximaal vier maanden verhaal of opeising van goederen die zich in de macht van de schuldenaar of de bewindvoerder bevinden, slechts met toestemming van de rechter-commissaris kan plaatsvinden (art. 3I3 lid I jo. 63a Fw).

Voor de schuldenaar betekent de benoeming van de bewindvoerder dat hij verlost is van de directe druk van zijn schuldeisers. De wet voorziet op passende wijze in bescherming van de 'thuissituatie' van de schuldenaar. Bewoont hij (of zij) een huurwoning, dan kan de huurovereenkomst tijdens de toepassing van de schuldsaneringsregeling niet worden opgezegd of ontbonden wegens achterstallige betalingen, daterend van vóór de toelating tot de wsnp (art. 305 Fw). Zelfs kan een reeds tegen de schuldenaar gewezen ontruimingsvonnis niet ten uitvoer worden gelegd, mits de lopende huurpenningen tijdig worden voldaan. Voor de duur van de schuldsaneringsregeling wordt de huurovereenkomst verlengd. ${ }^{89}$ Een vergelijkbare bescherming geniet de schuldenaar tegen staking van de aflevering van gas, water elektriciteit en verwarming (art. $304 \mathrm{Fw}$ ). Bewoont de schuldenaar een koopwoning, dan heeft de hypothecaire financier als separatist een sterke positie. Zonder nadere bepaling zou de separatist zijn recht veelal uitoefenen, ter voorkoming dat zijn vordering wordt getroffen door de schone lei. In de praktijk werd dit gevaar in sommige gevallen bezworen door met instemming van bewindvoerder en rechter-commissaris schuldvernieuwing overeen te komen. In 2008 is de wet zodanig gewijzigd, dat de rechter in het belang van de boedel kan bepalen dat over de vordering van de financier rente blijft lopen en dat de

87. Art. $296 \mathrm{Fw}$. Is er een gemeenschap van goederen, dan is deze gemeenschap eveneens onttrokken aan de beschikking van de andere echtgenoot/geregistreerde partner (art. 63 jo. 3I3 lid I Fw).

88. Uitzonderingen vormen bepaalde studieschulden (art. 299a Fw), hetgeen zal samenhangen met het feit dat deze vorderingen bestemd zijn om gedurende langere tijd niet-opeisbaar te zijn.

89. Strikt genomen zou de verhuurder direct na het einde van de toepassing van de schuldsaneringsregeling tot ontruiming kunnen overgaan, maar de wetgever is ervan uitgegaan dat als de schuldenaar intussen netjes aan zijn verplichtingen heeft voldaan, dit in de praktijk zo'n vaart wel niet zal lopen. 
vordering niet zal worden getroffen door de schone lei (art. 303 lid 3, 358 lid 5 Fw). Door de hypotheekrente te blijven voldoen, kan de schuldenaar zijn woning dan behouden. Daarnaast blijft ook de inboedel van de schuldenaar, voor zover niet bovenmatig, ${ }^{\circ}$ buiten de boedel (art. 295 lid 4 onder b Fw).

Van de inkomsten van de schuldenaar blijft volgens artikel 295 leden 3 en 4 Fw in ieder geval buiten de boedel een bedrag dat overeenkomst met de wettelijke beslagvrije voet, d.w.z. een bedrag dat overeenkomt met 90\% van het bedrag van de voor de schuldenaar geldende bijstandsnorm, rekening houdend met de samenstelling van zijn huishouden. De rechter-commissaris kan dit bedrag verhogen met een nominaal bedrag. In de praktijk vindt verhoging altijd plaats, door toepassing van een 'rekenmodel vrij te laten bedrag' (vtlb), dat is ontwikkeld door een werkgroep van Recofa (rechters-commissarissen in faillissementen). Grof gezegd wordt in alle gevallen een reserveringstoeslag toegekend van van $5 \%$ van de bijstandsnorm en voorts voor schuldenaren die een baan hebben een arbeidstoeslag van nog eens $5 \%$. Men zou hierin tevens een element kunnen zien van het 'stok achter de deur'-effect van de wet: voor schuldeisers is immers buiten de wsnp verdergaand verhaal mogelijk op het inkomen van de schuldenaar. In het minnelijk traject wordt tegenwoordig echter, naar ik heb begrepen, eveneens veel gebruik gemaakt van de rekenmethode van Recofa, ${ }^{9 \mathrm{I}}$ hetgeen dit effect verkleint. Net als in faillissement zijn ook voorzieningen voor toekomstig inkomen in de vorm van levensverzekeringen tegen uitwinning beschermd (art. 295 lid 6 jo. $22 \mathrm{a} \mathrm{Fw).} .^{92}$

De schuldenaar verliest door de toelating tot de wsnp noch zijn handelingsbekwaamheid, noch zijn handelingsbevoegdheid. Het laatste is, anders dan in faillissement, met zoveel woorden bepaald, met enige bijzonderheden ter bescherming van de schuldenaar (art. $297 \mathrm{Fw}$ ). ${ }^{93}$ In hetzelfde beschermingslicht kan de regel worden gezien dat betalingen door de schuldenaar uit zijn vrijgelaten goederen op vorderingen waarvoor de schuldsaneringsregeling werkt, nietig zijn (art. $306 \mathrm{Fw}$ ). Bescherming van de schuldenaar tegen onverantwoorde uitgaven kan worden bereikt door een vorm van budgetbeheer, welke door de rechter-commissaris kan worden opgelegd (art. 310 Fw). ${ }^{94}$

Om zijn schone lei te verdienen, dient de schuldenaar te voldoen aan een aantal verplichtingen. Oorspronkelijk voorzag de wet in een saneringsplan, waarin concrete verplichtingen konden worden opgenomen. Omdat het saneringsplan in

90. Het begrip 'bovenmatig' zou op zichzelf aanleiding kunnen geven tot enige onduidelijkheid. Jurisprudentie daarover is mij echter niet bekend.

9I. Maar dan zonder de arbeidstoeslag.

92. De bescherming is gericht op het voorkomen van 'onredelijke benadeling' van verzekeringnemer of begunstigde, welke het gevolg zou zijn van verlies van aanspraken met een verzorgingskarakter. Daartoe vallen - voor zover nodig om onredelijke benadeling te voorkomen - het recht om de verzekering te doen afkopen of om de begunstiging te wijzigen buiten de boedel. Het recht om de polis te belenen valt geheel buiten de boedel.

93. De uitzonderingen betreffen het aangaan van een kredietovereenkomst, het zich verbinden als borg of medeschuldenaar e.d., en het doen van ongebruikelijke of bovenmatige giften.

94. Dethmers, Van schuldsanering tot schone lei, p. 56, vermeldt dat deze vorm van budgetbeheer slechts zelden wordt toegepast, in tegenstelling tot vormen van contractueel budgetbeheer met bijvoorbeeld een gemeentelijke kredietbank. 
de praktijk niet als zinvol werd ervaren, is het met ingang van 2008 afgeschaft. De volgende verplichtingen kunnen worden onderscheiden:

- het afdragen aan de bewindvoerder van al het in de boedel vallende inkomen en vermogen (art. 296 lid 2 Fw);

- $\quad$ het optimaliseren van de boedelafdrachten (sinds 2008 gecodificeerd in 288 lid I onder $\mathrm{c} \mathrm{Fw}$ ), hetgeen zowel het beperken van uitgaven omvat als het vergroten van inkomsten, zo nodig door (beter betaald) werk te zoeken;

- het steeds verschaffen van alle relevante inlichtingen, zo nodig uit eigen beweging (art. I05 jo. 327 Fw, alsmede HR I5 februari 2002, NJ 2002, 259);

- $\quad$ het niet doen of laten ontstaan van nieuwe (bovenmatige) schulden (art. 350 lid 3 onder d);

- $\quad$ het niet benadelen van schuldeisers (art. 350 lid 3 onder e Fw);

- het niet belemmeren of frustreren van de uitvoering van de schuldsaneringsregeling (art. 350 lid 3 onder c Fw), door zich bijvoorbeeld niet te houden aan gemaakte afspraken of door de bewindvoerder te bedreigen (vgl. Hoge Raad Io januari 2003, NJ 2003, I95). 95

\subsection{Einde van de toepassing van de schuldsaneringsregeling}

Voor de verificatie van vorderingen en de mogelijkheid van het aanbieden van een akkoord geldt tot op grote hoogte hetzelfde als in faillissement. De voornaamste bijzonderheid is erin gelegen dat bij uitdelingen (hoger) preferente schuldeisers geen absolute voorrang hebben boven (lager preferente en) concurrente schuldeisers: in plaats daarvan ontvangen preferente schuldeisers bij uitkeringen (slechts) een twee keer zo hoog percentage op hun vordering dan concurrente schuldeisers (art. 349 lid $2 \mathrm{Fw}$ ). In verband daarmee is een akkoord ook verbindend voor preferente schuldeisers en stemmen zij daarover (in een aparte groep) mee: art. $332 \mathrm{Fw}$. Een verificatievergadering kan ook 'slechts pro forma' worden gehouden, als bij geen der schuldeisers geen belangstelling bestaat daadwerkelijk te verschijnen (art. 328a Fw).

De regeling voor het einde van de toepassing van de schuldsaneringsregeling is niet gemakkelijk leesbaar (artikelen 349a-358 Fw). Zij komt neer op het volgende.

Een tussentijdse beëindiging kan worden uitgesproken op initiatief van de bewindvoerder of een schuldeiser, dan wel van de schuldenaar zelf of de rechter-commissaris. Gevolg daarvan is dat de schuldenaar geen schone lei krijgt. Dit doet zich voor als alle schulden zijn voldaan of de schuldenaar in staat is zijn betalingen te hervatten, dan wel als de schuldenaar voortzetting van de regeling niet meer ziet zitten (art. 350 lid 3 onder a, b en $g$ Fw). Tussentijdse beëindiging zonder schone lei is ook mogelijk als de schuldenaar zijn hiervoor omschreven verplichtingen niet nakomt of als er feiten aan het licht zijn gekomen die reden zouden zijn geweest de toelating tot

95. Met Dethmers, Van schuldsanering tot schone lei, p. 52, acht ik de schuldenaar in dit kader gehouden tot een coöperatieve opstelling en fatsoenlijk gedrag. 
de wnsp te weigeren..$^{6}$ In deze gevallen komt de schuldenaar van rechtswege in staat van faillissement te verkeren, mits er baten beschikbaar zijn.

Tegenover de tussentijdse beëindiging staat de beëindiging wegens het verstreken zijn van de vastgestelde duur van de toepassing van de regeling (drie tot maximaal vijf jaar). Er vindt een beoordeling plaats van de vraag of de schuldenaar in de nakoming van zijn verplichtingen is tekortgeschoten en, zo ja, of dit aan hem kan worden toegerekend. Toerekenbare tekortkomingen kunnen buiten beschouwing blijven als zij van bijzondere aard of geringe betekenis zijn. Als het hiervoor op te maken verslag van de bewindvoerder geen reden tot twijfel geeft of de schone lei kan worden verleend, kan de rechtbank beslissen zonder de bewindvoerder en de schuldenaar op te roepen. Afhankelijk van het oordeel over de wijze waarop de schuldenaar zich van zijn verplichtingen heeft gekweten, beëindigt de rechtbank de toepassing van de regeling met of zonder schone lei; de toepassing kan (binnen het maximum van vijf jaar) ook verlengd worden om de schuldenaar alsnog uitzicht te bieden op een schone lei. Als de beëindigingsuitspraak onherroepelijk is geworden en er uitgedeeld moet worden, maakt de bewindvoerder een slotuitdelingslijst op.

Voor schuldenaren zonder spaarcapaciteit bestaat de mogelijkheid van een verkorte afwikkeling van de regeling (art. 354a Fw). Vereist is dat de regeling ten minste gedurende een jaar is toegepast en dat de bewindvoerder verklaart dat 'redelijkerwijs niet de verwachting bestaat dat de schuldenaar op zodanige wijze aan zijn verplichtingen kan voldoen dat voortzetting van de schuldsaneringsregeling gerechtvaardigd is'. Daarmee wordt dus bedoeld dat de schuldenaar hoogstwaarschijnlijk (nagenoeg) niets meer zal kunnen afdragen aan de boedel. 97

Met het verbindend worden van de slotuitdelingslijst dan wel, als er geen uitdeling zal plaatsvinden, het onherroepelijk worden van de beëindigingsuitspraak, eindigt de toepassing van de schuldsaneringsregeling.

De schone lei houdt in dat de vorderingen waarvoor de schuldsaneringsregeling werkt, voor het onvoldaan gebleven restant niet langer afdwingbaar zijn, onverschillig of de schuldeisers zijn opgekomen en of de vorderingen zijn geverifieerd. Boedelschulden blijven wél afdwingbaar tegen de schuldenaar, behalve als het gaat om boedelschulden uit een direct aan de toepassing van de wsnp voorafgegaan failissement. ${ }^{98}$ Van de schone lei uitgesloten zijn de strafrechtelijke vorderingen die hiervoor reeds ter sprake zijn geweest, alsmede door de civiele rechter vastgestelde schadevergoedingsvorderingen na verwijzing door de strafrechter (art. $35^{8}$ lid 4 Fw).

96. Tussentijdse beëindiging kan niet worden gegrond op feiten en omstandigheden die ten tijde van de beslissing tot toepassing van de schuldsaneringsregeling aan de rechter bekend waren (Hoge Raad 5 september 2008, LJN: BD3425; sinds de wijziging van 2008 blijkt het uitdrukkelijk uit art. 350 lid 3 onder $\mathrm{f} \mathrm{Fw).} \mathrm{Daarmee} \mathrm{zou} \mathrm{aan} \mathrm{schuldeisers} \mathrm{immers} \mathrm{indirect} \mathrm{een} \mathrm{rechtsmiddel} \mathrm{worden}$ toegestaan dat de wetgever hun nu juist niet heeft willen bieden (art. 292 lid 2 Fw).

97. De wet gaat er in art. $356 \mathrm{Fw}$ vanuit dat bij deze verkorte afhandeling geen slotuitdelingslijst behoeft te worden opgemaakt. Dat lijkt mij niet altijd juist: er kunnen gevallen zijn dat er wel (enig) geld in de boedel voor uitdeling beschikbaar is, maar van de schuldenaar geen verdere afdrachten verwacht kunnen worden.

98. Art. $35^{8}$ lid 3 Fw. Dit is een wat verwarrende bepaling, geschreven voor gevallen dat een ondernemer niet direct toelating verkrijgt tot de wsnp, omdat zijn onderneming onvermijdelijk nog tot enige (boedel)schulden zal leiden. De omweg van een faillissement zou hier m.i. niet nodig moeten zijn. 
Ook de vordering van een hypothecaire financier kan, zoals hiervoor aan de orde kwam, buiten de schone lei vallen (art. 358 lid 5 Fw).

Als achteraf blijkt dat de schuldenaar tijdens de toepassing van de schuldsaneringsregeling heeft getracht schuldeisers te benadelen, kan op verzoek van iedere belanghebbende worden bepaald dat de schone lei verder geen toepassing vindt (art. $358 \mathrm{a} \mathrm{Fw})$.

\section{$6 \quad$ Nader over de toegang}

Voor de rechter die moet beslissen over toelatingsverzoeken van de schuldenaar, dienen zich twee te onderscheiden aandachtsgebieden aan: in de eerste plaats het minnelijk traject en in de tweede plaats de schuldenaar. Over beide aandachtsgebieden maak ik enige opmerkingen.

\section{I Het minnelijk traject}

$\mathrm{Bij}$ het verzoek om toelating dient een met redenen omklede verklaring te worden overgelegd dat er geen reële mogelijkheden zijn om tot een buitengerechtelijke schuldregeling te komen, alsmede over welke aflossingsmogelijkheden de verzoeker beschikt (art. 285 lid I onder f Fw). De verklaring dient te worden verkregen van het college van burgemeester en wethouders, dan wel van een door dit college gemandateerde instelling. In de praktijk wordt de verklaring opgesteld aan de hand van een daartoe ontwikkeld model. Met de vereiste verklaring heeft de wetgever een zekere drempel willen leggen, om te voorkomen dat schuldenaren in het minnelijk traject te snel het bijltje erbij neergooien. De tot afgifte bevoegde instantie heeft niet de bevoegdheid haar medewerking te weigeren (art. 285 lid 2 Fw), hetgeen bestuursrechtelijke rechtsbescherming daartegen overbodig heeft moeten maken. ${ }^{99}$ In de praktijk kan met de afgifte overigens geruime tijd gemoeid zijn. Tot 2008 had de rechter de bevoegdheid de schuldenaar toe te laten indien de verklaring in redelijkheid niet geweigerd had mogen worden. Daaruit zou men kunnen afleiden dat er gevallen zijn waarin die medewerking wèl geweigerd mag worden, bijvoorbeeld als de aangezochte instantie meent dat er wèl reële mogelijkheden zijn voor een minnelijke regeling. ${ }^{\text {IOO }}$ Afgifte van de verklaring overenkomstig het gehanteerde model behoeft $\mathrm{m}$.i. niet te impliceren dat er inderdaad in het minnelijk traject geen reële mogelijkheden meer bestaan. De mogelijkheid om het verzoek ook zonder verklaring toe te wijzen, is inmiddels vervallen: zo nodig zal de schuldenaar een nieuw verzoek kunnen doen, als hij later alsnog over de verklaring beschikt. Een en ander zal met name aan de orde kunnen zijn in gevallen dat het wsnp-verzoek wordt

99. Die is dan ook uitgesloten in de bijlage bij de Algemene wet bestuursrecht.

I0o. Zie voor een geval dat afgifte van een verklaring geweigerd werd Rechtbank Rotterdam 23 juli 2004, Jaarboek Schuldsanering 2006, nr. 204. Lankhorst schrijft in zijn commentaar dat de verklaring niet - op welke inhoudelijke grond dan ook - geweigerd mag worden, omdat die instantie dan in feite op de stoel van de rechter gaat zitten. Op de website van de Raad voor rechtsbijstand 's-Hertogenbosch wordt nog steeds vermeld dat in de praktijk medewerking soms wordt geweigerd. 
gedaan in reactie op een faillissementsverzoek door een schuldeiser. In de Recofarichtlijnen wordt voor gevallen dat het wsnp-verzoek is gedaan door een schuldenaar die reeds in staat van faillissement verkeert (art. $15 \mathrm{~b} \mathrm{Fw}$ ), bepaald dat overlegging van een 285 -verklaring niet nodig is. ${ }^{\text {IOI }}$

Gelet op het grote belang dat gehecht wordt aan het minnelijk traject, is het opvallend dat van de rechter geen inhoudelijk oordeel wordt verlangd dat er inderdaad geen reële mogelijkheden om tot een buitengerechtelijke schuldregeling te komen. Volstaan kan worden met toetsing van de aanwezigheid van de 285 -verklaring, toetsing van de inhoud is niet voorgeschreven: 'De verklaring is een instrument om ervoor te zorgen dat eerst een buitenwettelijke oplossing wordt beproefd. De rechtbank behoeft zich niet van de juistheid van de verklaring te overtuigen. Indien de verklaring naar het oordeel van de rechtbank onvoldoende met redenen is omkleed, kan de rechtbank de verklaring [leest: toelating] weigeren. ${ }^{\text {,O2 }}$ Dit 'formalisme' blijkt ook uit de in 2008 ingevoerde verplichting om het verzoek af te wijzen als het minnelijk traject niet is uitgevoerd door een persoon of instelling als bedoeld in art. 48 lid I van de Wet op het consumentenkrediet. Schuldhulp door bijvoorbeeld de werkgever of een kerk valt daarbuiten, ongeacht de inhoudelijke kwaliteit van de geboden hulp. Certificering van de schuldhulpverlening zal, zo schreef ik eerder al, vermoedelijk in 2009 worden gerealiseerd.

De rechter zal zich niet kunnen onttrekken aan een inhoudelijke beoordeling van het minnelijk traject als de schuldenaar in zijn verzoekschrift heeft verzocht om een voorlopige voorziening in de zin van artikel $287 \mathrm{~b}$ Fw. Een dergelijke voorziening is er namelijk op gericht alsnog in het minnelijk traject voort te werken aan een buitengerechtelijke schuldregeling. De regeling is bedoeld voor gevallen dat zich voorafgaand aan het verzoek een 'bedreigende situatie' voordoet, dat wil zeggen gedwongen woningontruiming, beëindiging van de levering van gas, elektra of water of opzegging dan wel ontbinding van de zorgverzekering. De rechter kan de bescherming die de schuldenaar bij toepassing van de wettelijke schuldsaneringsregeling geniet tegen nutsleveranciers en tegen zijn verhuurder (artikelen 304 en 305) voor maximaal zes maanden van toepassing verklaren en voorts kan hij voor dezelfde periode opzegging of ontbinding van zorgverzekeringen verbieden. Aanvankelijk voorzag het amendement dat aan de regeling ten grondslag ligt ook in opheffing van gelegde beslagen. Omdat de schuldenaar echter bij beslag al wordt beschermd door de beslagvrije voet en opheffing van beslagen voor schuldeisers in het minnelijk traject - gelet op de beschikkingsbevoegdheid van de schuldenaar - zeer nadelig kan uitpakken, is dat laatste uiteindelijk weggelaten. ${ }^{\text {I03 }}$

In de vierde monitor wsnp is vermeld dat in de eerste vier maanden bij 16 van de I 9 rechtbanken 148 verzoeken om een voorlopige voorziening ex art. $287 \mathrm{~b}$ Fw zijn ingediend, waarvan er 73 zijn toegewezen. Het aantal afwijzingen en niet-ontvankelijk-

IoI. A.R. van der Winkel, J.M. Marsman, Praktijkboek Insolventierecht, Schuldsanering natuurlijke personen, tweede druk, 2008, p. 64.

I02. Aldus de memorie van toelichting bij de novelle, Kamerstukken II I997/98, 25 672, nr. 3, p. 4. Dat de afgevende instantie met een weigering op inhoudelijke gronden op de stoel van de rechter gaat zitten, zoals Lankhorst meent (Jaarboek Schuldsanering 2006, nr. 204), is dus eigenlijk niet juist.

I03. Juist wegens dit onderdeel had de minister van Justitie zich sterk tegen het amendement verzet. 
verklaringen bedroeg I4 resp. 2I, en daarnaast werden 27 verzoeken ingetrokken en

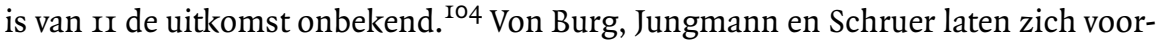
zichtig optimistisch uit over de nieuwe middelen die de wet sinds 2008 biedt, waaronder dit 'moratorium'. ${ }^{105}$ In de praktijk lijkt verder geen groot probleem te worden gemaakt van de wat ongelukkige formulering van deze regeling, die naar de letter alleen lijkt te kunnen worden toegepast samen met een verzoek om een schuldeiser te bevelen mee te werken aan een aangeboden schuldregeling (art. 287a Fw). ${ }^{\text {I06 }}$

Het zojuist genoemde voorzichtig optimisme heeft mede betrekking op de regeling van het dwangakkoord van art. 287a Fw. De vrees dat het Payroll-arrest de effectiviteit van dit middel bij voorbaat zou ondergraven, is totnogtoe gelukkig niet bewaarheid. Niettemin moet in het oog worden gehouden dat de grondslag van de regeling (misbruik van recht) de bevoegdheid van schuldeisers vooronderstelt om wel of niet in te stemmen met een aangeboden regeling. De door de Hoge Raad gegeven uitgangspunten voor de beoordeling, laten de rechter slechts beperkte ruimte om schuldeisers tot medewerking te verplichten. Wil men dit anders, dan kan een regeling worden overwogen als in het Voorontwerp-Insolventiewet, waarbij de schuldeisers over een aangeboden schuldregeling kunnen stemmen (en overstemd worden).

\subsection{Beoordeling van de schuldenaar}

Hiervoor is reeds melding gemaakt van de in art. $288 \mathrm{Fw}$ geformuleerde regels voor toewijzing van wsnp-verzoeken. Op enkele daarvan, zoals de eis dat de schuldenaar niet zal kunnen voortgaan met het betalen van zijn schulden, dat de schuldsaneringsregeling niet reeds van toepassing is of minder dan tien jaar geleden van toepassing is geweest, ga ik hier niet nader in. Wel wil ik ingaan op de eisen dat de goede trouw van de schuldenaar voldoende aannemelijk is (lid I onder b) en dat voldoende aannemelijk is dat hij de uit de regeling voortvloeiende verplichtingen naar behoren zal nakomen (lid I onder c). Op beide punten heeft de wetgever met de wijzigingen van 2008 strengere eisen willen stellen.

Vóór 2008 kon het verzoek worden afgewezen indien aannemelijk was dat de schuldenaar ten aanzien van het ontstaan of onbetaald laten van schulden niet te goeder trouw was geweest. Thans dient voor toewijzing voldoende aannemelijk te zijn dat de schuldenaar ten aanzien van het ontstaan of onbetaald laten van zijn schulden in de vijf jaar voorafgaand aan het verzoek te goeder trouw is geweest. Van een grond op grond waarvan kon worden afgewezen, is goede trouw een positieve voorwaarde voor toewijzing geworden. Bij deze wijziging heeft een rol gespeeld dat de Hoge Raad bij afwijzende beslissingen hoge motiveringseisen heeft gesteld. Niet alleen wilde de wetgever de met deze motiveringsplicht gemoeide belasting voor de rechter

I04. Vierde monitor wsnp, 2008, p. 32.

I05. I.R. von Burg, N. Jungmann en H.D.L.M. Schruer, 'Met gepaste dwang: minnelijke middelen in de Wsnp na I januari 2008', Schuldsanering april 2008, p. I-4.

ı66. Vgl. J.H.M. von den Hoff, 'Toepassing nieuwe Wsnp-instrumenten nog niet zo simpel', Schuldsanering april 2008, p. 4-7, die enige haken en ogen bespreekt, maar de hoop uitspreekt dat daarvoor in de rechtspraak praktische oplossingen worden gevonden. 
verlichten. De wijziging werd ook ingegeven door 'de indruk' dat daardoor meer schuldenaren in de schuldsaneringsregeling terechtkwamen dan nodig. ${ }^{107}$

De ruimte ontbreekt mij om erg diep in te gaan op de goede trouw-eis. Daarvoor kan ik de lezer verwijzen naar het omvangrijke proefschrift van Noordam over dit onderwerp. ${ }^{\text {Io8 }}$ Een handzame samenvatting ontleen ik aan Van Buchem-Spapens en Pouw:

'Bij goede trouw in de schuldsaneringsregeling gaat het niet om goede trouw in de zin van art. 3:II BW of om de redelijkheid en billijkheid van art. 6:2 of $248 \mathrm{BW}$, maar om een gedragsmaatstaf: te goeder trouw handelen (zie bijvoorbeeld ook art. $54 \mathrm{Fw}$ ). Uit de wetsgeschiedenis blijkt dat de rechter in een concreet geval met alle omstandigheden rekening kan houden. De MvT geeft als voorbeelden: de omvang van de schulden en de mate waarin de schuldenaar er een verwijt van kan worden gemaakt dat die zijn ontstaan en geheel of gedeeltelijk onbetaald zijn gebleven, de situatie dat de schuldenaar verhaalsacties van de schuldeisers heeft gefrustreerd of geprobeerd heeft dat te doen, het tijdstip waarop en de frequentie waarin de schulden zijn gemaakt, het betalingsgedrag van de schuldenaar en eventuele pogingen om zijn schulden te doen verminderen. Ook de Hoge Raad heeft al een aantal malen benadrukt dat het gaat om een gedragsmaatstaf. De rechter heeft daarom een zekere beoordelingsvrijheid en mag inderdaad rekening houden met alle omstandigheden van het geval.' ${ }^{\text {Io9 }}$

Dat laatste mag de rechter niet alleen: indien de schuldenaar bepaalde omstandigheden aanvoert op grond waarvan hij - in weerwil van een ontbreken van goede trouw t.a.v. bepaalde schulden - toegelaten behoort te worden, moet de rechter daarmee rekening houden en daarvan in zijn motivering blijk geven (HR I2 mei 2000, NJ 2000, 567 en voorts HR 26 januari 200I, NJ 200I, I78). In de oorspronkelijke opzet, waarin de goede trouw-toets slechts een facultatieve afwijzingsgrond vormde, kan de rechter inderdaad bezwaarlijk volstaan met de constatering dat de goede trouw t.a.v. een bepaalde schuld ontbrak als daartegenover argumenten staat die vóór toelating pleiten.

Het valt op dat de wetsgeschiedenis over de strekking van de goede trouw-eis niet erg duidelijk is. In de memorie van toelichting wordt vermeld dat de eis van diverse zijden is bepleit in reactie op het voorstel van de Commissie Mijnssen om géén goede trouw-toets op te nemen. In die reacties werd de eis in verband gebracht met de mogelijkheid om misbruik te bestrijden. ${ }^{\text {IIO }}$ De memorie van antwoord vermeldt dat de eis werd gesteld 'mede om het mogelijk te maken misbruik van de regeling tegen te gaan'. ${ }^{\text {III }}$ Welk ander doel eraan ten grondslag ligt, blijft ongenoemd. Een moreel aspect lijkt aanwezig: de mogelijkheid van een schone lei wordt op morele gronden onthouden aan schuldenaren die haar niet 'verdienen'. Sommigen drukken dit aldus uit, dat de schuldenaar geen 'recht' heeft op een schone lei, omdat deze als het ware een 'gunst' vormt van de overheid c.q. de samenleving aan de ongelukkige

I07. Aldus de memorie van toelichting, Kamerstukken II 2004-2005, 29 942, nr. 3, p. 4-5.

I08. Noordam, Schuldsanering en goede trouw (meer dan 700 pagina's).

I09. Van Buchem-Spapens en Pouw, Faillissement, surseance van betaling en schuldsanering, p. I3II32. Deze samenvatting is voor een belangrijk deel ontleend aan HR I2 mei 2000, NJ 2000, 567, welk arrest op zijn beurt mede gebaseerd is op de wetsgeschiedenis.

IIo. Kamerstukken II I992-I993, 22 969, nr. 3, p. I2-I4.

III. Kamerstukken II I992-I993, 22 969, nr. 6, p. 20. 
schuldenaar. ${ }^{\mathrm{II} 2}$ Hoewel ik meen dat als de schuldenaar een ernstig verwijt treft van het ontstaan of onbetaald laten van één of meer van zijn schulden, een schone lei moet kunnen worden geweigerd, is het niet gelukkig om te spreken van een gunst. Niet alleen wordt de toetsbaarheid van de rechterlijke beslissing dan problematisch, maar ook - belangrijker - doet dat geen recht aan de maatschappelijke overwegingen die ten grondslag liggen aan de sanering van schulden van burgers in problematische schuldsituaties. Meer thuis voel ik mij bij de opvatting van Van Schilfgaarde in zijn NJ-noot onder het arrest van 12 mei 2000: de gedachte lijkt te zijn dat het niet veel zin heeft de regeling toe te passen op iemand van wie men, gelet op zijn verleden, niet kan verwachten dat hij zich daaraan houdt. Per saldo houdt volgens hem de gedragsmaatstaf een 'op prognose gerichte moraliteitstest' in.

In latere jurisprudentie is de Hoge Raad ervan blijven uitgaan dat de gedragsmaatstaf van de goede trouw op allerlei gedragingen betrekking kan hebben, en derhalve niet slechts op gedragingen in de financiële sfeer of gedragingen waarbij de schuldenaar zich bewust was dat schulden ontstonden of onbetaald bleven (HR Io januari 2003, NJ 2003, I95). Anderzijds mag de rechter een wsnp-verzoek niet afwijzen indien niet kan worden beoordeeld of de schuldenaar te goeder trouw is geweest (HR I7 december 2004, NJ 2005, 240; HR 6 april 2007, NJ 2007, 206). Tot de overige omstandigheden die van belang kunnen zijn bij de vraag of een ontbreken van goede trouw aan toelating in de weg staat, rekent de Hoge Raad ook het ontstaan en het beloop van de overige schulden, hetgeen van belang kan zijn als de schuldenaar slechts ten aanzien van een zeer klein deel van de totale schuldenlast niet te goeder trouw is geweest (HR 20 april 2007, NJ 2007, 242).

Met de wijzigingen van 2008 heeft de wetgever beoogd strengere toelatingscondities te stellen. Daarbij ging hij niet uit van een gewijzigde opvatting omtrent het begrip goede trouw als zodanig: wel zou de rechter het verzoek moeten afwijzen zodra goede trouw ontbreekt. ${ }^{\mathrm{II} 3}$ Men zou dus kunnen verwachten dat de rechter niet meer, als voorheen, rekening hoeft te houden met allerlei omstandigheden van het geval die de schuldenaar aanvoert ten betoge dat hij ondanks mogelijk ontbreken van goede trouw dient te worden toegelaten tot de wsnp. Maar vreemd genoeg benadrukt de regering óók dat de goede trouw dient te worden getoets met inachtneming van alle omstandigheden van het geval. ${ }^{\mathrm{II} 4} \mathrm{Om}$ een voorbeeld te geven: mag de rechter de schuldenaar nu wel of niet toelaten als deze een aanzienlijke schuldenlast heeft, waarvan een slechts zeer klein deel het gevolg is van opzettelijke (recente) verkeersovertredingen en derhalve niet te goeder trouw is ontstaan (de casus van HR 20 april 2007, NJ 2007, 242)? Leidt de vaststelling dat de schuldenaar t.a.v. het ontstaan van een deel van zijn schulden niet te goeder trouw is geweest, automatisch tot afwijzing, of kunnen andere omstandigheden van het geval alsnog tot een posi-

II2. Die benadering vinden terug bij de toenmalige minister van Justitie Donner, die een stelsel wilde waarin 'schuldsanering geen aanspraak maar een mogelijkheid is, mits aan een aantal voorwaarden is voldaan' (Kamerstukken II 2002-2003, 28 258, nr. 6, p. I). Op vergelijkbare wijze vormde voor Hugo de Groot boedelafstand een 'weldaed dat van de hooge overeid werd verworden' (geciteerde bij Noordam, Schuldsanering en goede trouw, p. I49) en werd ook de surseance van betaling vroeger wel gezien als een gunst (beneficie) van de soeverein (vgl. bv. Van der Feltz II, p. 338).

II3. Kamerstukken II 2005-2006, 29 942, nr. 7 (nota n.a.v. het verslag), p. 57.

II4. Vgl. over deze onduidelijkheid Noordam, Schuldsanering en goede trouw, p. 493. 
tieve beslissing leiden? Het laatste valt te hopen, maar ik ben er niet zeker van. ${ }^{\mathrm{II} 5}$ In elk geval ga ik ervan uit dat de motiveringsplicht van de rechter t.a.v. de aannemelijkheid van goede trouw, minder ver gaat dan de motiveringsplicht onder het oude recht t.a.v. de vraag of de schuldenaar ondanks ontbreken van goede trouw toch toegelaten diende te worden. ${ }^{\text {II }}$ De jurisprudentie dat de omstandigheid dat niet kan worden vastgesteld of de schuldenaar te goeder trouw is geweest, niet voor risico van de schuldenaar mag komen, lijkt mij achterhaald.

In het kader van de gewenste strengere toelatingscondities dient het wsnp-verzoek in elk geval te worden afgewezen als de schuldenaar schulden heeft die voortvloeien uit een veroordeling voor een misdrijf, die minder dan vijf jaar voor het verzoek onherroepelijk is geworden. Langer (en dus strenger) mag ook, als de rechter daarvoor aanleiding ziet (art. 288 lid 2 onder c Fw). Met deze regeling is codificatie beoogd van het rechterlijk beleid dat op dit punt was ontstaan.

In het parlement bleek al deze strengheid evenwel teveel van het goede. Gevreesd werd dat de wnsp onbereikbaar zou worden voor schuldenaren aan wie op zichzelf verwijten konden worden gemaakt van hun schulden, maar die inmiddels een keer ten goede hadden gemaakt. Met name werd gedacht aan mensen met psychosociale of verslavingsproblemen. Als gevolg van een amendement kan een schuldenaar die de omstandigheden die bepalend zijn geweest voor het ontstaan of onbetaald laten van zijn schulden (lees: de verslaving), onder controle heeft gekregen, toch worden toegelaten tot de schuldsanering (art. 288 lid $_{3} \mathrm{Fw}$ ). Uitgangspunt van is een periode van één jaar, afhankelijk van de ernst en de duur van de verslaving. Met deze hardheidsclausule zijn de scherpe kanten van de wetswijziging verzacht. Vast staat dat de schuldenaar ondanks ontbreken van goede trouw het uitzicht op een schone lei kan herwinnen door middel van een concrete gedragsverandering. De formulering van de bepaling is zodanig ruim, dat toepassing ook denkbaar is in andere omstandigheden dan psychosociale of verslavingsproblemen. ${ }^{\text {II7 }}$

De regel dat goede trouw van de schuldenaar t.a.v. het ontstaan of onbetaald laten van zijn schulden aannemelijk dient te zijn voor toelating tot de schuldsanering, vormt geen sanctie op onjuist gedrag. Wel is zij verklaard vanuit de gedachte dat uit het gedrag van de schuldenaar in het verleden een prognose volgt voor zijn vermogen om de schuldsanering met vrucht te doorlopen. Maar daarnaast is zij ook, in 2008 meer dan in 1998 , op te vatten als een morele voorwaarde, gesteld omdat een schone lei maatschappelijk moeilijk aanvaardbaar geacht wordt als de schuldenaar zijn schuldenlast te wijten heeft aan ernstig laakbaar gedrag. Hier is wel een evenwicht nodig, om te voorkomen dat de toelatingseisen onrealistisch hoog worden gesteld. Daarmee zou de doelstelling in het gedrang komen dat schuldenaren een

II5. Hoop valt te putten uit de Recofa-richtlijnen, waar in onderdeel 7a als contra-indicatie voor goede trouw de aanwezigheid van substantiële geldboetes ter zake van verkeersovertredingen wordt vermeld.

II6. Maar daarover wordt ook anders gedacht. Zo begrijp ik althans Dethmers, 'De schuldsaneringsregeling processueel benaderd', p. 92.

II7. Dat is kennelijk ook de opvatting van voormalig Recofa-voorzitter B. Engberts, 'Het wetsontwerp Wsnp (deel 3): Akkoord, rol rechter-commissaris, eindzitting, faillissement na Wsnp, schone lei nieuwe stijl en overgangsrecht', Schuldsanering $2007 / 4$, p. 9. 
perspectief geboden moet worden van een schuldenvrije toekomst ('fresh start'). En voorts zou dat een negatieve uitstraling kunnen hebben op het minnelijk traject.

Acht men de goede trouw-toets onmisbaar, dan ligt naar mijn oordeel een terughoudend gebruik ervan voor de hand. Daartoe is ook geadviseerd door de Commissie insolventierecht. In het commentaar van de Nederlandse Vereniging voor Rechtspraak op het Voorontwerp-Insolventiewet wordt echter vastgehouden aan de huidige praktijk, onder meer omdat het beoordelen van de goede trouw in de praktijk 'geen groot probleem' is en van een wijziging een toename van insolventiezaken en daarmee een stijging van werklast wordt gevreesd. ${ }^{118}$ Hoe lastig een dergelijke beoordeling is, blijkt wel uit het feit dat de Recofa-voorzitter Engberts in 2007 nog meende dat de wijzigingen in de goede trouw-toets noodzaakten tot een omslachtige en tijdrovende werkwijze. ${ }^{\text {II } 9}$

Naast de goede trouw-toets dient voor toelating tot de schuldsaneringsregeling ook voldoende aannemelijk te zijn dat de schuldenaar zijn uit de regeling voortvloeiende verplichtingen naar behoren zal nakomen en zich zal inspannen zoveel mogelijk baten voor de boedel te verwerven. Dethmers plaatst deze voorwaarde in de sleutel van de redelijke kans van slagen van de schuldsanering, waartoe de voorzienbare inkomsten en noodzakelijke uitgaven in balans moeten zijn en de verzoeker voorts in een stabiele situatie dient te verkeren. ${ }^{\mathrm{I} 20}$ Als echter verwacht wordt dat de verzoeker in de nakoming van zijn verplichtingen zal tekortschieten door omstandigheden die niet aan hem zijn toe te rekenen, is dit volgens een arrest van de Hoge Raad uit 2007 niet voldoende om het verzoek af te wijzen: de afwijzingsgrond is volgens de Hoge Raad gericht op toetsing van de (toekomstige) goede trouw van de schuldenaar (HR I3 april 2007, NJ 2007, 372). Nu de wetgever bij de wijzigingen van 2008 heeft benadrukt dat de toegang dient te worden beperkt voor schuldenaren die 'er niet klaar voor zijn', vraag ik mij af of het arrest zijn betekenis inmiddels niet heeft verloren. Terughoudendheid bij de toelating kan ook voor de schuldenaar van belang zijn, omdat bij het mislukken van de schuldsanering een nieuwe toelating in beginsel gedurende tien jaar niet openstaat (art. 288 lid 2 onder d Fw). ${ }^{\text {I2I }}$

\section{Bevoegdheden van de bewindvoerder; toezicht door de rechter- commissaris; de schuldeisers}

De toepassing van de schuldsaneringsregeling betekent voor de schuldenaar een einde van de directe druk van zijn schuldeisers, bescherming tegen ontruiming van

II8. Nederlandse Vereniging voor Rechtspraak, Advies inzake het voorontwerp Insolventiewet, p. 5 . Daarnaast wordt benadrukt dat de goede trouw-toets van belang is voor het maatschappelijk draagvlak van de regeling.

II9. B. Engberts, 'Het wetsontwerp Wsnp (deel r): De toegang tot de Wsnp en de dwangregeling', Schuldsanering $2007 / 2$, p. I-8, aldaar p. 6 . Engberts voorspelde verder dat de wijzigingen niet zouden leiden tot beheersing van de instroom, een voorspelling die contrasteert met de sterke daling in de aantallen toelatingsbeschikkingen in 2008 (al kunnen daar uiteraard ook andere oorzaken aan ten grondslag liggen).

I20. Dehtmers, Van schuldsanering tot schone lei, p. 35 .

I2I. Van Buchem-Spapens en Pouw, Faillissement, surseance van betaling en schuldsanering, p. I33, achten het evenwel aannemelijk dat het arrest zijn gelding onder het nieuwe recht heeft behouden. 
zijn woning en het afsluiten van nutsvoorzieningen. Van zijn inkomsten wordt een bedrag vrijgelaten waarmee hij geacht wordt zijn noodzakelijke uitgaven te kunnen doen. Ten aanzien van hetgeen buiten de boedel valt is de schuldenaar beschikkingsbevoegd (zij het dat daarmee geen betalingen kunnen worden gedaan aan schuldeisers voor wie de schuldsaneringsregeling werkt, art. $306 \mathrm{Fw}$ ). Hoewel de wet geen bepaling bevat die het de schuldenaar verbiedt om een door hem uitgeoefend beroep of bedrijf voort te zetten, zal dit veelal slechts kunnen geschieden met gebruikmaking van goederen die tot de boedel behoren. Art. 3II FW houdt een regeling dat de schuldenaar met toestemming van de rechter-commissaris gedurende zekere periode bevoegd is de onderneming voort te zetten, en wel: voor rekening van de boedel. In de praktijk wordt van deze mogelijkheid niet veel gebruik gemaakt, met name met het oog op het risico van het ontstaan van nieuwe schulden. ${ }^{\text {I22 }}$

Daartegenover zal de schuldenaar moeten voldoen aan een aantal, hiervoor reeds genoemde verplichtingen (zoveel mogelijk afdragen aan de boedel, verschaffen van relevante inlichtingen, voorkomen van nieuwe schulden, geen schuldeisers benadelen, niet de uitvoering van de regeling belemmeren of frustreren). Door een juiste nakoming van deze verplichtingen kan de omvang van de boedel zo groot mogelijk zijn, waardoor de schuldeisers nog zoveel mogelijk op hun vorderingen kunnen ontvangen. In de praktijk zijn uitdelingen aan schuldeisers overigens, als zij al kunnen plaatsvinden, veelal bescheiden. ${ }^{\text {I23 }}$ Gedurende de schuldsanering heeft de schuldenaar vooral te maken met de bewindvoerder en daarnaast met de rechtercommissaris. Soms spelen ook schuldeisers een rol.

\section{I De bewindvoerder}

Behalve met het beheer en de vereffening van de boedel, is de bewindvoerder belast met het toezicht op de naleving door de schuldenaar van diens verplichtingen uit de schuldsaneringsregeling (art. 316 Fw). ${ }^{124}$ Op zijn beurt staat de bewindvoerder onder toezicht van de rechter-commissaris (art. 3I4 Fw). Anders dan bij faillissement voorziet de wet niet in de mogelijkheid van benoeming van een commissie uit de schuldeisers. Individuele schuldeisers kunnen bij de rechter-commissaris opkomen tegen handelingen van de bewindvoerder of verzoeken om een bevel dat hij een bepaalde handeling zal verrichten of nalaten (art. $317 \mathrm{Fw}$ ).

De bevoegdheden van de bewindvoerder m.b.t. de boedel zijn vergelijkbaar met die van de faillissementscurator (beheer en beschikking, mede omvattende het opzeggen of juist gestanddoen van overeenkomsten, tegeldemaking, het overnemen of aanvangen van procedures voor de boedel, enz.). Wat het verstrekken van inlich-

I22. In de Recofa-richtlijnen (nr. I7) is bepaald dat een onderneming in beginsel niet wordt voortgezet. Voortzetting kan wel worden toegestaan om lopende zaken af te wikkelen of als er een akkoord kan worden aangeboden.

123. Uitdelingen vinden plaats in $76 \%$ van de zaken. zaken. De uitdeling varieert in de meeste gevallen van 1000 tot 5000 euro (in $32,5 \%$ van de zaken) dan wel van 5000 tot 25.000 euro (in $36 \%$ van de zaken). Monitor Wsnp, derde meting, 2007, p. 49.

I24. Het toezicht op de schuldenaar wordt in art. 3I6 Fw vooropgesteld. Gelet op de primaire doelstelling van de wsnp om schuldenaren de mogelijkheid te bieden van een schuldenvrije toekomst, is dat begrijpelijk. 
tingen betreft, bestaat jegens de bewindvoerder een meer algemene verplichting dan voor faillissement voortvloeit uit art. I05 Fw. Verzaakt de schuldenaar deze verplichting, dan kan de bewindvoerder om tussentijdse beëindiging van de schuldsanering verzoeken, indien zulks een duidelijke aanwijzing vormt dat bij de schuldenaar de van hem te vergen medewerking aan een doeltreffende uitvoering van de schuldsaneringsregeling ontbreekt (HR I5 februari 2002, NJ 2002, 259).

Van de bewindvoerder wordt volgens de Recofa-richtlijnen verwacht dat hij in principe binnen twee weken na de toelatingsbeschikking een huisbezoek aflegt bij de schuldenaar. Daarbij dient hij een, vrij uitvoerige, checklist in te vullen, welke door de schuldenaar wordt ondertekend en onder meer als basis kan dienen voor het bepalen van het vrij te laten bedrag. De schuldenaar verklaart door ondertekening ook dat hij door de bewindvoerder is geïnformeerd over zijn verplichtingen en de mogelijke sancties bij verzuim. Het huisbezoek - dat niet als zodanig in de wet is geregeld - wordt door de meeste bewindvoerders van groot belang geacht, vooral om een beter beeld te krijgen 'welk vlees men in de kuip heeft' en voor het verkrijgen van relevante documenten en informatie. ${ }^{\text {I25 }}$

Wel in de wet geregeld is de postblokkade (art. 287 lid 5 Fw): gedurende dertien maanden ontvangt de bewindvoerder alle brieven (en telegrammen) voor de schuldenaar rechtstreeks van de posterijen. De rechter-commissaris kan deze termijn op verzoek van de bewindvoerder wijzigen of, indien de postblokkade reeds is geëindigd, een nieuwe postblokkade instellen. Vóór 2008 gold de postblokkade voor de hele duur van de schuldsanering. ${ }^{\mathrm{I} 26}$ De verkorting in duur is vooral ingegeven door de wens om de werklast voor bewindvoerders te beperken. ${ }^{127}$ Hoewel bewindvoerders de postblokkade erg belangrijk vinden voor een goede taakuitoefening, is men over de werking ervan niet onverdeeld positief. ${ }^{128}$ Zo zou de blokkade makkelijk te omzeilen zijn en zijn er de nodige problemen met het postbedrijf. Waar door de blokkade nuttige gegevens worden verkregen, hebben die het vaakst te maken met nieuwe schulden die de schuldenaar is aangegaan.

De bewindvoerder dient binnen twee maanden na de toelating en vervolgens in beginsel zesmaandelijks verslag te doen van 'de toestand van de boedel', resp. 'de voortgang van de schuldsaneringsregeling' (art. 3i $8 \mathrm{Fw}$ ). Ook voorafgaand aan de verificatievergadering en de beëindiging van de schuldsaneringsregeling dient een verslag te worden uitgebracht. De verslagen, waarvoor modellen zijn ontwikkeld, zijn voor de schuldeisers in te zien. ${ }^{\mathrm{I} 9}$

I25. Monitor Wsnp, vierde meting, 2008, p. 44.

I26. Een postblokkade vormt een ingrijpende inbreuk op de persoonlijke levenssfeer van de schuldenaar. In het Voorontwerp-Insolventiewet (artikelen 2.2.8 lid 4 en 4.2.7a-4.2.8a) is de postblokkade daarom beperkt tot zes maanden. Een langere postblokkade is wel mogelijk, maar vergt - mede om te voldoen aan artikel 8 EVRM - een rechterlijke beslissing (vgl. EHRM 17 oktober 2003, Luordo/Italië). De meeste bewindvoerders achten zes maanden te kort (Monitor Wsnp, vierde meting, 2008, p. 4I) en geven de voorkeur aan dertien maanden.

I27. Kamerstukken II 2004-2005, 29 942, nr. 3, p. I6.

I28. Monitor Wsnp, vierde meting, 2008, p. 40.

I29. Van het verslag ter gelegenheid van het verstrijken van de termijn van de schuldsaneringsregeling (art. 35 Ia Fw) is niet geregeld dat dit ter inzage voor de schuldeisers wordt neergelegd. In de praktijk gebeurt dit wél (Recofa-richtlijnen, nr. 24 onder d). 
De bewindvoerder heeft uiteraard recht op vergoeding voor zijn werkzaamheden. Behalve salaris uit de boedel kan de bewindvoerder ook subsidie ontvangen van de Raad voor rechtsbijstand te 's-Hertogenbosch. In 2009 zal de subsidie nog slechts worden betaald in de vorm van een voorschot, dat moet worden terugbetaald in gevallen dat de omvang van de boedel voldoende is om de gehele vergoeding te voldoen. Daardoor wordt naar verwachting zowel een beperking van kosten bereikt als een versterking van het 'stok achter de deur'-effect.

\subsection{De rechter-commissaris}

Aan de schuldenaar wordt de vrije beschikking over zijn vermogen ontnomen en aan de schuldeisers hun individuele verhaalsmogelijkheden. In plaats daarvan wordt de bewindvoerder belast voor het beheer en de vereffening van de boedel. Zowel bij de schuldenaar als bij de schuldeisers ligt een zeker wantrouwen tegen de bewindvoerder voor de hand, niet in het minst omdat een deel - of zelfs het geheel - van de boedel opgaat aan diens salaris. Dat vraagt om toezicht.

Het toezicht op de bewindvoerder is opgedragen aan de in de toelatingsbeschikking benoemde rechter-commissaris (art. 3I4 Fw). De aantallen zijn groot: volgens Dethmers beheert elke voltijds werkzame rechter-commissaris gemiddeld zo'n 750 schuldsaneringen en 500 faillissementen. Daarbij schat hij de ondersteuning van de rechter-commissaris op gemiddeld 2 fte juridisch gekwalificeerd personeel en $3 \mathrm{fte}$ administratief personeel. ${ }^{\mathrm{I} O} \mathrm{~T}$ Terecht wijst Dethmers erop dat de toezichthouder bij deze aantallen zijn band met individuele zaken verliest. Enige jaren geleden heeft de Tweede Kamer in een motie vastgesteld dat er 'regelmatig' klachten zijn over curatoren, bewindvoerders en rechters-commissarissen en dat in verband daarmee het toezicht door rechters-commissarissen zou moeten worden verbeterd. ${ }^{13 \mathrm{I}}$ De toenmalige minister van Justitie reageerde aan de hand van diverse reacties van in de praktijk betrokken organisaties (advocatuur, rechters-commissarissen, Raad voor rechtsbijstand). ${ }^{132}$ Hoewel de meeste betrokkenen zeker verbeteringen mogelijk achtten, beoordeelde men het bestaande toezicht niet als onder de maat. De minister stelde vast dat de werkdruk bij de gerechten weliswaar hoog was, maar dat er geen aanwijzingen zijn dat het toezicht daadwerkelijk tekortschiet. Verder wees hij erop dat de grote aantallen een verschuiving vergen van een zaaksgerichte behandeling naar een meer sytematisch georganiseerde aanpak.

Dat laatste is de afgelopen jaren ook daadwerkelijk geschied. De richtlijnen voor schuldsaneringen, ontwikkeld door Recofa in overleg met de Raad voor rechtsbijstand te 's-Hertogenbosch, bevatten op tal van punten uitgewerkt beleid dat door rechtbanken en rechters-commissarissen wordt toegepast. De aanwezigheid van een vast beleid maakt het ook mogelijk dat veel werk, zoals het lezen en beoordelen van verslagen en het controleren van voorstellen voor het vrij te laten bedrag, wordt gedelegeerd aan het

I30. Dehtmers, Van schuldsanering tot schone lei, p. 67.

I3I. Motie Weekers/De Vries/Douma, Kamerstukken II 2003-2004, 27 244, nr. 20.

I32. Brief van I3 september 2005, Kamerstukken II 2005-2006, 27 244, nr. 24. 
ondersteunend apparaat. ${ }^{\mathrm{I} 33}$ Het toezicht van de rechter-commissaris krijgt vooral gestalte in de vaststelling van het beleid en de toetsing van de verslagen van bewindvoerders aan dat beleid. Daarbij wordt niet alleen de bewindvoerder gecontroleerd, maar (vooral) ook of de schuldenaar aan zijn verplichtingen voldoet en, zo nee, of de schuldenaar daarop wordt gecorrigeerd. ${ }^{134}$ Behalve uit verslagen van de bewindvoerder kan de rechter-commissaris informatie verkrijgen door een verhoor van de schuldenaar en zijn in (enige) gemeenschap gehuwde echtgenoot of geregistreerde partner (art. I05 jo. $327 \mathrm{Fw}$ ). Voorts kunnen getuigen worden gehoord of een onderzoek door deskundigen worden bevolen (art. 66 jo. 3 I4 lid2 Fw).

Met welke middelen oefent de rechter-commissaris zijn invloed als toezichthouder uit? In de bekende formulering uit de toelichting bij de Faillissementswet: 'De middelen van invloed, die hem ten dienste staan, zijn raadgevingen, opmerkingen, berispingen, des noodig toepassing van art. 73' (d.w.z. voordracht voor ontslag). ${ }^{\text {I35 }}$ Klachten van schuldeisers bieden de rechter-commissaris een concrete gelegenheid zich met het optreden van de bewindvoerder bezig te houden (en hem zo nodig te berispen). Duidelijke invloed gaat voorts ook uit van beslissingen op verzoeken van schuldeisers die tegen de bewindvoerder opkomen (art. 317 Fw). Van meer preventief toezicht is sprake waar de wet voor bepaalde handelingen van de bewindvoerder goedkeuring, machtiging of toestemming van de rechter-commissaris voorschrijft. ${ }^{136}$ Ook in de salarissfeer heeft de rechter-commissaris middelen voor beïnvloeding (art. $320 \mathrm{Fw}$ ).

Van groot belang is dat de Raad voor rechtsbijstand 's-Hertogenbosch, die subsidies aan bewindvoerders verstrekt, een vrij uitvoerige regeling hanteert met betrekking tot de kwaliteit, continuïteit, onafhankelijkheid en organisatie van bewindvoerderskantoren. Om als bewindvoerder te kunnen worden benoemd, is voldoening aan deze regeling (behalve voor advocaten) vereist (Recofa-richtlijnen, nr. 9a). Op deze grondslag is de afgelopen jaren door de Raad voor rechtsbijstand veel bereikt op het punt van professionalisering van bewindvoerders, onder meer door het houden van 'audits'.

In de reeds genoemde brief van de minister van Justitie van I3 april 2005 is op grond van de reacties van vele betrokkenen vermeld dat het bestaande toezicht door de rechter-commissaris (in faillissementen, surseances en schuldsaneringen) weliswaar niet daadwerkelijk tekortschiet, maar dat wel verbeteringen mogelijk zijn. Genoemd werden maatregelen als betere opleiding, een ander benoemingenbeleid

I33. Volgens Jongeneel, 'De inspanningstermijn na insolventie', p. I6, wordt het leeuwendeel van het bureau-werk in de schuldsanering gedaan door secretarissen en administratief-juridisch medewerkers.

I34. Dethmers, Van schuldsanering tot schone lei, p. 67. Jongeneel, 'De inspanningstermijn na insolventie', p. 16 , vermeldt dat de rechter-commissaris vervolgens in een aanzienlijk aantal zaken zelf corrigerend optreedt jegens de schuldenaar in een aangetekende brief of door middel van een verhoor van de schuldenaar.

I35. Van der Feltz II, p. 2.

136. Zo is bijvoorbeeld toestemming nodig voor het geval de bewindvoerder goederen niet onderhands maar in het openbaar wil verkopen (art. 347 lid 2 Fw). In de praktijk wordt ook voor onderhandse verkoop een verzoek om toestemming verlangd, aan de hande van een model als de activa meer dan $€ 2000$ belopen (Recofa-richtlijnen, nr. 2I onder c; het model is afgedrukt in het Jaarboek schuldsanering 2006, p. I46). 
en meer samenwerking tussen de gerechten. Recofa bepleitte voorts meer transparantie, door publicatie van relevante stukken op internet, waardoor schuldeisers zich meer betrokken kunnen voelen bij het beheer en de afwikkeling van de boedel en 'het toezicht als geheel kan toenemen' (p. II). De minister liet zich zelf voorzichtig positief uit over de gesuggereerde maatregelen, onder meer ook over de gedachte aan meer toezicht door schuldeisers (p. I5). Ook Dethmers is voorstander van meer directe verslaglegging aan schuldeisers door moderne communicatiemiddelen, waardoor de taak van de rechter-commissaris zich verplaatst naar het beslissen op geschillen over het beheer tussen schuldeisers en de bewindvoerder. ${ }^{137}$

Tot slot vermeld ik dat vanuit de rechterlijke macht verschillende malen aandacht is gevraagd voor het terugdringen van rechterlijke bemoeienis met insolventietoezicht, te weten door Verschoof, ${ }^{\mathrm{I}}{ }^{8}$ Van der Weide ${ }^{\mathrm{I} 39}$ en door Van Delden en Bauw. ${ }^{\mathrm{I} 40}$

\subsection{De schuldeisers}

In het oog springt dat de schuldeisers geen rol spelen bij de beoordeling van het verzoek tot toelating tot de wsnp, tegen die toelating geen rechtsmiddelen kunnen instellen (art. 292 lid $2 \mathrm{Fw}$ ), ook niet via de omweg van een verzoek om tussentijdse beëindiging, indien de redengevende omstandigheden bij de toelating reeds aan de rechter bekend waren (art. 350 lid 3 onder f Fw, alsmede HR 5 september 2008, LJN: $\mathrm{BD}_{3425}$ ). ${ }^{\mathrm{I}}{ }^{\mathrm{I}}$ Wel kunnen zij opkomen bij de behandeling van de beëindiging van de regeling, die wordt aangekondigd in de Staatscourant (art. 352 lid 3 en 353 lid 2 Fw) of zelf een verzoek doen tot tussentijdse beëindiging (art. 350 lid I Fw). Daarbij zal het met name gaan om de vraag of er nieuwe omstandigheden bekend zijn geworden die - indien eerder bekend - aanleiding zouden hebben gevormd de schuldenaar niet toe te laten (art. 350 lid 3 onder $\mathrm{f} \mathrm{Fw}$ ), dan wel of de schuldenaar in relevante mate en toerekenbaar is tekortgeschoten in de nakoming van zijn verplichtingen uit de schuldsaneringsregeling (art. 354 Fw).

I37. Dethmers, Van schuldsanering tot schone lei, p. 7I.

I38. R.J. Verschoof, 'Een grotere stok achter de half gesloten deur', Tijdschrift voor Insolventierecht 2004, p. 45-48, aldaar p. 48. Volgens Verschoof, die lid was van de Commissie Schone Lei II, zou heel wel gewerkt kunnen worden met gedifferentieerd toezicht, waarbij de rechter alleen gericht wordt ingeschakeld bij liquidatie, aflossingscapaciteit, uitdeling en schone lei.

I39. C.J.G.M. van der Weide, 'Haal de WSNP weg bij de rechtbank', Tijdschrift voor Insolventierecht 2004, p. I29-I3I. Van der Weide beveelt een opzet aan waarbij de gemeente een veel zwaardere rol krijgt bij schuldsaneringen, met slechts (niet-preventieve) bestuursrechtelijke rechtsbescherming.

I40. A.H. van Delden en E. Bauw, 'Toezicht in faillissementen, een rechterlijke taak?', Tijdschrift voor Insolventierecht 2004, p. 233-236. Ook zij bepleiten - geven althans in overweging - om de taak van de rechter te beperken tot de beslechting van geschillen en het toezicht elders te beleggen, waarbij zij denken aan het versterken van de controlemogelijkheden voor belanghebbenden, met name schuldeisers. Van Delden en Bauw stellen met enige nadruk de vraag of de rol van de rechter-commissaris als toezichthouder zich wel verdraagt met die van 'sparring partner' of klankbord voor de curator. Hoewel zij zich primair richten op faillissementen, geldt hetzelfde voor schuldsaneringen (p. 233).

I4I. Vanuit oogpunt van hoor en wederhoor is dit natuurlijk enigszins merkwaardig (aldus ook Dethmers, 'De schuldsaneringsregeling processueel benaderd', p. 92). Schuldeisers tegen wie voorlopige voorzieningen worden gevraag op grond van art. 287 lid 4 of $287 \mathrm{~b} \mathrm{Fw}$, worden uiteraard wél opgeroepen. Hetzelfde geldt voor schuldeisers tegen wie een bevel wordt verzocht tot instemming met een voor de indiening van het verzoek aangeboden schuldregeling (art. 287a Fw). 
In veel (andere) opzichten verschilt de positie van schuldeisers in de schuldsaneringsregeling niet (meer) sterk van die in faillissement. Zo kunnen zij evenmin als de schuldenaar zelf opkomen tegen beslissingen omtrent het vrij te laten bedrag (art. 3 I5 lid 2, vgl. art. 67 lid IFw). Te denken valt verder aan de afkoelingsperiode (art. 63 jo. $313 \mathrm{Fw}$ ) en de voortgezette verstrekking van nutsvoorzieningen (art. $304 \mathrm{Fw}$ ). Anders evenwel dan in faillissement is degene die woonruimte aan de schuldenaar verhuurt, beperkt in de mogelijkheid de huur op te zeggen of te ontbinden en om uitvoering te geven aan een reeds verkregen ontruimingsvonnis (art. $305 \mathrm{Fw}$, vgl. art. $39 \mathrm{Fw}$ ). Wil een schuldeiser zijn vordering op de schuldenaar realiseren door verrekening met een schuld, dan dienen schuld en vordering te zijn ontstaan vóór de uitspraak tot toepassing van de schuldsaneringsregeling, hetgeen beperkter is dan in faillissement (art. 307 lid I, vgl. art. 53 lid I Fw). Vergelijkbaar zijn de regelingen op het punt van kennisneming van verslagen, de mogelijkheid om op te komen tegen handelen of nalaten van de bewindvoerder, alsmede de indiening en verificatie van vorderingen. ${ }^{\mathrm{I} 2}$ Zoals reeds genoemd kan in de schuldsanering, anders dan in faillissement, geen commissie uit de schuldeisers worden benoemd.

Een belangrijk verschil met faillissement is gelegen in de onderlinge verhouding tussen concurrente en preferente schuldeisers. Komt het tot uitdelingen, dan geschieden deze zowel aan concurrente als aan preferente schuldeisers, met dien verstande dat laatstgenoemde schuldeisers een twee keer zo groot percentage op hun vorderingen ontvangen (art. 349 lid $2 \mathrm{Fw}$ ). ${ }^{\mathrm{I}} 43$ De onderlinge rangorde van preferente vorderingen is hierbij niet van invloed. Vorderingen die op een bepaald goed bevoorrecht zijn, worden slechts als preferent beschouwd voor zover zij op de opbrengst van dat goed batig gerangschikt kunnen worden (art. 349 lid 3 Fw). De 2:I-regel is ontleend aan de Commissie Mijnssen, onder weglating van de bijzonderheid dat voor preferente schuldeisers in schuldsanering ten minste beschikbaar zou moeten zijn wat zij anders in faillissement zouden ontvangen. ${ }^{\mathrm{I}}{ }^{4}$ De beperking van rechten van bevoorrechte schuldeisers strekt ertoe om in elk geval enige uitkering voor concurrente schuldeisers zeker te stellen en tegelijk te voorkomen dat preferente schuldeisers medewerking zouden gaan weigeren aan minnelijke regelingen waarbij ook concurrente schuldeisers een uitkering ontvangen. In die zin past de regel dus in de 'stok achter de deur'-benadering. Daar staat echter tegenover dat, zolang dezelfde regel niet geldt bij (cumulatieve) beslaglegging, een beslaglegger met een concurrente vordering geneigd zou kunnen zijn om het failissement van de schuldenaar aan te vragen. Gevolg daarvan zal immers veelal zijn dat de schuldenaar toelating tot de wnsp verzoekt, met voor de schuldeiser het gunstige gevolg van de 2:I-regel. Overigens wordt ook bij schuldregelingen in het minnelijk traject uitge-

I42. Sinds 2008 voorziet art. $328 \mathrm{a} \mathrm{Fw}$ in de mogelijkheid dat de verificatievergadering 'slechts proforma' zal plaatsvinden, d.w.z. dat alle vorderingen zullen gelden als geverifieerd zoals door de bewindvoerder in daartoe opgestelde lijsten van vorderingen aangegeven, tenzij een schuldeiser laat weten dat er wèl een vergadering dient plaats te vinden.

I43. Deze 2:I-regel is alleen vastgelegd voor uitdelingen en geldt dus niet voor verhaal door separatisten.

I44. Rapport Commissie Mijnssen, p. 244-245. Deze regel is niet overgenomen omdat zij noopt tot ingewikkelde vaststellingen en er voorts in veel gevallen voor concurrente schuldeisers niets zou overschieten (Kamerstukken II I992/93, 22 969, nr. 3, p. I9). 
gaan van de 2:I-regel. ${ }^{\mathrm{I}}{ }^{5} \mathrm{Er}$ valt veel voor te zeggen om de regel algemeen te maken, zodat zij ook zal gelden bij samenlopende executiemaatregelen van individuele schuldeisers en in faillissement. ${ }^{\mathrm{I}}{ }^{6}$

De beperking van de rechten van preferente schuldeisers werkt door bij de regeling van het akkoord. Ook preferente schuldeisers kunnen worden gebonden aan een door de schuldenaar aangeboden akkoord en zij mogen derhalve meestemmen. Vanzelfspekend zal de 2:I-regel voor uitdelingen uitstralen naar het akkoord, in die zin dat een te grote afwijking van de wettelijke uitdelingsregels de aanvaarding van het akkoord zal bemoeilijken. In de wet is gekozen voor een stemming in afzonderlijke groepen, waarbij voor aanvaarding van het aangeboden akkoord zowel in de groep van preferente schuldeisers als in de groep van concurrente schuldeisers een bepaalde meerderheid moet worden behaald (art. $332 \mathrm{Fw}$ ). Hoewel het groepensysteem op zichzelf overzichtelijk is, bestaat er principieel gezien geen noodzaak om de preferente schuldeisers als groep een blokkerende stem over het akkoord toe te kennen. ${ }^{47}$

\section{$8 \quad$ De schone lei}

De schone lei die de schuldenaar kan verkrijgen, houdt in dat de vorderingen waarvoor de schuldsaneringsregeling werkt, voor zover zij bij beëindiging van de schuldsanering niet zijn voldaan, van hun afdwingbaarheid worden ontdaan en derhalve worden omgezet in natuurlijke verbintenissen (art. $358 \mathrm{Fw}$ ). Daarbij is niet van belang of de schuldeiser in de procedure is opgekomen en of zijn vordering al dan niet is geverifieerd. Niet-afdwingbaarheid staat ook in de weg aan verrekening (art. 6:127 lid 2 BW). ${ }^{\mathrm{I} 48}$ In de schone lei is de kern van de schuldsaneringsregeling gelegen: de schuldenaar maakt een fresh start.

De wetgever heeft mede gekozen voor de niet-afdwingbaarheid i.p.v. verval van restvorderingen om te voorkomen dat ook derden, zoals borgen en andere mede-

I45. Art. 7.4 Gedragscode schuldregeling. Een wetswijziging is in voorbereiding om ook socialezekerheidsinstellingen (UWV, SVB) te kunnen laten meewerken aan schuldregelingen, mits zij daarbij uitgekeerd zullen krijgen op basis van de 2:I-regel (daartoe worden hun vorderingen voorzien van een preferentie).

I46. Eén van de redenen voor de in 2008 aangebrachte wijziging dat bij overlijden van de schuldenaar in de schuldsaneringsregeling de afwikkeling plaatsvindt door de wsnp-bewindvoerder en niet door een daartoe benoemde vereffenaar van de nalatenschap, is geweest dat daarmee wordt voorkomen dat de onderlinge verhoudingen tussen de schuldeisers gewijzigd wordt.

I47. In het Voorontwerp-Insolventiewet, dat eveneens uitgaat van de 2:I-regel, wordt de groepenbenadering verlaten ten gunste van een stemming waarbij aan de stemmen van preferente schuldeisers slechts een dubbel gewicht toekomt.

I48. De fiscus acht zich wél gerechtigd tot verrekening van na het einde van de schuldsanering vastgestelde belastingteruggaven die betrekking hebben op de periode vóór de toelating tot de wsnp, met vorderingen op de schuldenaar die inmiddels niet meer afdwingbaar zijn (Leidraad Invordering 2008, artikel 73.2.2). 
schuldenaren daarvan zouden profiteren. ${ }^{49}$ Voor wat echtgenoten betreft, is het daarom van belang dat zij in voorkomende gevallen ook zelf de schuldsanering doorlopen. Wat borgen betreft, verdient aandacht dat de schuldsaneringsregeling ook werkt t.a.v. regresvorderingen op de schuldenaar, ontstaan na de toelating, en dat deze derhalve ook onder de schone lei vallen (art. 299 lid I onder e Fw). ${ }^{150}$

Alvorens in te gaan op de uitzonderingen op de schone lei, noem ik eerst een uitbreiding: onder de schone lei vallen ook restvorderingen uit boedelschulden, ontstaan uit een faillissement dat op grond van artikel ${ }_{15} \mathrm{~b}$ Fw is omgezet in een schuldsanering (art. 358 lid 3 Fw). De hoofdregel is dus dat de schone lei geen boedelschulden omvat. Met dit bijzondere geval heeft de wetgever vooral gedacht aan ex-ondernemers die niet onmiddellijk in de schuldsanering terecht kunnen, omdat zij er niet aan ontkomen nog enige nieuwe schulden te maken (bv wegens ontslag van werknemers, korte voortzetting van de onderneming of lopende verplichtingen), hetgeen tot tussentijdse beëindiging van de schuldsanering zou leiden. Vreemd is wel dat wat hier geldt voor de omweg van faillissement, niet ook zou kunnen gelden voor vergelijkbare boedelschulden die in de schuldsanering ontstaan. ${ }^{\mathrm{I} I}$

Dan kom ik op de uitzonderingen op de schone lei. Een eerste uitzondering betreft de vordering waarvoor een hypotheek tot zekerheid strekt, gevestigd op de woning van de schuldenaar, in het geval dat de rechtbank toestemming heeft gegeven de hypotheekrentetermijnen tijdens de schuldsanering door te betalen (art. 358 lid 5 Fw). Deze uitzondering is in het belang van de schuldenaar, omdat de hypotheeknemer anders zeker tot uitwinning zou overgaan. Uit de bepaling komt naar voren dat in het algemeen de schone lei ook vorderingen betreft die met zakelijke zekerheden zijn versterkt. ${ }^{152}$

Een tweede uitzondering vormen vorderingen uit studieschulden als bedoeld in art. 299a Fw, doordat de ten aanzien van deze vorderingen de schuldsaneringsregeling niet werkt. In plaats daarvan is voorzien in (verder) uitstel van de aflossing, zonder rentegroei.

Een derde uitzondering op de schone lei is te vinden in het erfrecht: de artikelen 4:I3 lid 5 en 4:8I lid 6 BW. Het gaat om de vordering die het kind van de erflater heeft verkregen op de langstlevende echtgenoot die de nalatenschap heeft verkregen, hetzij uit hoofde van de wettelijke verdeling, hetzij uit hoofde van een beroep op zijn

I49. Kamerstukken II 1992/93, 22 969, nr. 3, p. 20-22. Algeheel verval van restvorderingen zou ook verder gaan dan nodig, met als gevolg dat nadien gedane vrijwillige betalingen steeds als onverschuldigd zouden moeten gelden (en bijvoorbeeld een schenking zouden opleveren). Voorts sluit deze benadering aan bij de rechtstoestand zoals die geldt na voltooiing van een verjaring of door voldoening aan een akkoord.

150. Niet duidelijk is hoe het staat met regresvorderingen die pas ontstaan nadat de schuldsanering is beëindigd. Louter op grond van de formulering van de artikelen 299 en 358 zou men vermoeden dat zij niet onder de schone lei vallen. Op grond van de strekking van de schone lei neem ik echter aan dat ook regresvorderingen die pas later ontstaan niet tegen de schuldenaar kunnen worden afgedwongen.

I5I. Het gerechtshof 's-Gravenhage heeft de regeling inmiddels bij arrest van 3 juni 2008 (LJN: $\mathrm{BD}_{3267)}$ een ruimere ('redelijke') toepassing gegeven door de schone lei ook op vergelijkbare boedelschulden uit de schuldsanering van toepassing te verklaren.

I52. Hetzelfde doet zich voor bij verjaring, zij het dat de wetgever daarvoor een wettelijke bepaling nodig heeft geacht: artikel 3:323 lid I BW. 
legitieme portie. In beide gevallen gaat het om een langdurig (in beginsel levenslang) niet-opeisbare vordering, die als gevolg van toelating van de langstlevende echtgenoot tot de wnsp opeisbaar is geworden. Voor zover de vordering in het kader van de schuldsanering niet is voldaan, wordt zij na afloop wederom niet-opeisbaar. De wetgever heeft gemeend dat de schuldenaar er geen werkelijk belang bij heeft dat deze vorderingen onder de schone lei vallen, aangezien zij uiteindelijk slechts ten laste van zijn nalatenschap komen.

De belangrijkste uitzonderingen op de schone lei zijn opgenomen in art. 358 lid 4 Fw: vorderingen die voortvloeien uit een in kracht van gewijsde gegane strafrechtelijke veroordeling tot betaling van een geldboete, van een geldbedrag tot ontneming van wederrechtelijk verkregen voordeel, van een geldbedrag ten behoeve van het slachtoffer of van een schadevergoeding aan een benadeelde partij. In de toelichting wordt erop gewezen dat als deze schulden onder de schone lei zouden vallen, de handhaving van het strafrecht in het geding is en rechtsongelijkheid ontstaat ten opzichte van diegenen die hun boetes wel betalen. De schuldsanering zou dan een middel zijn om onder een boete uit te komen, hetgeen vooral bij misdrijven maatschappelijk ongewenst werd geacht. ${ }^{\mathrm{I} 53}$ In het verlengde van deze uitzondering zijn ook door de civiele rechter toegewezen schadevergoedingen uitgezonderd, indien de strafrechter eerder heeft geoordeeld dat deze zich niet leent voor behandeling in het strafproces. Andere vergoedingsvorderingen blijven wèl onder de schone lei vallen, omdat deze groep dermate ruim is dat de wetgever het niet mogelijk achtte een zinvol onderscheid te maken. Men kan zich afvragen hoe overtuigend deze argumentatie is. Zo zou in elk geval een uitzondering voor letselschadevorderingen mijns inziens op zijn plaats zijn geweest. Met de uitbreiding van het aantal uitzonderingen op de schone lei is de schone lei vanaf 2008 minder 'schoon' dan voorheen. Het Nederlandse stelsel komt daarmee meer in lijn te liggen met hetgeen geldt in de ons omringende landen en de Verenigde Staten. ${ }^{\text {I54 }}$

Sluitstuk op de bescherming van schuldeisers tegen de schuldenaar vormt de mogelijkheid om de rechter te verzoeken te bepalen dat artikel 358 lid I Fw (de nietafdwingbaarheid van restvorderingen) verder geen toepassing vindt. Deze mogelijkheid bestaat ingevolge artikel $358 \mathrm{a}$ Fw slechts indien na beëindiging van de schuldsanering blijkt dat zich voordien feiten of omstandigheden hebben voorgedaan die grond zouden hebben opgeleverd voor tussentijdse beëindiging van de schuldsanering wegens (pogingen tot) benadeling van schuldeisers. De beperking tot deze feiten impliceert dat de schuldenaar niet hoeft te vrezen dat zijn financiële lotgevallen na afloop van de schuldsanering nog aanleiding kunnen geven tot verlies van de schone lei. Dat lijkt mij in het licht van de fresh start-gedachte juist: de schuldenaar dient met zijn schone lei maatschappelijk weer onbelemmerd te kunnen functioneren, zonder dat vanachter de schone lei nog latente verplichtingen kunnen opduiken.

I53. Kamerstukken II 2004-2005, 29 942, nr. 3, p. 38. De uitzondering voor strafrechtelijke vorderingen werd in het parlement volledig gesteund, doch stuit daarbuiten bij op veel kritiek (omdat de overheid zichzelf zou bevoordelen). Zie bijvoorbeeld S.C.J.J. Kortmann, 'Vergroot de kans van slagen van het minnelijk traject', in: Tijdschrift voor Insolventierecht 2007, p. 38-39.

154. Aldus Noordam, Schuldsanering en goede trouw, p. 612, waar men een overzicht aantreft van in andere landen bestaande uitzonderingen op de schone lei. 
Voor de mogelijkheid tot het ontnemen van de schone lei is geen bijzondere termijn voorgeschreven. Dethmers meent dat de 'gewone' verjaringstermijn van twintig jaar (art. 3:306 BW) van toepassing is, doch meent dat een termijn van drie of vijf jaar meer in de rede zou liggen. ${ }^{155}$ Gedacht zou ook kunnen worden aan het bijzondere rechtsmiddel van herroeping (art. $390 \mathrm{Rv}$ ), waar de wet een termijn stelt van drie maanden nadat de verzoeker bekend is geworden met de grond voor herroeping. In het Voorontwerp-Insolventiewet is voor de min of meer vergelijkbare regeling van vernieting door de rechter van een akkoord buiten insolventie een termijn opgenomen van drie jaar vanaf het tijdstip waarop de homologatie onherroepelijk is geworden (art. 7.I.3o lid 2 Voorontwerp).

\section{Advisering Commissie insolventierecht}

Met het Voorontwerp-Insolventiewet uit 2007 ligt een uitgewerkt voorstel tot herziening van het insolventierecht ter tafel. De minister van Justitie heeft belanghebbenden en belangstellenden uitgenodigd op het Voorontwerp te reageren. Aan de hand van de ontvangen reacties zal de regering moeten besluiten hoe zij verder wil met het insolventierecht. Indien wordt besloten tot vernieuwing van het insolventierecht op de grondslag van het Voorontwerp, kan de schuldsaneringsregeling in haar huidige vorm moeilijk voortbestaan. Een korte behandeling van hetgeen het Voorontwerp inhoudt voor natuurlijke personen, kan daarom in dit preadvies niet gemist worden.

Het Voorontwerp houdt een unitaire insolventieprocedure in. In plaats van de huidige regelingen voor faillissement, surseance van betaling en schuldsanering natuurlijke personen is gekozen voor één, zoveel mogelijk geïntegreerde, regeling. Aan het afzonderlijk bestaansrecht van de surseance wordt al decennialang getwijfeld. Het integreren van de schuldsanering betekent wetssystematisch een grote verbetering, omdat een einde komt aan grotendeels - maar niet volledig - parallelle regelingen voor tal van onderwerpen en aan de vele kruisverwijzingen die de leesbaarheid van de schuldsaneringsregeling thans bemoeilijken. ${ }^{156}$ In art. I.I.2 van het Voorontwerp is een doelstelling geformuleerd voor de geïntegreerde procedure. Deze is in paragraaf 2 aangehaald. Hoewel de sanering van schulden hier uitdrukkelijk genoemd wordt, heeft het vooropstellen van de belangen van schuldeisers, ook in de toelichting, geleid tot kritiek dat het Voorontwerp het belang van de fresh start-gedachte miskent. ${ }^{157}$ En inderdaad is het beter om ten aanzien van natuurlijke personen in problematische schuldsituaties de indruk te vermijden dat de belangen van de schuldeisers vooropstaan.

De toelichting bij het Voorontwerp stelt vast dat het minnelijk traject in de afgelopen jaren in veel gevallen niet tot zijn recht is gekomen (p. 156). Dat is, gelet op de

I55. Dethmers, 'De schuldsaneringsregeling processueel beschouwd', p. 94. Dethmers verwijst daarbij naar art. 3:52 BW (verjaring bij beroep op nietigheden) en art. 3:310 BW (verjaring van vorderingen tot schadevergoeding).

I56. Voor 2008 verschafte het saneringsplan de regeling een duidelijk afwijkend profiel. Het saneringsplan is echter nooit aangeslagen en om die reden is het in 2008 geschrapt.

157. Huls, 'Het Kortmann-uniform past de schuldsanering niet', p. 274. 
bevindingen van de evaluatie door het WODC en de teleurstellende slagingspercentages van het minnelijk traject, geen wilde conclusie. Van de regeling van art. 287a (het 'dwangakkoord', opgelegd ter gelegenheid van de behandeling van het wsnpverzoek) moet in het licht van het Payroll-arrest nog maar worden afgewacht of het zal leiden tot een substantiële toename van minnelijke regelingen. ${ }^{158}$ Daarnaast wordt volgens de toelichting vaak te lang gewacht met inschakeling van schuldhulpverlening, waardoor een wsnp-verzoek al snel onvermijdelijk is om schuldeisers op afstand te houden. ${ }^{159}$

Bij de toepassing van de schuldsaneringsregeling bestaat volgens de toelichting onduidelijkheid over de verantwoordelijkheden van de bewindvoerder en wordt een voordien toegepast budgetbeheer vaak niet gecontinueerd. De uitvoering van de schuldsaneringsregeling vergt volgens de toelichting te veel, in de vorm van regelmatige bemoeienissen van de bewindvoerder en langdurig toezicht door de rechtercommissaris. Of de beoogde strengere toelating zal blijken te werken is onzeker, ${ }^{\mathrm{I} 6 \mathrm{o}}$ en als dat al het geval is, dreigt een groeiende groep schuldenaren tussen wal en schip te vallen.

Een aantal van de voorstellen in het Voorontwerp is gericht op daadwerkelijke versterking van het minnelijk traject.

In de eerste plaats dient de schuldenaar zich ter verkrijging van een schone lei gedurende in beginsel drie jaren in voldoende mate in te spannen om zijn schulden te voldoen. Daarbij wordt ook volledig rekening gehouden met de duur van het minnelijk traject, mits uitgevoerd onder begeleiding van een 'stille bewindvoerder' (art. 6.4.4 lid I). Als het minnelijk traject behoorlijk functioneert, is er inderdaad geen enkele reden waarom de inspanningen van de schuldenaar in die fase niet zouden mogen meewegen voor de schone lei. Het wetttelijk traject kan daardoor sterk worden bekort.

In de tweede plaats is voorzien in de mogelijkheid dat door de rechter een stille bewindvoerder wordt benoemd. Zijn bevoegdheden zijn beperkt: het gaat er primair om dat vaststaat vanaf welk moment de schuldenaar in het minnelijk traject zodanig wordt begeleid dat daarmee rekening mag worden gehouden bij de vraag of een schone lei kan worden verleend. Als de certificering van schuldhulpverleners van de grond komt, verliest dit aspect m.i. enigszins aan betekenis. De stille bewindvoerder speelt daarnaast ook een rol bij het verkrijgen van voorlopige voorzieningen ter ondersteuning van het minnelijk traject (art. 7.2.3), waaronder het verkrijgen van opheffing van een gelegd beslag. Er is in de Commissie insolventierecht veel gesproken over verdergaande mogelijkheden van een moratorium, maar de overheersende mening was dat een vergaande inperking van bevoegdheden van schuldeisers moeilijk te verantwoorden valt zonder de waarborgen die een insolventie biedt in de vorm

I58. Gelet op de opmerking van Van Buchem-Spapens en Pouw, Faillissement, surseance van betaling en schuldsanering, p. I30, dat de wetgever in het Payroll-arrest geen aanleiding heeft gezien het voorgestelde art. $287 \mathrm{a}$ aan te scherpen, verwachten zij kennelijk dat de Hoge Raad aan zijn strenge lijn zal vasthouden. Dat is niet zonder betekenis, nu eerstgenoemde auteur zelf deel uitmaakt van de Hoge Raad.

I59. Dit gegeven is mij onlangs nog bevestigd door een deurwaarder, die zich beklaagde over voorlopige voorzieningen ex art. $287 \mathrm{~b}$ die vaak op het allerlaatste moment worden aangevraagd.

I6o. Inmiddels tekent zich een sterke daling af in de toelatingen. 
van onttrekking van de beschikking over het vermogen aan de schuldenaar en rechterlijk toezicht.

In de derde plaats bevat het Voorontwerp een regeling voor een akkoord buiten insolventie (afdeling 7.I), die in de plaats zou kunnen komen van de op misbruik van recht gestoelde regeling voor een bevel tot medewerking aan een in het minnelijk traject aangeboden schuldregeling (art. 287a Fw). De regeling lijkt op die van het akkoord in faillissement, surseance of schuldsanering, met als kenmerkende verschil dat het akkoord slechts werkt tegen de schuldeisers die bij de aanbieding van het akkoord zijn genoemd of daaraan voorafgaand aan de behandeling zijn toegevoegd. ${ }^{\mathrm{I}}{ }_{\mathrm{I}}$ Doordat schuldeisers over het akkoord stemmen, kunnen dwarsliggende schuldeisers worden gebonden, ook als geen sprake is van misbruik van recht. Daarbij kan voorts een tegenstem die aanneming van het akkoord heeft verhinderd, door de rechter-commissaris worden gepasseerd indien de schuldeiser in redelijkheid niet tot zijn stemgedrag had kunnen komen, waarbij in het bijzonder van belang is welk percentage op de vordering zou worden ontvangen als het tot een insolventie zou komen. Met andere woorden: het uitgangspunt van het Payrollarrest (HR I2 augustus 2005, NJ 2006, 230) dat elke schuldeiser het in beginsel mag laten aankomen op een insolventie, wordt verlaten. Uiteraard bestaat het risico dat de schuldenaar selectief is bij het opstellen van de lijst van schuldeisers, om zo bijvoorbeeld de kansen op aanvaarding te vergroten. Dit risico wordt bestreden doordat de stille bewindvoerder over de betrouwbaarheid van de lijst dient te rapporteren en doordat het akkoord achteraf vernietigd kan worden op verzoek van iedere in het akkoord betrokken schuldeiser, indien blijkt dat verzuimd is een of meer schuldeisers in het akkoord te betrekken (art. 7.I.30). Het akkoord buiten insolventie wordt gepubliceerd in het insolventieregister (art. I.2.4 lid I).

Verkrijging van een schone lei is niet slechts mogelijk als de insolventie is verzocht door de schuldenaar zelf. Ook als een schuldeiser de insolventverklaring heeft uitgelokt, kan de schuldenaar daarin het verzoek doen om een schone lei (afdeling 6.4). De bewindvoerder dient zich ervan te vergewissen dat de schuldenaar desgewenst tijdig om een schone lei verzoekt (art. 4.2.I lid 2). De beoordeling van het verzoek vindt derhalve niet plaats bij de beslissing over de insolventverklaring, doch op een tijdstip tegen het einde van de insolventie. Dit heeft volgens de Commissie insolventierecht het voordeel dat de beoordeling of het aan de insolventie voorafgegane gedrag van de schuldenaar aan verlening van een schone lei in de weg staat, kan plaatsvinden op een moment dat ook de bevindingen van de bewindvoerder voorhanden zijn. Tegenover dit voordeel staat wel dat het voor schuldenaren onzeker is of zijn inspanningen in de insolventie bekroond zullen worden met een schone lei, hetgeen demotiverend zou kunnen zijn. Persoonlijk acht ik het gewicht van dit bezwaar niet zo groot. ${ }^{162}$ Voorts

I6I. Publicatie van het akkoord kan daardoor achterwege blijven, een aspect dat van groter belang lijkt voor rechtspersonen met een onderneming.

162. De onzekerheid voor de schuldenaar is slechts relatief: hij kan immers in het minnelijk traject al 'sparen' voor de schone lei. Voorts zal ook in het minnelijk traject liquidatie van het vermogen van de schuldenaar kunnen plaatsvinden; in dergelijke gevallen kan de insolventie heel kort duren en komt deze vooral neer op een beoordeling van het gedrag van de schuldenaar. Min of meer in die richting gaan ook de gedachten van Dethmers, Van schuldsanering tot schone lei, p. 195-196. 
zou de loskoppeling van de beoordeling van het gedrag van de schuldenaar en de toelating tot de insolventie kunnen leiden tot een stijging van het aantal insolventies (aldus de NVvR in haar advies over het Voorontwerp). ${ }^{\mathrm{I} 33}$ Maar als daaraan behoefte bestaat, zou de beslissing op het verzoek - althans voor zover het gaat om de goede trouw van de schuldenaar - wat mij betreft ook op een eerder tijdstip in de procedure kunnen worden genomen.

De gronden voor weigering van een schone lei (art. 6.4.2) zijn in een aantal opzichten beperkter dan onder de huidige wet. De schone lei kan worden geweigerd indien:

- minder dan tien jaar tevoren reeds een schone lei is toegekend (een afgewezen schone lei staat daaraan dus niet in de weg);

- de schuldenaar t.a.v. het ontstaan of onbetaald laten van zijn schulden een zodanig ernstig verwijt gemaakt kan worden dat inwilliging van het verzoek onaanvaardbaar zou zijn;

- hij toerekenbaar is tekortgeschoten inde naleving van zijn uit de insolventie voortvloeiende verplichtingen, tenzij de tekortkoming gezien haar bijzondere aard of geringe betekenis buiten beschouwing dient te blijven.

De onaanvaardbaarheidsnorm dient volgens de toelichting terughoudend te worden toegepast, hetgeen tegen de achtergrond van de kritiek van de Commissie op de in haar ogen te strenge wsnp, niet verbaast.

De schone lei betreft niet alleen de onvoldaan gebleven insolventievorderingen, doch mede de onvoldaan gebleven boedelvorderingen (art. 6.4.I lid I). Tegenover deze extra bescherming van de schuldenaar staat dat onvoldaan gebleven salaris van de bewindvoerder in het Voorontwerp ten laste kan komen van de Staat (art. 6.I.2). De vorderingen waarop de schone lei niet van toepassing is, zijn vergelijkbaar met die in de huidige regeling. ${ }^{164}$ Toegevoegd zijn vorderingen, in de beschikking aangewezen, waarvan het ontstaan aan de schuldenaar ernstig verweten kan worden en waarvan verval van afdwingbaarheid, gezien de aard van de vordering, onaanvaardbaar zou zijn (art. 6.4.3 lid I onder a). Hier kan met name gedacht worden aan letselschadevorderingen.

Terugdringing van rechterlijke bemoeienis is in het Voorontwerp ook gezocht door middel van een regeling voor 'schuldbegeleiding na insolventie' (afdeling 7.3). De gedachte is dat als de schuldenaar op het tijdstip dat wordt beslist op het verzoek om een schone lei, zich nog geen drie jaar voldoende heeft ingespannen voor zijn schuldeisers, deze termijn kan worden volgemaakt buiten insolventie, mits de schuldenaar wordt bijgestaan door een door de rechter benoemde 'schuldbegeleider'. Hoewel een voordeel van deze benadering is dat de schuldenaar niet langer dan

I63. Voorspellingen van werklast zijn in het kader van de wsnp totnogtoe tamelijk onbetrouwbaar gebleken. Dit effect zal naar mijn verwachting bescheiden zijn, zeker als de uitkomst van de beoordeling van het gedrag voor de schuldenaar door het engere criterium van art 6.4.2 onder b voorspelbaarder zal zijn dan thans.

I64. Ten aanzien van strafrechtelijke geldboetes (art. 6.4.3 lid I onder b) wordt in de toelichting vermeld dat het slechts gaat om boets uit overtredingen, maar in de tekst komt dat niet tot uitdrukking. 
nodig de beschikking over zijn vermogen moet ontberen, is het voornaamste doel van de regeling het beperken van rechterlijke betrokkenheid. Acht men dat van minder belang, bijvoorbeeld omdat de rechtbanken hun zaken inmiddels weer op orde hebben, dan zal de regeling wellicht minder aanspreken. Dat geldt zeker als men de bemoeienissen van de rechter-commissaris juist van groot belang acht om de schuldenaar 'bij de les te houden'. ${ }^{165} \mathrm{Ik}$ wil op deze plaats verder niet te diep ingaan op deze regeling. Ik volsta met vermelding dat in de inspanningstermijn na insolventie enige bijzondere regels gelden voor beslag en executie. Op een aantal vermogenbestanddelen kan geen beslag worden gelegd, zoals op het vrij te laten bedrag van de inkomsten van de schuldenaar en op al hetgeen de schuldbegeleider voor de schuldenaar bewaart of doet bewaren (art. 7.3.4 lid 3). Beslagen op andere goederen zijn wel mogelijk, doch slechts met conservatoire werking, waarbij zij bovendien van rechtswege mede strekken tot afgifte aan de schuldebegeleider. De schuldbegeleider is gerechtigd om het beslagene onder zich te nemen (art. 7.3.4 lid 4). Uiteindelijk dient de schuldbegeleider alles wat hij van de schuldenaar onder zich heeft te verdelen onder de schuldeisers, waaronder ook eventuele nieuwe schuldeisers. ${ }^{166}$ Dit alles kan men opvatten als bijzondere vorm van bewind (saneringsbewind). Ook kan men er een soort moratorium in zien. Ik heb mij afgevraagd of elementen daaruit niet ook van nut zouden kunnen zijn in de minnelijke fase voorafgaand aan de insolventie.

\section{Io Afsluiting}

Naar mijn overtuiging scoort de Nederlandse regeling voor schuldsanering van natuurlijke personen in het licht van de in paragraaf 2 uiteengezette basisprincipes heel behoorlijk. Ik maak daarover enkele opmerkingen.

Zo vormt titel III van de Faillissementswet, om te beginnen met het eerste principe, een volledige erkenning van het maatschappelijk belang om natuurlijke personen met problematische schuldsituaties te hulp te schieten. Met de wsnp heeft de maatschappij zich de problemen van schuldenaren aangetrokken. En dat niet alleen: de politieke discussie over de maatregelen van 2008 hebben duidelijk gemaakt dat de bereidheid bestaat om zo nodig ook andere maatregelen te nemen om de sociale gevolgen van problematische schulden op te vangen. De aandacht is daarbij deels verschoven naar het minnelijk traject, waarvan men inziet dat versterking niet slechts verwacht kan worden van een 'stok achter de deur'-effect van de wettelijke regeling.

Voor het maatschappelijk draagvlak van de wsnp is van belang dat niet alle schuldenaren zomaar worden toegelaten, ongeacht hoe hun schuldenlast is ontstaan. Ik heb er geen moeite mee dat hierbij bokken van schapen moeten worden gescheiden. Wel dient in het oog te worden gehouden dat het minnelijk en het wettelijk traject een tweeluik vormen, en dat te strenge toelatingseisen in de wsnp de effectiviteit en

I65. Dat is het bezwaar van Jongeneel, 'De inspanningstermijn na insolventie'.

I66. Voor het fixatiebeginsel is immers na afloop van de insolventie geen ruimte meer. 
samenhang van het geheel onder druk zetten. Bij de thans sterk dalende aantallen toelatingen, blijft immers een groeiende groep schuldenaren aangewezen op het minnelijk traject. De hardheidsclausule in art. 288 lid 3 Fw makt duidelijk dat aan het belang van toekomstperspectief zwaarder gewicht kan toekomen dan aan een digitale indeling van al of niet te goeder trouw geweest zijn. Bokken en bokjes hoeven dus niet over één kam te worden geschoren.

Ook het basisprincipe van de fresh start staat niet meer ter discussie. De mogelijkheid van een schone lei voor schuldenaren is een vaste verworvenheid. Niet als een joker die kan worden ingezet als de druk van schuldeisers te hoog is geworden, maar als het sluitstuk van een zware procedure die doorlopen moet worden om de schone lei te 'verdienen'. Wie de politieke discussie over de schuldenproblematiek en over de wsnp volgt, weet dat de centrale doelstelling bestaat in het bevorderen dat op een verantwoorde manier zoveel mogelijk minnelijke schuldregelingen tot stand komen en, waar dat niet mogelijk blijkt, het bieden van een reëel alternatief om in een gerechtelijke procedure te komen tot sanering van schulden. Het schuldeisersbelang - hoe belangrijk ook - staat in de politiek niet voorop. In het Voorontwerp-Insolventiewet had daarmee in de bepalingen over de strekking van de insolventieprocedure nadrukkelijker rekening gehouden kunnen worden.

Wie een nieuwe start wil maken, moet er klaar voor zijn. Het heeft niet zoveel zin om schulden kwijt te schelden aan mensen met een gat in de hand. Het perspectief van een schone lei mag voorbehouden worden aan diegenen van wie aannemelijk is dat zij de verplichtingen, verbonden aan de schuldsaneringsregeling, zullen kunnen nakomen.

De Nederlandse schone lei kent enkele uitzonderingen. Daarmee steekt Nederland internationaal niet ongunstig af. Toch aarzel ik over de gedetailleerde uitzonderingen voor strafrechtelijk getinte (rest)vorderingen, terwijl een schadevergoedingsvordering ter zake van letselschade niet van de schone lei kan worden uitgezonderd (behalve wanneer zij door de benadeelde eerst aanhangig is gemaakt bij de strafrechter). Een mogelijkheid voor de rechter om specifieke vorderingen buiten de schone lei te laten, zoals opgenomen in het Voorontwerp, spreekt mij aan.

Als men kritisch wil zijn over de Nederlandse benadering van problematische schulden, kan die kritiek in elk geval niet inhouden dat de partij-autonomie te weinig aandacht geniet. De voorkeur voor eigen oplossingen van partijen, voor het minnelijk traject derhalve, is welhaast axiomatisch. De wsnp is steeds gericht geweest op het 'versterken' van het minnelijk traject. Daarbij stond tot 2008 voorop dat de verhoudingen tussen partijen in het minnelijk traject als zodanig bezwaarlijk gereguleerd konden worden (i.t.t. de schuldhulpverlening als zodanig): hooguit kon de wsnp als 'stok achter de deur' indirect van invloed zijn op de door partijen zelf te maken keuzes. Met de roep om een moratorium in het minnelijk traject gaat men verder: hier lijkt een inhoudelijke regulering van de verhoudingen tussen partijen aan de orde. Misschien dat dit goed kan werken. Maar dan wel door middel van een inperking van de partij-autonomie. Ook het akkoord buiten insolventie, zoals voorgesteld in het Voorontwerp-Insolventiewet, houdt een nuancering in van de individuele partij-autonomie, doordat individuele schuldeisers kunnen worden gebonden als de meerderheid instemt met het akkoord. Maar daarbij is ten minste nog sprake van partij-autonomie op groepsniveau, hetgeen de voorkeur geniet boven een rech- 
terlijke bevoegdheid om minnelijke regelingen op te leggen, los van enige stemming.

Van rechterlijke betrokkenheid (het vierde basisprincipe) is in de schuldsaneringsregeling natuurlijke personen ruimschoots sprake. Zij vormde lange tijd de achilleshiel van de regeling, en misschien nog wel. Ik was persoonlijk onder de indruk van de klachten, geuit door insolventierechters enige jaren geleden, dat de wet onwerkbaar zou zijn. De geluiden thans, dat 'de machine draait' zijn weliswaar verheugend, maar stellen mij toch niet helemaal gerust. Zoveel is er in $2008 \mathrm{nu}$ ook weer niet veranderd, ook volgens rechters niet. De wsnp is nog steeds een wat logge, complexe regeling, die duidelijke kansen lijkt te bieden voor vereenvoudiging. Uiteindelijk zou dat de kwaliteit van het saneringstraject ten goede moeten komen. Of daarbij zo ver gegaan kan worden dat een natraject wordt gecreëerd met sterk verminderde rechterlijke betrokkenheid - zoals in het Voorontwerp - zal de tijd moeten leren.

Aan het domino-effect dat zich kan voordoen als de insolventie van de schuldenaar ook anderen in moelijkheden brengt, is in de Nederlandse situatie weinig aandacht besteed. Uitgangspunt is dat de schone lei een strikt individuele zaak is, die niet ten voordele strekt van borgen of (andere) medeschuldenaren, zelfs niet van echtgenoten. Dit uitgangspunt lijkt mij ook juist. Niet de schone lei van de schuldenaar brengt anderen in moeilijkheden, maar zijn insolventie.

De schuldsaneringsregeling biedt de schuldenaar een streng, maar zeker geen onmenselijk regime. Aan de schuldenaar wordt een maandelijks bedrag gelaten, dat hoger is dan de beslagvrije voet. Ontruiming van de woning wegens de opgelopen huurachterstand is niet aan de orde, evenmin als afsluiting van gas, licht en water. Zelfs pensioenvoorzieningen blijven in stand. Voor het overige wordt de boedel tegeldegemaakt en moet er gewerkt worden of werk gezocht worden ten behoeve van de schuldeisers. Deze inspanning van de schuldenaar is volkomen op haar plaats. De schuldenaar dient zijn schulden zoveel mogelijk af te lossen en, ook als aflossen er niet inzit, in elk geval van zijn problemen te leren. Van belang is wel dat de schuldenaar zo nodig daadwerkelijk begeleid wordt naar gedragsverandering. Als de schuldenaar budgetbeheer nodig heeft, zou die ook in het wettelijk traject mogelijk moeten zijn. De wsnp biedt daarvoor zelf weinig ruimte.

De schuldsaneringsregeling gaat uit van een termijn van drie jaar inspanning ter aflossing van schulden. Dat is in beginsel een alleszins redelijke termijn. Vallen zaken tegen en slaagt de schuldenaar er bijvoorbeeld tijdelijk niet in om aan zijn verplichtingen te voldoen, dan is een verlenging mogelijk, tot ten hoogste vijf jaar. Deze termijn is lang voor de schuldenaar, maar daarmee nog niet onredelijk. Fraai vind ik de mogelijkheid dat als een schuldenaar duidelijk niet in staat zal zijn enig (verder) positief saldo te genereren, de duur van de regeling kan worden beperkt, zij het niet voordat een jaar is verstreken sinds de toepassing van de regeling is aangevangen.

De schuldeiser zou volgens het achtste principe (geen stigma) na afloop van de schuldsanering geen beperkingen op grond van zijn verleden dienen te ondervinden. In paragraaf 2 vermeldde ik al dat dit onderwerp geen bijzondere aandacht zou krijgen. Stigmatisering betekent dat personen een mindere behandeling krijgen op grond van criteria die dat niet zonder meer rechtvaardigen. Waar in Nederland gesproken wordt van een bijzondere behandeling voor mensen met schulden, is dat 
in de sfeer van bescherming tegen overcreditering. Kredietregistratie strekt in de eerste plaats tot bescherming van de schuldenaren.

Ook op het punt van de kosten voldoent de schuldsaneringsregeling naar mijn mening aan de daaraan te stellen eisen. Aan het verzoekschrift tot toelating zijn als zodanig geen kosten verbonden. De vergoeding van de bewindvoerder komt uiteraard wel ten laste van de boedel, doch slechts ten dele. Doordat de Staat subsidie verstrekt aan bewindvoerders, wordt voorkomen dat de schuldenaar na afloop van de schuldsanering ondanks de schone lei met (rest)boedelschulden blijft zitten.

Al met al mag de wsnp een succes worden genoemd, maar niet een vanzelfsprekend succes en zeker geen garantie voor de toekomst. Grondig onderzoek naar de duurzaamheid van een schone lei ontbreekt nog (al biedt de tweede Wsnp monitor voorzichtige positieve indicaties). En verder presteren het minnelijk traject en het wettelijk traject samen nog steeds niet indrukwekkend, en dat is toch eigenlijk waar het om zou moeten gaan. Daarom blijft het van belang open te staan voor verdere verbeteringen.

Op welke punten zie ik vooral ruimte voor verbetering?

- In de eerste plaats vind ik de goede trouw-toets, gelet op het centrale belang voor de schuldenaar, eigenlijk te onbepaald, terwijl de verhouding tot de hardheidsclausule de zaak niet helderder maakt. Verder vind ik onduidelijk wat de betekenis is van het meewegen van alle omstandigheden van het geval in de beoordeling van de goede trouw, als tegelijkertijd benadrukt wordt dat ontbreken van goede trouw imperatief tot afwijzing dient te leiden. Is het dan niet beter om te kiezen voor een terughoudender norm, zoals in het Voorontwerp?

- De regeling is complex vormgegeven, vooral waar het gaat om de verhouding tot faillissement en bij de bepalingen over het einde van de schuldsanering. Uit het Voorontwerp blijkt naar mijn mening - even los van de precieze uitwerking ten aanzien van bijvoorbeeld het moment van beoordeling van de goede trouw van de schuldenaar - dat een geïntegreerde procedure systematisch grote voordelen biedt. Die integratie hoeft daarbij niet te betekenen dat de strekking van de regeling ten aanzien van natuurlijke personen niet meer, of vooral, gericht kan zijn op het saneringsbelang in plaats van op het belang van de gezamenlijke schuldeisers.

- De verhouding tot het minnelijk traject blijft problematisch, deels als gevolg van het feit dat dat traject inhoudelijk niet is gereguleerd. Er is veel werk gemaakt van het succesvoller maken van het minnelijk traject, onder meer door convenanten met institutionele schuldeisers, zoals het Centraal Justitieel Incassobureau. Ook de regelingen van art. 287a $\mathrm{Fw}$ (voorlopige voorzieningen in 'bedreigende situaties') en $287 \mathrm{~b}$ Fw ('dwangakkoord') kunnen leiden tot meer minnelijke schuldregelingen. Naar mijn oordeel is de juridische vormgeving van beide regelingen niet ideaal en biedt het Voorontwerp aanknopingspunten voor verdere verbetering. 